UNIVERSIDADE DE SÃO PAULO

ESCOLA DE ENFERMAGEM

HELOISA DA VEIGA COELHO

A ATENÇÃO AO USUÁRIO DE DROGAS NA ATENÇÃO BÁSICA:

ELEMENTOS DO PROCESSO DE TRABALHO EM

UNIDADE BÁSICA DE SAÚDE

SÃO PAULO

2012 

HELOISA DA VEIGA COELHO

\title{
A ATENÇÃO AO USUÁRIO DE DROGAS NA ATENÇÃO BÁSICA: ELEMENTOS DO PROCESSO DE TRABALHO EM UNIDADE BÁSICA DE SAÚDE
}

\author{
Dissertação apresentada à Escola de \\ Enfermagem da Universidade de São \\ Paulo para obtenção do Título de Mestre \\ em Enfermagem \\ Área de Concentração: \\ Enfermagem em Saúde Coletiva \\ Orientadora: \\ Prof ${ }^{a}$. Drª . Cássia Baldini Soares
}

SÃO PAULO 

AUTORIZO A REPRODUÇÃO E DIVULGAÇÃO TOTAL OU PARCIAL DESTE TRABALHO, POR QUALQUER MEIO CONVENCIONAL OU ELETRÔNICO, PARA FINS DE ESTUDO E PESQUISA, DESDE QUE CITADA A FONTE.

Assinatura:

Data:

Catalogação na Publicação (CIP)

Biblioteca "Wanda de Aguiar Horta"

Escola de Enfermagem da Universidade de São Paulo

Coelho, Heloisa da Veiga

A assistência ao usuário de drogas na atenção básica: elementos do processo de trabalho em unidade básica de saúde que interferem nas práticas / Heloisa da Veiga Coelho. -São Paulo, 2012.

$224 \mathrm{p}$.

Dissertação (Mestrado) - Escola de Enfermagem da Universidade de São Paulo.

Orientadora: Profa. Dra. Cássia Baldini Soares

Área de concentração: Saúde coletiva

1. Atenção primária à saúde 2. Saúde pública

3. Usuários de drogas 4. Transtornos relacionados ao uso de substâncias 5. Pacientes - Cuidados 6. Política de saúde I. Título. 



\section{FOLHA DE APROVAÇÃO}

Nome: Heloisa da Veiga Coelho

Titulo: A atenção ao usuário de drogas na Atenção Básica: Elementos do processo de trabalho em Unidade Básica de Saúde.

Dissertação apresentada à Escola de Enfermagem da Universidade de São Paulo para obtenção do título de Mestre em Enfermagem.

Aprovado em:

Banca Examinadora

Prof.Dr.

Julgamento:

Prof.Dr.

Julgamento:

Prof.Dr.

Julgamento:
Instituição:

Assinatura:

Instituição:

Assinatura:

Instituição:

Assinatura: 



\section{DEDICATÓRIA}

Ao men filho João Pedro, fonte inesgotável de inspiração na luta por um mundo mais justo e solidário para todos.

Atodos os trabalhadores da área da saúde.

Acredito que a concretização do Sus perpassa a luta e participação destes

sujeitos. 



\section{AGRADECIMENTOS}

Aos meus pais, que desde cedo me ensinaram com seus exemplos valores tão caros para mim como justiça, igualdade e solida riedade;

Ao meu irmão Rogério, que sempre esteve ao meu lado, mesmo quando eu ainda não tinha noção da importância desse apoio;

Ao Paulo, companheiro que escolhi para compartilhar a vida, os sonhose as

histórias. Obrigada pela compreensão, pelo apoio incondicional e por não permitir que en desistisse desse sonho, apesar das inumeras vezes que cogitei essa possibilidade;

À professora cássia, grande mestra e amiga que tive o privilégio e a houra de ser minha orientadora, que ampliou bastante a minha forma de recortar a realidade para compreendê-la e me colocon ainda mais d̀ esquerda no mundo;

ÀMaria, meubraço direito Lá em casa;

Aos amigos queridos, que me apoiaram nos momentos solitários e dificeis desse percurso. Em especial à Lú è̀ Tati (que está lá em Brasília, mas bem pertinho de mim sempre); 

Ao grupo de pesquisa "Fortalecimento e Desgaste no trabalho e na vida: bases para a intervenção em Saúde Coletiva", por ser um espaço fértil de reflexão ecrítica no qual tive o privilégio de participar durante toda a trajetória do mestrado e espero continuar participando;

Ao pessoal da Redução de Danos do municipio de Embri, que tanto me ensinam no cotidiano de construção de uma alternativa mais humanae Lúcida de enfrentamento das questões relacionadas aos usuários de drogas;

Aos trabalhadores da UBS Dr. Eduardo Romano Reschilian, que muito contribuiram com este estudo e com minha formação. Em especial à Dra.

Elza, grande amiga e que sempre será a mel hor chefe que en já tive;

A)ú Takahashi (bibliotecária), pela enorme paciência e dedicação;

Aos funcionários da Escola de Enfermagem da USP, em especial ao pessoal da Secretaria de Pós Graduação, pelo carinho e atenção com que acothe nossas dúvidas, angústias e aftições;

Enfim, a todos que de alguma forma fizeram parte da minha históriae contribuiram para que euchegasse até aqui. 



\section{EPÍgRAFE}

Nosso dia vaichegar

Teremos nossa vez

Não é pedir demais:

Querojustica!

Quero trabalharem paz

$\mathcal{N a ̃ o ~ e ́ ~ m u i t o ~ o ~ q u e ~ p e c o ~}$ Eu queroum trabalho honesto

Em vez de escravidão.

Deve haver algum lugar

onde o mais forte não

consegue escravizar

Que não tem chance

De onde vem a indiferença

Temperada a ferro e fogo?

cuem guarda os portões da fábrica?

o céu jáfoi azul, mas agora é cinza. o que era verde aqui já não existe mais.

Quem me dera acreditar

cue não acontece nada

Detantobrincarcom fogo

Que venha o fogo então

Esse ar deixou minha vista cansada $\mathcal{N a d a}$ demais

(Fábrica - Renato Russo) 

Coelho HV. A atenção ao usuário de drogas na Atenção Básica: elementos do processo de trabalho em UBS (dissertação). São Paulo: Escola de Enfermagem da Universidade de São Paulo, 2012.

\section{RESUMO}

O objeto deste estudo são as práticas de Atenção Básica (AB) desenvolvidas nos serviços de saúde voltadas para pessoas e grupos sociais que consomem drogas de forma prejudicial. Este objeto foi recortado a partir do referencial teórico da Saúde Coletiva e se conforma na interface entre as políticas públicas voltadas para a população que faz uso prejudicial de drogas e a realidade concreta dos serviços de saúde. O estudo tem por objetivo geral analisar as práticas voltadas para consumidores problemáticos de drogas na $A B$, a partir do levantamento dessas práticas junto a trabalhadores de uma UBS da região periférica do município de São Paulo. Trata-se de estudo qualitativo, de natureza descritiva e analítica, que se desenvolveu na perspectiva dialético-crítica. A coleta de dados foi realizada a partir de entrevistas semiestruturadas e individuais com 10 trabalhadores de uma UBS mista, ou seja, que atua com a Estratégia de Saúde da Família (ESF) e com o modelo tradicional de produção dos serviços de saúde. As práticas desenvolvidas pelos trabalhadores e direcionadas aos usuários de drogas são analisadas a partir da categoria analítica processo de trabalho, que permite analisar os modos e as dificuldades de operacionalização das políticas públicas nos espaços concretos de produção dos serviços de saúde. Os resultados mostram que: 1) os trabalhadores desenvolvem o processo de trabalho, na perspectiva funcionalista da moderna saúde pública, que compreende o consumo de drogas como doença e considera usuários de drogas como desviantes; 2) as práticas existentes são consideradas frágeis e os trabalhadores valorizam muito a formação técnicoclínica, que em suas opiniões proporcionaria melhores respostas para as demandas relacionadas ao uso de drogas; 3 ) reproduz-se um ciclo infértil de explicação sobre a incapacidade e as sensações de fracasso que tomam conta do discurso de muitos trabalhadores que lidam com demandas 

relacionadas ao consumo prejudicial de drogas; 4) todo o processo de trabalho parece ficar centrado num único elemento, o trabalhador em si, já que os demais elementos não se encontram estruturados para atender a demanda. Pode-se concluir que as formas como se organizam os processos de trabalho na $A B$ e como se estrutura o processo de produção dos serviços de saúde brasileiro dificulta e/ou impede o acesso da população usuária de drogas à rede de atenção à saúde. $A$ AB carece de elementos estruturais inerentes ao processo de produção em saúde, e da dinamicidade interna aos processos de trabalho, que favoreçam a implementação de práticas voltadas aos indivíduos e grupos sociais que usam drogas de forma prejudicial. Este trabalho contribui com a finalidade do estudo de promover denúncia em relação à fragilidade das práticas desenvolvidas na $A B$ frente às desafiadoras e crescentes demandas relacionadas ao consumo de drogas pela população.

Palavras-Chaves: Atenção Primária à Saúde; Saúde Coletiva; Consumo de bebidas alcoólicas; Usuários de drogas; Condições de trabalho; Política de saúde. 

Coelho HV. The attention to drug users in Primary Health Care: elements of the work process in Primary Health Centers (dissertation). São Paulo: School of Nursing of the University of São Paulo, 2012.

\section{ABSTRACT}

The object of this study was the practices developed at Primary Health Care services focused on individuals and social groups who use drugs in a harmful way. The study object derived from the theoretical framework of collective health and was constructed at the interface between public policies focused on the population that uses harmful drugs and the reality of health services. The aim of the study was to analyze the practices towards drug users at Primary Health Care based on a survey of these practices with workers of a Primary Health Center (PHC) in the outskirts of São Paulo. It is a qualitative, descriptive and analytical research developed within a critical-dialectical approach. Data were collected from semi structured interviews with 10 workers of a PHC, which has two different health care models, namely: the Family Health Strategy and the traditional model of primary health services. The practices developed by workers and directed towards drug users were analyzed from the analytical category of the work process, which allows the analysis of the modes and difficulties to operationalizing public policies as practices that take place in the real spaces of the health production process. Results show that: 1) workers develop the work process within the functionalist perspective of the modern public health, which understands drug consumption as a disease and considers users as deviants; 2) the existing practices are actually considered fragile and the workers greatly value technical and clinical training that in their opinions would provide better responses to the demands related to drug use; 3) a cycle of infertile explanation about the incapacity and the feeling of failure of the workers who deal with demands related to drug use is reproduced; 4) the entire work process seems to be focused on a single element, the workers itself since the other elements seem not to be structured. It may be concluded that the ways the work process is organized in the $\mathrm{PHC}$ and how the process of the 

Brazilian primary health services is structured makes it difficult or constitute a barrier for drug users to access the health care network. The PHC lacks structural elements inherent to the health care process and internal dynamics of the work processes that favor the implementation of practices directed towards individuals and social groups who use drugs in a harmful way. The purpose of the study is to report the fragility of the practices developed at the $\mathrm{PHC}$ due to the challenging and increasing demands of drug consumption.

Key words: Primary Health Care; Collective Health; Alcohol Consumption; Drug Abusers; Working Conditions; Health Policy. 



\section{LISTA DE SIGLAS}

$\begin{array}{ll}\text { AB } & \text { Atenção Básica } \\ \text { APS } & \text { Atenção Primária em Saúde } \\ \text { ACS } & \text { Agente Comunitário de Saúde } \\ \text { AMA } & \text { Assistências Médicas Ambulatoriais } \\ \text { ATA } & \text { Auxiliar Técnico Administrativo } \\ \text { CAPS } & \text { Centro de Atenção Psicossocial } \\ \text { CAPS ad } & \text { Centro de Atenção Psicossocial em Álcool e Drogas } \\ \text { CEP } & \text { Comitê de Ética em Pesquisa } \\ \text { CEU } & \text { Centro Educacional Unificado } \\ \text { CLT } & \text { Consolidação das Leis do Trabalho } \\ \text { CT } & \text { Comunidades Terapêuticas } \\ \text { ESF } & \text { Estratégia de Saúde da Família } \\ \text { EUA } & \text { Estados Unidos da América } \\ \text { FMI } & \text { Fundo Monetário Internacional } \\ \text { MJ } & \text { Ministério da Justiça } \\ \text { MS } & \text { Ministério da Saúde } \\ \text { NASF } & \text { Núcleo de Apoio à saúde da Família } \\ \text { NOB } & \text { Normas Operacionais Básicas } \\ \text { ONU } & \text { Organização das Nações Unidas } \\ \text { OS } & \text { Organizações Sociais } \\ \text { PA } & \text { Pronto - Atendimento } \\ \text { PACS } & \text { Programa de Agentes Comunitários de Saúde } \\ \text { PMSP } & \text { Prefeitura Municipal de São Paulo } \\ \text { PS } & \text { Pronto - Socorro } \\ \text { PSDB } & \text { Partido da Social Democracia Brasileira } \\ \text { PSF } & \text { Programa de Saúde da Família } \\ \text { RD } & \text { Redução de Danos } \\ \text { SENAD } & \text { Secretaria Nacional sobre Drogas } \\ \text { SESI } & \text { Serviço Social da Indústria } \\ \text { SMS } & \text { Secretaria Municipal de Saúde } \\ \text { SPDM } & \text { Sociedade Paulista para o desenvolvimento da medicina } \\ \end{array}$





$\begin{array}{ll}\text { SUS } & \text { Sistema Único de Saúde } \\ \text { TCLE } & \text { Termo de Consentimento Livre e Esclarecido } \\ \text { TCM } & \text { Tribunal de Contas do Município } \\ \text { UBS } & \text { Unidade Básica de Saúde } \\ \text { UNISA } & \text { Universidade Santo Amaro } \\ \text { VD } & \text { Visita Domiciliar }\end{array}$





\section{SUMÁRIO}

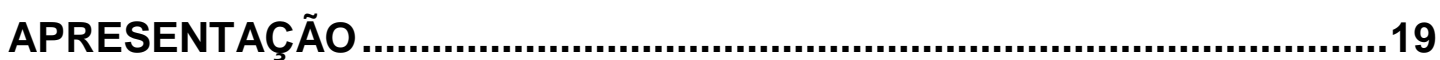

1 INTRODUÇÃO

1.1 A SITUAÇ̃̃O DA AB NO MUNICÍPIO DE SÃO PAULO .............................30

1.2 HISTÓRIA DAS POLÍTICAS NA ÁREA DE DROGAS: REFLEXOS NA

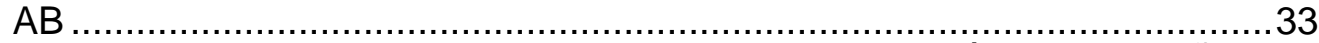

1.3 COMO A AB TRANSITA NA ESFERA DO CUIDADO À POPULAÇÃO USUÁRIA DE DROGAS ................................................................... 44

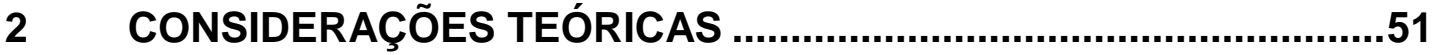

2.1 O FENÔMENO DO CONSUMO DE DROGAS NA CONTEMPORANEIDADE ............................................................52

2.2 TRANSFORMAÇÕES NO PROCESSO DE TRABALHO EM SAÚDE E O IMPACTO NO COTIDIANO DE TRABALHO DA AB ................................65

2.2.1 Crise, Neoliberalismo e Saúde ............................................................65

2.2.2 Repercussões do Neoliberalismo para os trabalhadores de saúde da

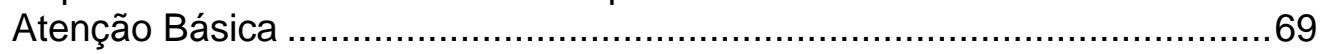

2.2.3 Impactos do Neoliberalismo na produção de saúde na AB ...........................73

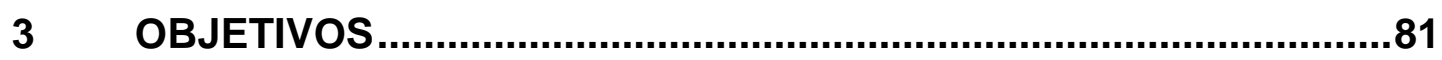

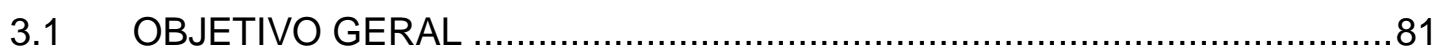

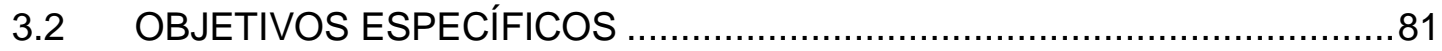

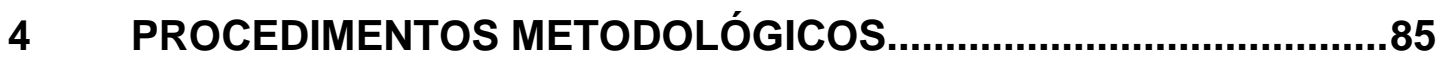

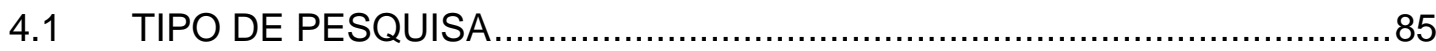

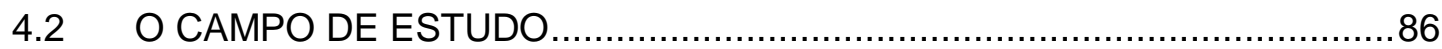

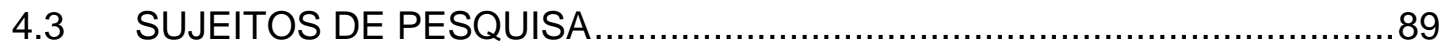

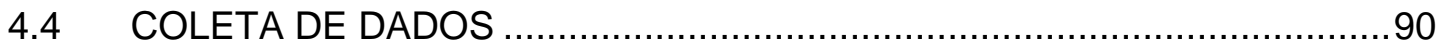

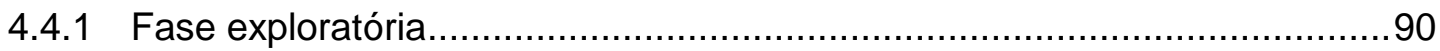

4.4.2 Fase de coleta de dados ....................................................................92

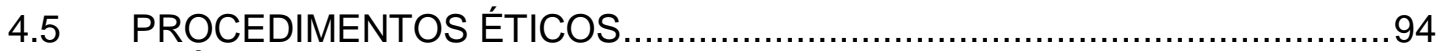

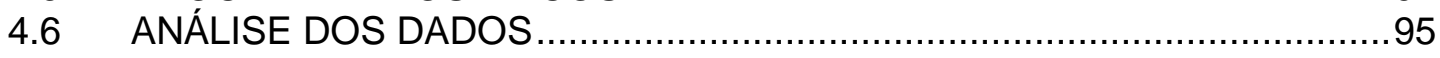

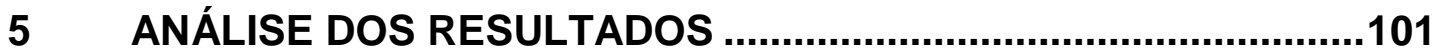

5.1 QUEM SÃO OS SUJEITOS DE PESQUISA? …….............................101

5.2 O QUE HÁ POR TRÁS DA AUSÊNCIA DE DEMANDAS RELACIONADAS AO CONSUMO DE DROGAS NA AB? .........................102

5.2.1 Aspectos que contribuem para a compreensão do fenômeno do consumo de drogas na contemporaneidade por parte dos trabalhadores da $A B$......................................................................................... 103

5.2.2 Processo interrompido: Demandas relacionadas ao consumo de drogas que chegam na $A B$ e não são reinterpretadas como necessidades de saúde pelos trabalhadores

5.3 AS PRÁTICAS PELO OLHAR DO TRABALHADOR: PRÁTICAS PROTOCOLARES $x$ PRÁTICAS QUE AMPLIAM O OBJETO DA

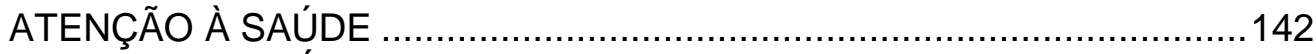

5.4 A REDE DE SAÚDE MENTAL PELO OLHAR DO TRABALHADOR: A INEFICÁCIA DO MODELO DE ATENÇÃO BIOMÉDICO E PRIVATISTA NA AB

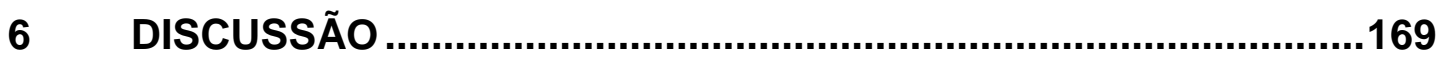

7 CONSIDERAÇÕES FINAIS ..........................................................195

7.1 ALGUMAS CONSIDERAÇÕES SOBRE POSSÍVEIS ENCAMINHAMENTOS 



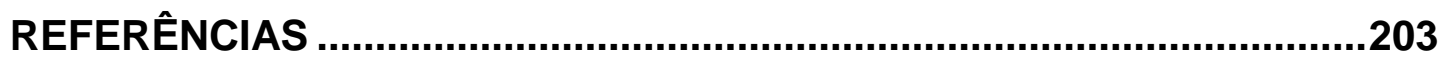

ANEXOS

ANEXO 1

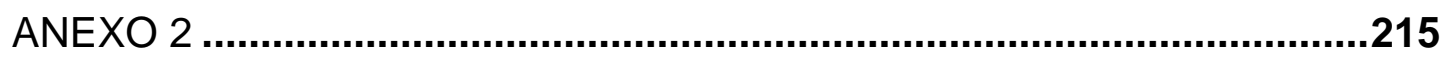

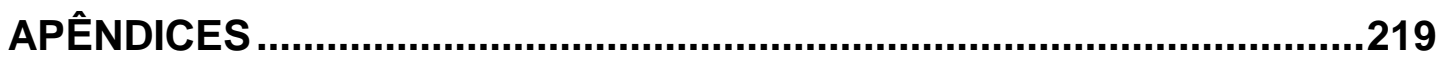

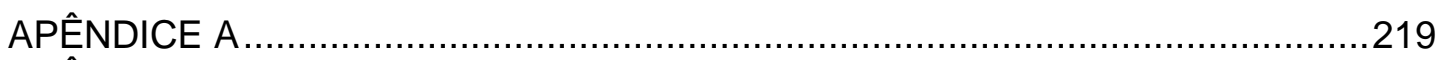

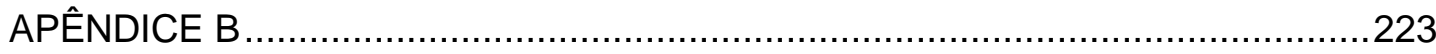



- Apresentasãa 



\section{APRESENTAÇÃO}

A motivação que me trouxe de volta à universidade e consequentemente ao desenvolvimento deste estudo remonta a toda minha trajetória profissional desde a graduação, passando pelo Programa de Saúde da Família (hoje denominado de Estratégia de Saúde da Família), pelo Programa de Redução de Danos e pela docência.

A universidade (especialmente a pública) é um espaço privilegiado para a produção de conhecimento, mas, no meu entendimento, ela não deve deter-se apenas neste aspecto. Deve sim abrir-se para a sociedade (pensando aqui na responsabilidade social das universidades) por ter capacidade de promover reflexões, questionamentos sobre os paradigmas hegemônicos que norteiam as políticas públicas no país e também por poder denunciar as formas equivocadas de se pensar e fazer saúde.

A minha participação num projeto de pesquisa da Universidade de Brasília intitulado "Redução de Danos: Uma questão de saúde e Cidadania" me aproximou do tema das drogas na contemporaneidade e essa aproximação mostrou o quanto minha formação foi insuficiente para dar conta de analisar esse fenômeno com um olhar mais ampliado e livre das amarras do preconceito e do estigma.

É interessante notar que durante os quatro anos de experiência no Programa de Saúde de Família eu não tinha clareza para perceber o quanto as questões relacionadas ao uso e abuso de drogas eram deixadas de lado no cotidiano atribulado do meu trabalho na Atenção Básica, mesmo tratando-se de questão que permeava muitas das demandas que chegavam até mim. Por conta do medo, do preconceito e da falta de uma formação que me proporcionasse meios e instrumentos adequados para ampliar o 
objeto de minhas práticas e para lidar com esta questão tão complexa, eu preferia me abstrair, esquecer, deixar passar tal problemática, lidando apenas com aquilo que eu tinha possibilidade de, a partir dos instrumentais de que dispunha, mudar, transformar ou simplesmente melhorar parcialmente. Assim, de forma fragmentada e dissociada da realidade e das formas de viver das pessoas atendidas no serviço, eu ia produzindo saúde.

Nessa época eu busquei por formação na área de álcool e drogas, pois esta era uma questão que já me inquietava. Porém, em todos os espaços de formação que busquei, não havia 0 aprofundamento necessário para compreender a trama social que envolve o fenômeno do uso de drogas na contemporaneidade.

As indagações que surgiram a partir da minha aproximação com o paradigma da Redução de Danos tornaram-se mais complexas e me fizeram buscar espaços de formação que me permitisse ampliar o referencial teórico acerca deste fenômeno para compreendê-lo em toda a sua amplitude.

Após um período de estudos, reflexões, incursões ao campo (agora com um olhar de pesquisador e não apenas de profissional de saúde) muitos outros questionamentos surgiram e estes recaiam quase sempre sobre os desdobramentos das políticas públicas nos serviços de saúde, nas práticas cotidianas dos trabalhadores e finalmente no atendimento das demandas relacionadas ao consumo de drogas.

Com essa bagagem e muitas transformações na minha própria maneira de ver a vida e o fenômeno do consumo de drogas, acabei por voltar os olhos para a Atenção Básica (lócus fundamental na minha trajetória) e dessa forma observar como as demandas relacionadas ao consumo de drogas chegam neste nível de atenção e como os trabalhadores compreendem e lidam com tais demandas.

$\mathrm{O}$ objeto de pesquisa foi dessa forma se delineando a partir da minha experiência profissional, somado à bagagem teórica que fui acumulando ao longo da minha trajetória, especialmente no 
momento que ingressei no programa de pós-graduação. 0 referencial teórico utilizado foi amplamente enriquecido com as discussões e reflexões sobre modelos de atenção, atendimento da população que faz uso de drogas em São Paulo e políticas públicas, realizadas no grupo de pesquisa Fortalecimento e desgaste no trabalho e na vida: bases para a intervenção em Saúde Coletiva, no Fórum Intersetorial de Drogas e Direitos Humanos e na Escola de Redutores de Danos do município de Embú. 

- Pntroducãa 



\section{INTRODUÇÃO}

O objeto deste estudo são as práticas desenvolvidas nos serviços de saúde da Atenção Básica $(A B)$ voltadas para pessoas que fazem uso de drogas de forma prejudicial. Este objeto se conforma na interface entre as políticas públicas voltadas para a população que faz uso de álcool e outras drogas e a realidade concreta dos serviços de saúde de $A B$ que, na organização do sistema de saúde brasileiro, são considerados porta de entrada.

$A A B$ é definida pelo Ministério da Saúde (MS) como um conjunto de ações de saúde que englobam a promoção, prevenção, diagnóstico, tratamento e reabilitação. É desenvolvida através do exercício de práticas gerenciais e sanitárias, democráticas e participativas, sob a forma de trabalho em equipe, dirigidas a populações de territórios bem delimitados, pelas quais assumem responsabilidade. Utiliza tecnologias de elevada complexidade e baixa densidade, que devem resolver os problemas de saúde das populações (de maior frequência e relevância). É o contato preferencial dos usuários com o sistema de saúde. Orienta-se pelos princípios da universalidade, acessibilidade, continuidade, integralidade, responsabilização, humanização, vínculo, equidade e participação social (Brasil, 2006).

Nota-se, entretanto, que apesar da Política Nacional de $A B$ apresentar esses equipamentos de saúde como estratégicos para a organização dos sistemas locais de saúde, estes não conseguem operacionalizar de forma adequada todas as funções que são atribuídas a esse nível de atenção, não concretizando os princípios que norteiam a organização desses serviços, mesmo com a sua reestruturação, a partir da década de 1990 e estímulo ao desenvolvimento de estratégias de fortalecimento desse nível de atenção nos anos 2000 (Favoreto, Camargo Jr, 2002; Scherer et al, 
2005; Giovanella et al, 2009; Sousa, Hamann, 2009; Heimann et al, 2011).

A operacionalização do Sistema Único de Saúde (SUS) parte da reestruturação da $A B$ que iniciou-se concretamente a partir das Normas Operacionais Básicas (NOB) de 1993 e 1996 elaboradas pelo MS. Muitos interesses estavam em jogo no momento da elaboração destas normas operacionais e houve confronto desses interesses em diversos espaços (Arretche, 2005). Tais normas implementam a descentralização da assistência à saúde e redefinem o papel de cada ente da federação (federal, estadual e municipal) no que tange à assistência à saúde da população, determinando a gradual responsabilização dos municípios na prestação dessa assistência (MS, 1993; MS, 1996; Heimann, Mendonça, 2005). Outros documentos normativos foram implementados pelo Ministério da Saúde (MS) ao longo da primeira década do século XXI com intuito de vencer obstáculos e desafios impostos pela realidade brasileira para o desenvolvimento e fortalecimento da $A B$, que passou a ter papel estratégico de reordenamento do sistema de saúde brasileiro e expansão do acesso à saúde, a despeito do financiamento ainda pífio nesse nível de atenção e todos os enormes problemas que enfrenta na atualidade para se consolidar $\mathrm{e}$ promover uma mudança real no modelo de atenção do país (Favoreto, Camargo Jr, 2002; Scherer et al, 2005; Giovanella et al, 2009; Sousa, Hamann, 2009; Heimann et al, 2011).

Embora haja avaliações discordantes, a leitura que se persegue neste estudo é a de que a reestruturação da $A B$, principalmente a partir da implantação do Programa de Saúde da Família (PSF), atual Estratégia de Saúde da Família (ESF), obstaculiza a implementação dos princípios e diretrizes do SUS, principalmente no que concerne à universalidade, integralidade e igualdade de acesso. Dessa forma põe em questão a Constituição brasileira que considera a saúde um direito de todos os cidadãos e que responsabiliza o Estado pela garantia desse direito. 
Da forma como está organizada a $A B$ hoje, mesmo com a implantação da ESF, ela não garante atendimento universal e integrado, mas 0 atendimento de algumas necessidades, determinadas em nível central, de grupos específicos, sendo estes grupos específicos pertencentes às classes sociais subalternas, que não possuem condições de comprar a assistência à saúde no mercado (via planos privados de saúde). Os grupos específicos são: crianças menores de dois anos, mulheres durante a gestação e puerpério, hipertensos, diabéticos, tuberculosos e hansenianos (Favoreto, Camargo Jr, 2002; Scherer et al, 2005; Soares, 2007; Calipo, Soares, 2008).

A AB como foi reestruturada, e, particularmente a ESF, substitui o direito universal à saúde pela atenção às necessidades e carências de grupos particulares (Calipo, Soares, 2008).

As ações desenvolvidas na $A B$ são criticadas por Soares (2007), que acompanha tendência crítica às ações prioritárias da ESF, considerando-as parte de um "pacote mínimo" de ações, definido por organismos internacionais (como o Fundo Monetário Internacional/FMl e Banco Mundial), que emprestam dinheiro para o país se este se comprometer a gastar o mínimo possível com políticas sociais (incluindo aí a área da saúde). São esses organismos que de primeira instância determinam onde e como o dinheiro deverá ser investido. São eles também que definem o que será contemplado neste "pacote mínimo" da saúde.

Embora se postule o desenvolvimento de práticas voltadas para as pessoas que vivem nos territórios de abrangência de Unidades Básicas de Saúde (UBS), as ações em saúde na $A B$ deixam de considerar as realidades locais e as necessidades da coletividade. Este processo de reestruturar a $A B$ a partir de ações programáticas que não consideram as realidades locais acaba por despolitizar os serviços de saúde, os trabalhadores que atuam nestes espaços e a população que faz uso do mesmo. Estes sujeitos (trabalhadores e usuários dos serviços) não refletem e nem se 
aprofundam no conhecimento da realidade local (formas de trabalhar e de viver da população do território, bem como as formas de adoecer). As condições de vida e de saúde da população não são tomadas no momento de se construir as intervenções em saúde, não há participação de todos os sujeitos imbricados no processo de produção dos serviços de saúde e consequentemente não há construção de ações a partir das necessidades de saúde (produzidas socialmente) dos diferentes grupos sociais que vivem no território de abrangência das UBS. Tais ações são elaboradas em nível central sem a participação destes sujeitos. Estes recebem passivamente as determinações que o Estado (influenciado pelos interesses capitalistas de organismos internacionais) define como prioritário (Campos, Mishima, 2005; Salum, Queiroz, 2005; Scherer et al, 2005; Calipo, Soares, 2008).

\begin{abstract}
Contemporaneamente estamos retrocedendo à satisfação das necessidades através de políticas de compensação. Já não se propõe a dignidade do viver como componente da vida em sociedade e na qual o acesso à plena assistência à saúde é um dos seus requisitos.

Em síntese há uma naturalização das desigualdades socio-econômicas. É natural que as pessoas sejam pobres ou ricas e, que as ricas paguem suas despesas com saúde, enquanto que as pobres recebam do Estado e da caridade alguns tipos de atendimento. A desigualdade é algo natural e não fruto da ação do homem, da forma de organização da sociedade, que se apropria de modo particular da riqueza produzida socialmente (Calipo, Soares, 2008, p.130).
\end{abstract}

Desde a consolidação do SUS a $A B$ foi tomada como eixo norteador da reorganização do sistema de saúde brasileiro. Neste panorama a $A B$ se coloca como primeiro nível de atenção e sua expansão e reorganização é considerada uma estratégia fundamental para a substituição do modelo de atenção no país (Heiman, Mendonça, 2005; Giovanella et al, 2009; Sousa, Hamann, 2009; Heimann et al, 2011). Houve uma expansão da $A B$ no país acompanhando a expansão da ESF e, por conseguinte, ocorreram alterações no processo de produção de serviços de saúde. Porém, 
esta reorganização não conseguiu romper com a lógica hegemônica de produção destes serviços, lógica esta pautada nas demandas individuais, no modelo clínico, biomédico e centrado no agravo/doença e não no conhecimento das necessidades da população e das suas condições de vida (formas de trabalhar e de viver) e de saúde (Favoreto, Camargo Jr, 2002; Campos, Mishima, 2005; Scherer et al, 2005; Queiroz, Salum, 1996).

A ESF foi formulada a partir da década de 90 e constitui um modelo de organização da atenção no âmbito primário ${ }^{1}$, que convive com outros modelos dentro do SUS. A forma como se organiza esse modelo denuncia que, apesar do avanço que o SUS trouxe para a garantia de direitos sociais, ele não conseguiu romper com o modelo de abordagem seletiva de atenção primária, característico de países de capitalismo periférico como os países da América Latina, preconizado pelas agências multilaterais e fortemente identificado com a medicina curativa (Giovanella et al, 2009; Heimann, Mendonça, 2005).

Apesar disso, essa estratégia foi intencionalmente eleita como prioritária para o fortalecimento e organização da AB (Brasil, 2006).

Atualmente, com a hegemonia do pensamento neoliberal e a influência externa na organização do sistema de saúde do país, o SUS vive um impasse, sendo diariamente atacado em seus princípios e diretrizes. Sua operacionalização se configura como um projeto de "contra-reforma" e vivemos um embate entre os defensores de um sistema público de saúde universal e integral, em que a saúde é considerada um direito de cidadania e aqueles que acreditam que o sistema público de saúde deve ser fragmentado e direcionado para aqueles que não possuem condições de comprar a

1 Os termos Atenção Básica (AB) e Atenção Primária em Saúde (APS) estão sendo utilizados, no âmbito das políticas públicas, como sinônimos. Para Giovanella et al (2009), na década de 90, a concepção de APS no Brasil foi renovada, a partir da regulamentação do SUS, e para diferenciar-se da concepção seletiva da APS, hegemônica até então, cunhou-se na política de saúde brasileira o termo Atenção Básica. Porém, analisando a evolução da $A B$ no Brasil percebese que ela não rompeu definitivamente com a característica não abrangente da APS. 
assistência à saúde no mercado (Noronha, Soares, 2001; Heimann, Mendonça, 2005; Bravo, Menezes, 2007; Rezende, 2007).

A lógica que se imprime hoje na estruturação do processo de produção dos serviços de saúde na $A B$ é mesmo a do "pacote mínimo" (condizente com o projeto de mercadorização da saúde), contrapondo-se às conquistas históricas na área da saúde, pois não proporciona uma mudança estrutural nos fatores que condicionam e influenciam os modos de trabalhar, viver e adoecer da população (Salum, Queiroz, 2005; Soares, 2007).

\subsection{A SITUAÇÃO DA AB NO MUNICÍPIO DE SÃO PAULO}

A década de 1990 no estado de São Paulo e particularmente no município de São Paulo foi fundamental para a expansão das Organizações Sociais (OS) e concretização do projeto neoliberal na área da saúde. Na verdade, São Paulo foi o primeiro laboratório de experiências de privatização da saúde no Brasil. Segundo Seixas (2003):

(...) OS são entidades de direito privado, qualificadas pelo poder executivo do Estado para o estabelecimento de compromisso de execução de atividades em áreas de interesse público (ensino, pesquisa, proteção e preservação do meio-ambiente, cultura e saúde). Habilita-se a receber dotação orçamentária do Estado, garantidos 0 cronograma de desembolsos da administração de seus bens e dos equipamentos do Estado, necessários ao exercício de suas atividades, durante a vigência do contrato de gestão, pelo qual são preconizadas metas de desempenho que assegurem a extensão e a qualidade dos serviços prestados ao público. O Estado qualificará as OS como associações civis sem fins lucrativos (Seixas PHD, 2003, p. 33).

O processo de privatização da saúde em São Paulo começou com a contratação pelo governo estadual (na gestão de Mário Covas/PSDB) de algumas OS para gerenciamento de hospitais na região metropolitana de São Paulo (áreas periféricas) como parte do 
Plano Metropolitano de Saúde, financiado pelo Banco Mundial já na década de 1980 (Seixas, 2003; Rezende, 2007).

$A$ investida das $O S$ sobre equipamentos da $A B$ no município teve início com o projeto de implantação e expansão da ESF na década de 1990. As duas primeiras OS que assumiram a responsabilidade de expandir e gerenciar as equipes do Programa de Saúde da Família (PSF) e Programa de Agentes Comunitários de Saúde (PACS) em São Paulo (dentro do projeto QUALIS) foram: Fundação Zerbini na zona Norte e Sudeste e Casa de Saúde Santa Marcelina na zona Leste. Depois outras OS, que já estavam gerenciando hospitais, também entraram no "ramo" da AB como: Sociedade Paulista para o Desenvolvimento da Medicina (SPDM), que "ocupou" as zonas Leste e Sudeste; a Universidade Santo Amaro (UNISA) "ocupando" uma parte da zona Sul e a Congregação Santa Catarina também na zona Sul da capital paulista. (Capistrano Filho, 1999; Seixas, 2003).

Atualmente, seis em cada dez unidades de saúde não são administradas diretamente pela prefeitura da cidade. A prefeitura privatiza a saúde no município através de mecanismos legais tais como: contratos de gestão (firmados com as OS) e convênios (nos quais a prefeitura terceiriza a prestação de serviços de saúde). Dos 941 equipamentos de saúde do município de São Paulo, 602 são terceirizados, sendo todas as Assistências Médicas Ambulatoriais (AMA), $\mathbf{3 5 1}$ das $\mathbf{4 4 1}$ Unidades Básicas de Saúde (UBS), 14 dos 15 Prontos-Socorros (PS) e Pronto-Atendimentos (PA), 53 dos 78 Centros de Atenção Psicossocial (CAPS) e todos os 50 serviços de diagnósticos por imagem. As OS são responsáveis por $75 \%$ das consultas médicas da rede municipal de saúde (Bedinelli, 2012).

São contabilizados 26 contratos entre OS e prefeitura e há evidências de falhas na fiscalização desses contratos, segundo o Tribunal de Contas do Município (TCM) como metas não cumpridas e dinheiro colocado em aplicações financeiras, o que não é 
permitido, pois, nos contratos e na lei, tais organizações não possuem fins lucrativos (Bedinelli, 2012).

Por ser uma entidade privada marcadamente organizada pela lógica do mercado (hegemônica e ideologicamente colocada como superior à lógica estatal, considerada retrógrada) essas OS promovem alterações significativas na organização dos processos de trabalho nas unidades de saúde gerenciadas por essas instituições. Os processos de trabalho são pautados na lógica da gestão por metas na qual a produtividade é medida pela quantidade de atendimentos realizados e os trabalhadores não possuem planos de carreira, nem espaços de reflexão e formação política. Sofrem com o assédio moral da empresa e a ameaça contínua da demissão. A cobrança é cada vez mais acirrada e o trabalhador não encontra espaço na unidade para repensar as formas de se produzir saúde onde as práticas acontecem (Calipo, Soares, 2008; Santos, 2007).

É o caso dos enfermeiros, por exemplo. Estudo de Santos (2007) mostra que estes trabalhadores se ressentem de executar tarefas que the são impostas por programas definidos em nível central, sem possibilidade de construção de alternativas, caso o trabalhador identifique outras necessidades da população do território. Isso engessa as práticas destes trabalhadores, o processo de trabalho dentro das unidades e, em última instância, o processo de produção de serviços de saúde.

$\mathrm{Na}$ área de drogas a situação é ainda mais complexa, pois a lógica privada, que direciona a organização dos processos de trabalho nas UBS, e o modelo de atenção hegemônico, pautado na doença e na demanda espontânea e sustentado pelo tripé médicoequipamento-medicamento, não reconhece a questão da Saúde Mental, de forma geral, e o consumo de drogas, especificamente, como problemas complexos e que exigem ações inter e intrasetoriais. Também não reconhecem a necessidade de incluir efetivamente a $A B$ na rede de atenção e cuidado aos portadores de 
distúrbios mentais, incluindo os usuários de drogas (Soares, 2007; Sousa, Hamann, 2009; Silveira, Vieira, 2009; Munari et al, 2010).

A história do cuidado com o usuário de drogas prestado na dimensão da $A B$ ainda é marcada por questões atinentes ao campo da constituição fragmentada das políticas públicas brasileiras na área da saúde e, em particular, das políticas e das práticas de enfrentamento do fenômeno do consumo de drogas na contemporaneidade. Esta história foi pautada em paradigmas que desconsideram a $A B$ e não consideram este nível da atenção como espaço potente para a construção de uma assistência digna e de qualidade também para a população que faz uso prejudicial de drogas como veremos a seguir.

\subsection{HISTÓRIA DAS POLÍTICAS NA ÁREA DE DROGAS: REFLEXOS NA AB}

Para compreendermos como a $A B$ se manteve alheia ao processo de configuração da rede de atenção às pessoas que fazem uso prejudicial de drogas precisamos analisar como essa rede de atenção foi sendo forjada ao longo da história, a partir das políticas públicas de saúde direcionadas ao público que consome substâncias psicoativas (Machado, Miranda, 2007; Alves, 2009).

É de conhecimento público e bastante lembrado também nos estudos acadêmicos que o consumo de drogas está inscrito na história da humanidade. Entretanto, nas civilizações antigas, esse consumo era controlado por normas culturais e sociais compartilhadas coletivamente (Carneiro, 2002; Alves, 2009; Carneiro, 2010). Na era moderna, com o advento do capitalismo, a evolução tecnológica, o isolamento dos princípios ativos das principais substâncias psicoativas derivadas de plantas e o surgimento de drogas sintéticas cada vez mais potentes, torna a regulação do consumo de drogas uma questão a ser equacionada 
pelo Estado, através da formulação e implementação das políticas públicas (Alves, 2009).

As políticas públicas são consideradas mecanismos, que reproduzem as disputas de interesses que ocorrem nos bastidores das formulações destas políticas dentro do Estado (principal arena de disputas de interesse na contemporaneidade) e refletirão, sobretudo, os interesses da classe dominante (política e econômica) da época (Viana, 2006).

No Brasil, as primeiras referências de políticas públicas em relação ao consumo de drogas datam do início do século $X X$ e tinham caráter proibicionista, em conformidade com movimentos internacionais, que postulavam um mundo livre de drogas, e que, neste período histórico, estavam em franca expansão pelo mundo (Carneiro, 2002; Rodrigues, 2003; Santos, 2008; Alves, 2009). Já nas primeiras décadas do século XX essa "guerra" foi se conformando como perseguição a algumas substâncias derivadas de plantas (ópio, maconha e coca) e posteriormente a países periféricos, considerados produtores e exportadores das matériasprimas destas drogas como a China, a Índia, os países africanos e latino-americanos (Rodrigues, 2003).

Datam desta época as primeiras conferências internacionais organizadas para construir consenso internacional entre os Estados em relação ao status das substâncias psicoativas. Derivam desses consensos as classificações das substâncias psicoativas conforme a legalidade ou ilegalidade das mesmas, assim como os diferentes graus de periculosidade para a saúde dos consumidores. É importante ressaltar o caráter político de tais consensos e convenções e o papel fundamental das Organizações das Nações Unidas (ONU), criada em 1945, na legitimação destes consensos e reprodução do paradigma proibicionista na política global antidrogas (Carneiro, 2002; Rodrigues, 2003; Machado, Miranda, 2007; Alves, 2009; Passos, Souza, 2011). 
O Brasil é signatário de todos estes consensos internacionais, o que explica a hegemonia do paradigma proibicionista nas políticas públicas de drogas brasileiras, que se mantém até a atualidade. Essas políticas, de um modo geral, refletem a visão dominante que define e direciona as respostas sociais à problemática do consumo de drogas na contemporaneidade, enfatizando a relação produto/indivíduo e expressando o moralismo implícito na construção deste binômio (Brites, 1999; Karam, 2005; Machado, Miranda, 2007).

As primeiras intervenções do governo brasileiro para responder ao consumo de drogas datam do início do século $\mathrm{XX}$, com a construção de um aparato jurídico de criminalização de condutas referentes ao consumo de drogas ilícitas e exclusão dos usuários do convívio social através da prisão (Karam, 2005; Machado, Miranda, 2007; Alves, 2009).

A partir da década de 1970 o discurso biomédico/psiquiátrico passa a ser incorporado às políticas públicas sobre drogas no país (exemplo disso é a substituição do termo "viciado" para "dependente químico") e este discurso passa a influenciar a construção de estratégias de enfrentamento da questão das drogas no país, reforçando, contudo, as ações jurídicas e penais dominantes. Dessa forma, usuários de drogas começam a ser tratados de forma "diferenciada" pelo sistema penal, sendo considerados, em algumas situações, "doentes" e não apenas "marginais" (sendo que estas características estigmatizantes, muitas vezes se intercalam no discurso do senso comum e também nas políticas públicas). Decorrência dessa forma de conceituar o problema é a formulação da opção de internação de usuários de drogas em hospitais psiquiátricos, além da opção mais comum de encaminhá-los para a cadeia, conforme sua classe social. (Acselrad, 2005; Machado, Miranda, 2007).

O predomínio do discurso biomédico na área da saúde reforça a perspectiva da multicausalidade dos processos saúde-doença, 
quando não a da unicausalidade, proporciona um esvaziamento do conteúdo coletivo e político das intervenções em saúde, além de uma excessiva patologização e medicalização da vida. No campo das drogas, esse mesmo discurso reforça os aspectos farmacológicos das substâncias e criminaliza as consideradas ilícitas. Esse discurso enfatiza o "combate" a algumas drogas e culpabiliza o indivíduo que faz uso de determinadas substâncias, considerando esse consumidor como "doente", "frágil" ou "desviante", que precisa de ajuda para abandonar definitivamente (abstinência como única saída aceitável) seu hábito anormal (Bucher, 1996; Acselrad, 2005; Soares, 2007; Passos, Souza, 2011).

Com o início da redemocratização do país, na década de 1970 iniciou-se um movimento amplo de questionamento político e ideológico do status quo, inclusive na área da saúde pública, que se pautava na exclusão de parcela considerável da população que não tinha acesso aos serviços de atenção à saúde, por estarem fora do mercado de trabalho formal e/ou por não terem condições de comprar os cuidados no mercado privado de saúde, que era prevalente e estava em expansão no período da ditadura (Escorel et al, 2005). Sobre isso Escorel et al afirma:

Com a rearticulação paulatina dos movimentos sociais, tornaram-se mais frequentes as denúncias sobre a situação caótica da saúde pública e dos serviços previdenciários de atenção médica, e amplificaram-se as reivindicações de solução imediata para os problemas criados pelo modelo de saúde existente. Nesse contexto, sindicatos das diversas categorias profissionais da saúde - principalmente médicos, acadêmicos e cientistas debatiam em seminários e congressos as epidemias, as endemias e a degradação da qualidade de vida do povo. Um movimento pela transformação do setor saúde (...) fundiu-se com outros movimentos sociais, mais ou menos vigorosos, que tinham em comum a luta pelos direitos civis e sociais percebidos como dimensões imanentes à democracia (Escorel et al, 2005, p. 62).

É nesse momento histórico que estudiosos da área de drogas passam a ocupar espaços políticos importantes no governo e, com sua bagagem teórica e prática, estes sujeitos iniciam um processo 
de debate político sobre o tema. Segundo Machado e Miranda (2007):

\begin{abstract}
O processo de constituição da política de saúde para usuários de álcool e outras drogas deve ser considerado como um fato histórico, resultante de uma série de condições construídas em tempos e espaços diferentes, por meio de atores e práticas sociais diversos, imbuídos de diferentes significados e interesses (Machado, Miranda, 2007, p. 803).
\end{abstract}

A construção dos primeiros serviços públicos, especializados no atendimento aos usuários de álcool e outras drogas, têm início no começo da década de 1980 (o primeiro centro foi inaugurado em 1981), a partir da contribuição e participação desses sujeitos sociais. São serviços ligados às universidades públicas e com a finalidade principal de formação de trabalhadores para atuarem na área e produção de conhecimento (Machado, Miranda, 2007). Esse "atraso" é resultado das formas como a questão do consumo de drogas era encarada pelo poder público. Até essa época o consumo de substâncias ilícitas era incipiente no país, o de substâncias lícitas era tolerado e até ignorado e ambos ainda não eram considerados como problemas da esfera da saúde pública (Machado, Miranda, 2007; Alves, 2009).

Até a década de 1980 a "assistência" (na perspectiva da saúde e não apenas de uma resposta estatal ao problema, pois esta já era dada através do direito penal) às pessoas que consumiam drogas de forma abusiva e prejudicial, especialmente o álcool, era oferecido por serviços privados, filantrópicos e de cunho religioso, além dos manicômios e das prisões (Soares, Rohden, 1994). Esse tipo de "assistência", que interna e isola socialmente as pessoas que apresentam problemas com drogas, era considerado, e ainda é, por parcela significativa da população, a única possibilidade viável e eficaz de tratamento. É dessa época que vai se configurando a concepção hegemônica de internação como saída exclusiva para esse tipo de demanda. 
Em estudo desenvolvido por Soares e Rohden (1994) observa-se que até 1980 a atenção aos usuários de drogas era oferecida quase que exclusivamente por instituições religiosas, hospitais e clínicas psiquiátricas (80\%). Este estudo revela que a partir dessa década o tema de álcool e outras drogas ganha relevância e novas instituições começam a disputar espaço na seara do combate e tratamento do consumo de drogas. Mas continuam reproduzindo o paradigma proibicionista, associado de forma harmônica com o modelo da abstinência.

Outro estudo mais recente da Secretaria Nacional sobre Drogas (SENAD) aponta que $67,7 \%$ das entidades que oferecem algum tipo de tratamento para as pessoas que consomem drogas são de caráter não governamental e apenas $31 \%$ são serviços prestados por órgãos governamentais. Dos serviços governamentais apenas $7 \%$ são CAPS ad. Os demais são hospitais (geral e psiquiátrico), comunidades terapêuticas e hospital-dia. O tipo de tratamento oferecido por esses serviços tem caráter individual e restrito à perspectiva biomédica. Nas instituições governamentais o que prevalece é a psicoterapia individual e nas instituições não governamentais as internações são prevalentes (Brasil, 2007).

Comparando os dois estudos, nota-se que, apesar da introdução da Redução de Danos (RD), como um novo paradigma para a atenção aos usuários de drogas, a partir da década de 1990, e de sua adoção pelo Ministério da Saúde como marco teóricopolítico para a atenção aos usuários de álcool e outras drogas, nos anos 2000 continua prevalecendo a internação como proposta dominante na atenção à saúde dos usuários de drogas.

A política brasileira para questões relacionadas ao consumo de drogas é, atualmente, de competência do Ministério da Justiça (MJ), através da SENAD, antes denominada Secretaria Nacional Antidrogas (Brasil, 2005). Este órgão coordena e integra as ações do governo em relação à prevenção do uso indevido de drogas, bem como ao tratamento, a recuperação e a reinserção social dos 
usuários de drogas e lançou em 2005 a Política Nacional sobre Drogas (Fonseca, Bastos, 2005; Alves, 2009). Esta política, segundo Alves (2009):

[...] se orienta para redução da oferta (ações de prevenção e repressão ao tráfico de drogas ilícitas), a redução da demanda de drogas (prevenção, tratamento, recuperação e reinserção social) e a Redução de Danos (Alves, 2009, p. 2316).

Como referido anteriormente, no Brasil é recente o movimento de reflexão sobre o fenômeno do consumo de drogas na esfera da saúde e a construção de uma política sobre drogas fora do âmbito da justiça criminal (Marques, Doneda, 1998). Esse tema, como uma preocupação das autoridades de saúde do Brasil, emergiu definitivamente com a epidemia de AIDS a partir da década de 80. O HIV disseminava-se rapidamente principalmente entre usuários de drogas injetáveis e seus contatos (parcerias sexuais ou de uso). Em função disso, desenvolveram-se no país diversas experiências pragmáticas para o enfrentamento deste problema (Canoletti, Soares, 2005; Fonseca, Bastos, 2005). Antes da AIDS a questão das drogas era tratada quase que exclusivamente na esfera jurídica e religiosa (Karam, 2003; Fonseca, Bastos, 2005; Passos, Souza, 2011).

O MS, por intermédio da Coordenação de Saúde Mental, elaborou em 2003 a Política do MS para Atenção Integral a Usuários de Álcool e outras Drogas. Essa política, diferentemente da Política Nacional sobre Drogas da SENAD, adota uma abordagem que amplia a forma de conceituar o fenômeno do consumo de drogas, considerando-o uma questão de saúde pública conectado aos aspectos sociais como pobreza, desigualdade social e de acesso aos direitos sociais. Nessa política o usuário deixa de ser um criminoso e passa a ser um real beneficiário de políticas sociais e de saúde (Fonseca, Bastos, 2005). A RD é encampada nessa política como marco teórico e estratégia organizadora da rede de atenção 
aos usuários de drogas. No texto que expõe a política, a RD é apresentada da seguinte forma:

Se afirmamos que a redução de danos é uma estratégia, é porque entendemos que, enquanto tal, e para ter a eficácia que pretende, ela deve ser operada em interações, promovendo o aumento de superfície de contato, criando pontos de referência, viabilizando o acesso e o acolhimento, adscrevendo a clientela e qualificando a demanda, multiplicando as possibilidades de enfrentamento ao problema da dependência no uso do álcool e outras drogas. Neste ponto, a abordagem se afirma como clínico-política, pois, para que não reste apenas como "mudança comportamental", a redução de danos deve se dar como ação no território, intervindo na construção de redes de suporte social, com clara pretensão de criar outros movimentos possíveis na cidade, visando avançar em graus de autonomia dos usuários e seus familiares, de modo a lidar com a hetero e a autoviolência muitas vezes decorrentes do uso abusivo do álcool e outras drogas, usando recursos que não sejam repressivos, mas comprometidos com a defesa da vida. Neste sentido, o locus de ação pode ser tanto os diferentes locais por onde circulam os usuários de álcool e outras drogas, como equipamentos de saúde flexíveis, abertos, articulados com outros pontos da rede de saúde, mas também das de educação, de trabalho, de promoção social etc., equipamentos em que a promoção, a prevenção, o tratamento e reabilitação sejam contínuos e se dêem de forma associada (Brasil, 2004, p. 10).

Há no Brasil um embate político e ideológico no campo das políticas de enfrentamento da questão das drogas (haja vista termos duas políticas destoantes em vigor no país atualmente). Há aqueles que defendam uma postura firme e rígida do Estado na redução da oferta das substâncias, a partir de uma política repressiva e criminalizadora, e outro grupo que luta por um debate mais esclarecedor sobre o consumo de drogas na contemporaneidade e que coloca na arena de discussão questões sociais (como a desigualdade social) e de saúde, fundamentais para uma compreensão mais abrangente do assunto. Aqui se congregam os que consideram a opção pelo consumo de drogas um direito de foro particular e os que consideram a natureza social do consumo prejudicial de psicoativos. O embate é salutar para o 
desenvolvimento democrático de propostas, políticas e ações de enfrentamento do fenômeno das drogas no país.

Porém, o que limita o alcance das políticas públicas mais abrangentes como a do MS é a própria postura do Estado e da sociedade que assumem apenas a posição proibicionista e hegemônica no momento de enfrentar as questões relacionadas ao consumo de drogas.

Assim, dada a atual correlação de forças, prevalecem no plano das políticas públicas efetivas ações voltadas para a criminalização e no melhor dos casos tratamento do problema como dependência/doença, com o Estado reconhecendo e sustentando as prisões e os centros privados de tratamento. Exemplo bastante atual do predomínio de ações nessa direção é o Programa "Crack, é possível vencer" da SENAD em parceria com alguns ministérios, que investirá quatro bilhões de reais até 2014 em ações relacionadas ao "combate" ao consumo de crack, com características retrógradas, como ações repressivas nos locais de uso, investimento em Comunidades Terapêuticas (CT) e Centros Especializados de Tratamento para internação de usuários (Brasil, 2012).

Esse posicionamento contraditório dentro do Estado é mais um dos entraves para o desenvolvimento de propostas adequadas para o enfrentamento das questões referentes ao consumo de drogas, seja nos espaços de formulação das políticas públicas, seja nos espaços institucionais de assistência à saúde como as UBS (Fonseca, Bastos, 2005).

Enquanto a SENAD apoia e investe recursos em serviços que continuam reproduzindo unicamente o discurso médico/psiquiátrico no tratamento aos usuários de drogas, o MS defende a construção de uma rede de atenção aos usuários de álcool e outras drogas pautada em equipamentos extra-hospitalares, comunitários e em parceria com a $A B$.

As diretrizes da Política do MS para a Atenção Integral a Usuários de Álcool e outras Drogas estão em consonância com os 
princípios da política de saúde mental vigente, regulamentada e respaldada pela Lei Federal 10.216 - Lei da Reforma Psiquiátrica, sancionada em 06 de abril de 2000 - ambas consideradas progressistas (Brasil, 2004).

Para normatizar e regulamentar a rede de atenção aos usuários de álcool e outras drogas, o MS publicou algumas portarias voltadas para a estruturação de rede de atenção específica a estas pessoas (MS, 2004):

- Portaria $\mathrm{GM} / 336$ de 19 de fevereiro de 2002 que define normas e diretrizes para a organização de serviços que prestam assistência em saúde mental, tipo Centros de Atenção Psicossocial - CAPS, incluídos aqui os CAPS voltados para $\mathrm{O}$ atendimento aos usuários de álcool e outras drogas, os CAPS ad;

- Portaria SAS/189 de 20 de março de 2002 que cria, no âmbito do SUS, os CAPS ad que são serviços de atenção psicossocial para o desenvolvimento de atividades em saúde mental para pacientes com transtornos decorrentes do uso prejudicial e/ou dependência de álcool e outras drogas e que abrigam em seus projetos terapêuticos práticas de cuidados que contemplam a flexibilidade e a abrangência possíveis e necessárias a esta atenção específica, adotando a perspectiva estratégica de redução de danos sociais e à saúde.

A necessidade de definição de estratégias específicas de enfrentamento que visam ao fortalecimento da rede de assistência aos usuários de álcool e outras drogas, com ênfase na reabilitação e reinserção social dos mesmos, levou o MS a instituir o Programa Nacional de Atenção Comunitária Integrada aos Usuários de Álcool e outras Drogas mediante a consideração da multiplicidade de níveis de organização das redes assistenciais localizadas nos Estados e Distrito Federal, da diversidade das características populacionais existentes no país e da variação da incidência de transtornos 
causados pelo uso abusivo e/ou dependência de álcool e outras drogas (MS, 2004).

A política do MS propõe a revisão dos modelos assistenciais vigentes no país para conseguir contemplar as necessidades da população que faz uso de drogas. Para isso propõe a construção de uma rede de atenção comunitária, que engloba dispositivos extrahospitalares (que atuam a partir de perspectiva transversalizadora) e ressalta a busca ativa e sistemática das demandas dessa população estigmatizada, escondida e que se encontra marginalizada e excluída do sistema de saúde (Brites, 1999, Silva, 2008).

Para a implementação dessa rede torna-se necessário que a $A B$ seja incluída e participe ativamente, uma vez que o MS reconhece a abrangência limitada dos CAPS ad e a necessidade de capilaridade dessa rede, através dos serviços de $A B$, para a criação de formas variadas de acesso e de qualificação das demandas (MS, 2004).

Apesar da política do MS reconhecer a importância e a centralidade da $A B$ na construção de uma rede de atenção aos usuários de drogas, a realidade é bem diferente, pois, historicamente, a UBS e os trabalhadores aí inseridos não tomaram como objeto do processo de trabalho o cuidado aos usuários de drogas e, por conta disso, estes trabalhadores permanecem na periferia do debate sobre drogas, descolados e alienados da realidade do consumo de drogas no território onde atuam (Soares et al., 2011). A reestruturação da $A B$ reforçou esse afastamento da $A B$ da questão das drogas, pois este tema ficou de fora do "pacote mínimo" de programas e demandas a serem contemplados por estes serviços (Soares, 2007 e 2011). 


\subsection{COMO A AB TRANSITA NA ESFERA DO CUIDADO À POPULAÇÃO USUÁRIA DE DROGAS}

A realidade concreta dos serviços de saúde na $A B$ atesta o fato de que a questão do consumo de drogas está presente no cotidiano dos trabalhadores de saúde que atuam nestes espaços. Porém, estes trabalhadores encontram-se inertes, frente a essa problemática, por conta da falta de estímulo para criação de espaços abertos de discussão e reflexão sobre o fenômeno aqui explorado. Esse "acobertamento" do tema das drogas gera medo, insegurança em lidar com questões relativas ao consumo de drogas, aumento do preconceito e da intolerância e, finalmente, uma grande dificuldade de produzir práticas de saúde equânimes e dignas para uma parcela da população que opta por fazer uso de alguma substância psicoativa e que necessita de algum cuidado em relação a este uso (Rossi et al, 2007; Gonçalves, Tavares, 2007; Dimenstein et al, 2009).

A revisão bibliográfica realizada sinalizou que, assim como diversas áreas da $\mathrm{AB}$, também a Saúde Mental e a atenção à saúde de usuários de drogas não estão contempladas neste "pacote mínimo" e quando há alguma ação voltada para estes públicos especificamente, ela é focalizada, fragmentada e desenvolvida graças ao interesse de um ou outro trabalhador que se identifica com esta demanda, em especial o profissional da área de enfermagem (Gonçalves, 2002; Gonçalves, Tavares, 2007; Barros, Pillon, 2007; Delfini et al, 2009, Vecchia, Martins, 2009; Munari et al, 2010;).

A revisão bibliográfica realizada acerca do tema da $A B$ e assistência ao usuário de álcool e outras drogas foi pouco frutífera, apresentando um conjunto ínfimo de trabalhos. Dos estudos analisados, poucos apresentavam uma análise crítica sobre os processos de produção dos serviços de saúde na $A B$ e as formas de organização dos processos de trabalho neste âmbito de atenção dirigidos para as questões do consumo de drogas. Também não se 
encontrou estudos que apresentam uma análise propositiva sobre as possibilidades e potencialidades de ação e transformação da realidade, a partir das práticas, por parte dos profissionais de saúde da $A B$, em relação ao consumo de drogas e nem a $R D$ como promotora de cidadania e alternativa viável de cuidado à população usuária de drogas neste nível da atenção (Spricigo, Alencastre, 2004; Spricigo et al, 2004; Gonçalves, Tavares, 2007; Barros, Pillon, 2007).

Cabe salientar que a atuação do enfermeiro na $A B$, frente ao problema do uso de drogas, é objeto da maior parcela dos estudos encontrados, podendo-se supor que as dificuldades, contradições e os embates encontrados no cotidiano de trabalho dos enfermeiros da $A B$, bem como as práticas inovadoras e potentes realizadas por estes profissionais, são compartilhadas por outros profissionais de saúde que atuam na atenção primária.

Esses estudos sugerem a existência de condições mais favoráveis para a atuação do enfermeiro nessa área do que para os demais profissionais (principalmente os de nível superior), em função da proximidade/vinculação que os enfermeiros desenvolvem com os sujeitos ao exercer o cuidado/prestação de serviço (Spricigo, Alencastre, 2004; Spricigo et al, 2004; Barros, Pillon, 2007; Gonçalves, Tavares, 2007).

Uma discussão também pertinente, que permeia a totalidade dos trabalhos analisados, no tocante à assistência à população que faz uso de substâncias psicoativas, diz respeito à formação dos trabalhadores que atuam na $A B$. Segundo esses estudos, a formação desses trabalhadores na temática do consumo de drogas é limitada e superficial, incapaz de contribuir para que os profissionais rompam com o modelo clínico e biomédico (Gonçalves, 2002; Campos, Soares, 2004; Spricigo, Alencastre, 2004; Spricigo et al, 2004; Gonçalves, Tavares, 2007; Barros, Pillon, 2007; MorettiPires et al, 2011). 
Historicamente na formação dos trabalhadores de saúde, as questões sobre consumo de drogas são tratadas na disciplina de psiquiatria, com carga horária reduzida e enfoque no tratamento de doenças como as psicoses e neuroses. Recentemente foi introduzida a disciplina de Saúde Mental aos currículos de graduação de algumas profissões da saúde. Porém, o que se nota é que não houve mudanças significativas no tocante ao conteúdo ensinado, que continua pautado no modelo biomédico (Campos, Soares, 2004; Moretti-Pires et al, 2011).

A formação dos trabalhadores da saúde sequer acompanha as políticas públicas já estabelecidas e a produção de conhecimento científico na área de drogas. As práticas tornam-se, dessa forma, esvaziadas de sentido, ineficazes e inoperantes. Segundo Spricigo et al (2004):

\begin{abstract}
A perspectiva de que o tema drogas passe a fazer parte das preocupações da enfermagem, requer que a capacitação de seus profissionais agregue conhecimentos para além do paradigma clínico biomédico, da visão de distúrbio somático (psicológico ou transgressão social) e inclua saberes dos campos das ciências sociais, antropologia, política, dentre outros, além do domínio de métodos de pesquisa que possibilitem uma aproximação ao tema (drogas) nos seus vários aspectos (Spricigo et al, 2004, p. 298).
\end{abstract}

Os trabalhadores de saúde da $A B$ e também os gestores são confrontados com o desafio de romper:

1) Com o modelo biomédico de atenção à saúde que é ultrapassado, mas hegemônico na área da saúde;

2) Com a lógica da saúde como mercadoria, fortemente incorporada pelo Estado, pelas instituições e pela sociedade;

3) Com uma política pública sobre drogas fortemente ideológica, que segue as diretrizes propostas pelo paradigma de "guerra ás drogas".

Sem esses "rompimentos" fica muito difícil estabelecer propostas (políticas e práticas) que abordem integralmente um 
fenômeno tão complexo quanto o consumo de drogas (Andrade, 1998; Gonçalves, 2002; Bastos, 2003; Soares, 2007; Passos, Souza, 2011). Para que isso aconteça é necessário que os trabalhadores da $A B$ sejam formados seguindo novos paradigmas que possibilitem analisar a realidade e as questões sociais diretamente relacionadas ao processo saúde-doença de forma ampliada (Queiroz, Salum, 1996; Schraiber, Mendes-Gonçalves, 1996; Spricigo et al 2004).

É importante ressaltar que os textos analisados corroboram com a política do $M S$, reforçando a importância estratégica da $A B$ e da ESF especificamente como um lócus importante de ação para o enfrentamento das questões referentes ao consumo de drogas (Gonçalves, 2002; Spricigo, Alencastre, 2004; Spricigo et al, 2004; Gonçalves, Tavares, 2007; Barros, Pillon, 2007; Passos, Souza, 2011). Entretanto, na prática, a $A B$ não é considerada como espaço potente no enfrentamento das questões relacionadas ao consumo de droga e este fato pode ser justificado pela ausência dos trabalhadores e gestores da $A B$ na construção das políticas públicas direcionadas às questões concernentes ao consumo prejudicial de drogas.

As práticas direcionadas ao consumidor de drogas nesses espaços são escassas e caracterizam-se por serem pontuais, incipientes, focalizadas, muito limitadas, e pautadas no paradigma dominante de "guerra às drogas" (Gonçalves, 2002; Spricigo, Alencastre, 2004; Spricigo et al, 2004; Barros, Pillon, 2007; Gonçalves, Tavares, 2007).

Pode-se apontar, a partir da análise das publicações levantadas na revisão bibliográfica (análise esta que seguiu os fundamentos da saúde coletiva) algumas razões que levam o profissional da $A B$ a se "distanciar" de questões referentes ao consumo de drogas no cotidiano do seu trabalho:

- Processos de trabalho que não permitem reflexão sobre as práticas e sobre o cotidiano do serviço; 
- Formação insuficiente e limitada sobre a questão do consumo de drogas na contemporaneidade;

- Questões morais e de juízos de valor se sobressaindo em relação à ética no atendimento das questões relacionadas ao consumo de drogas;

- Gestão na área de saúde direcionada pela lógica custobenefício em detrimento da lógica das necessidades de saúde dos diferentes grupos sociais.

A partir dessas observações e para compreender como a rede de atenção às pessoas que fazem uso de álcool e outras drogas está sendo construída no município de São Paulo e qual(is) o(s) papel(is) que assume (m) a $A B$ na configuração desta rede é que se propôs este estudo.

As perguntas que possibilitaram o recorte do objeto de estudo deste trabalho são:

1) Como as questões sobre o consumo de drogas chegam até as UBS?

2) Como os profissionais de saúde lidam com tais questões no cotidiano do seu trabalho?

3) E, por último, como monitoram os desdobramentos desse atendimento na vida das pessoas que chegam até a unidade trazendo problemas relacionados ao consumo de drogas lícitas ou ilícitas? 
Considerasões teóricas 



\section{CONSIDERAÇÕES TEÓRICAS}

O objeto desta pesquisa será analisado com base na vertente epistemológica do materialismo histórico dialético. O paradigma marxista (também conhecido por paradigma crítico ou históricocrítico) reconhece que o conhecimento é produzido a partir da realidade, mas esta realidade é socialmente determinada pelo curso dos eventos históricos, das ideologias que dominam uma dada época ou momento histórico específico, do modo de produção e de reprodução social e das correlações de forças entre os diferentes grupos sociais (Triviños, 1987; Salum, Queiroz, Soares, 1999; Soares, 2007).

O paradigma crítico é contestador da ordem vigente, pois ao revelar a essência da realidade aparente (ideologia), a partir da análise crítica das contradições existentes nessa realidade, acaba produzindo conhecimento que denuncia a estrutura e dinâmica da formação social que em última instância encontra-se na base dessas contradições (Triviños, 1987; Salum, Queiroz, Soares, 1999; Soares, 2007).

Compreender o fenômeno do consumo de drogas através do paradigma crítico é localizá-lo dentro da estrutura da sociedade, organizada a partir da sua base econômica (modo de produção capitalista), base social (classes sociais) e geo-espacial (território onde acontece a dinâmica social, ou seja, o espaço concreto onde acontece a produção - formas de trabalhar - e a reprodução social formas de viver/consumir - de um determinado grupo/classe social). Essa consciência ampliada dos fenômenos permite compreender os diferentes desfechos que o consumo de drogas produz, nos diferentes grupos sociais, cujas formas de trabalhar e de viver são diferentes, conforme sua inserção no momento de produção (Queiroz, Salum, 1996; Soares, 2007). 
Esse paradigma crítico influencia o campo da Saúde Coletiva. Esta reconhece o processo saúde-doença intimamente relacionado às formas de trabalhar e de viver de determinada coletividade sendo um fenômeno social e não apenas uma associação de causas e efeitos que levam ao adoecimento ou à vida saudável (Salum, Queiroz, Soares, 1999; Soares, 2007).

\subsection{O FENÔMENO DO CONSUMO DE DROGAS NA CONTEMPORANEIDADE}

Em todas as sociedades, de todos os tempos, há relatos do consumo de variadas substâncias com o poder de alterar a consciência, podendo ser considerada uma prática milenar, fazendo parte de muitas culturas e das sociedades humanas ao longo de sua história (Carneiro, 2002). Entretanto, na sociedade capitalista atual a droga tornou-se mais um bem de consumo, uma mercadoria, capaz de saciar o desejo (real ou construído) do homem e que traz em seu bojo toda a ideologia mercadológica neoliberal (Soares, 2007).

Carneiro $(2002,2010)$, importante historiador brasileiro, que estuda o fenômeno do consumo de drogas desde épocas remotas até a atualidade, nos remete ao consumo de certas substâncias que alteram os estados de consciência em todas as sociedades humanas, mas particularmente no século $X X$ esse consumo passa por alterações significativas. Segundo $o$ autor:

A primeira questão a se definir é a de que as drogas são necessidades humanas. Seu uso milenar em quase todas as culturas humanas corresponde a necessidades médicas, religiosas e gregárias. Não apenas o álcool, como quase todas as drogas são parte indispensável dos ritos da sociabilidade, da cura, da devoção, do consolo e do prazer. Por isso as drogas foram divinizadas em inúmeras sociedades. As formas de usos, entretanto, são regulamentadas de formas diferenciadas, e no século $X X$, encontramos o estatuto de uma proibição formal de certas substâncias e a aceitação de outras. A discriminação das substâncias obedece a injunções culturais e econômicas. Embora o álcool tenha sido vítima da primeira lei seca norte-americana, ele em geral é tolerado nas sociedades ocidentais, assim como o tabaco, enquanto substâncias reconhecidamente mais inócuas, como os derivados da canábis, mantém-se sob 
interdição. O julgamento da legitimidade ou não destas necessidades é arbitrariamente estabelecido. O uso de uma justificativa médica e de saúde pública para se proibir certas drogas é contraditório com o fato de que algumas das substâncias mais perigosas são permitidas devido ao seu uso ser tradicional no Ocidente cristão. O cigarro, por exemplo, desde a guerra da Criméia incorporou-se à ração dos exércitos e aos hábitos populares, o chá e o ópio à dieta da Inglaterra vitoriana e o álcool, na forma do vinho, da cerveja e dos destilados continua sendo a bebida nacional de muitas nações (Carneiro, 2002, p.117).

O consumo de drogas na atualidade é um fenômeno influenciado pelos modos desajustados e injustos da sociedade se organizar e estes modos estão intimamente relacionados às contradições que 0 capitalismo promove e aos valores contemporâneos, social e historicamente definidos a partir das formas de produção e de reprodução social (Soares, 2007). Chama a atenção o papel que a droga executa no (dis)funcionamento social na atualidade como bode expiatório e/ou inimigo a ser destruído (Bucher, 1996). Segundo Passos e Souza (2011) o papel de bode expiatório se associa ao papel mercadológico:

O modelo repressivo da política estatal contra as drogas evidencia um modo de operar no qual o Estado se vê às voltas com os efeitos da própria globalização da economia e do avanço da lógica neoliberal, ampliando o poder repressivo do Estado-Mínimo e o poder de governo do mercado transnacional sobre os próprios Estados Nacionais. Estabelece-se uma aliança entre termos aparentemente contraditórios, mas que comungam de interesses comuns, de modo a preservar a lógica de mercado. É neste cenário macropolítico que as drogas tornaram-se um mal a ser eliminado pelo Estado e, ao mesmo tempo, um produto a ser altamente consumido pela classe média e alta (Passos, Souza, 2011, p. 156).

Tal fenômeno, quando analisado pelo paradigma dominante do proibicionismo, apresenta uma compreensão restrita e bastante limitada, enfocando apenas o poder da substância em si e/ou seus efeitos sobre o organismo e/ou o usuário, o que, por seu turno, evidencia a fraqueza dos indivíduos na sua relação com as drogas. O binômio indivíduo-droga parece existir no vácuo.

Segundo Brites (1999): 
Como toda compreensão moralizante pautada na absolutização de valores e no preconceito moral, esta visão que enfatiza o binômio produto/indivíduo é destituída de historicidade e assume uma função ideológica de legitimação do processo de dominação. Com relação ao produto, por exemplo, ao atribuir uma potencialidade "viciante" ao produto-em-si, oculta-se tanto a diversidade de usos existentes da mesma droga, quanto aos contornos diferenciados dos usos em contextos particulares (Brites, 1999, p.15).

Nos discursos correntes sobre drogas não há a assimilação e legitimação do discurso em que a droga é encarada como mercadoria, agregando valor de uso e de troca para estas substâncias. Ao contrário, o discurso legitimado pela maioria demoniza algumas substâncias, que são associadas diretamente com a perdição e com o mal. Esta demonização está na gênese da ideologia proibicionista e tal ideologia proporciona uma análise simplista, alarmista e catastrófica do consumo de drogas (Bucher, Oliveira, 1994; Bucher, 1996).

Este discurso proibicionista é tomado de forma acrítica pelos trabalhadores da área de saúde e gestores públicos, definindo as concepções destes em relação ao fenômeno do consumo de drogas na contemporaneidade e impregnando também as políticas públicas direcionadas à população que faz uso de drogas (Alves, 2009).

O enfoque utilizado na construção das principais intervenções do Estado em relação ao consumo de drogas $^{2}$ parte sempre da mesma matriz, que defende a cruzada belicista contra algumas drogas e/ou contra alguns tipos de usuários de drogas (especialmente os usuários de drogas pobres, excluídos pela sociedade e considerados perigosos) que são associados ao que há de pior na sociedade e culpados pelas mazelas sociais, acobertando

\footnotetext{
2 Vide exemplo das ações promovidas pelo poder executivo federal em parceria com a SENAD e com diferentes ministérios como o Plano Integrado de Enfrentamento ao Crack e Outras Drogas. Este plano visa a distribuição de recursos federais para estados e municípios desenvolverem ações de prevenção ao uso, tratamento e reinserção social de usuários de crack. Essas verbas deverão ser destinadas para ações que aumentem e estruturem a rede de atendimento aos usuários de drogas. Além disso, há prerrogativa de investimento em ações de caráter repressivo (como aparelhamento das polícias e instalação de câmeras de segurança nos locais de uso) e investimento em Comunidades Terapêuticas (Brasil, 2012).
} 
assim as contradições produzidas pelo modo de produção capitalista. Desse modo, exclui-se da análise o contexto socioeconômico e cultural dos diferentes usos de droga.

Essa cruzada contra algumas substâncias psicoativas, especialmente aquelas consideradas ilícitas, assume o nome de "guerra às drogas" desde o pronunciamento do então presidente dos EUA Richard Nixon que, em 1972, identifica os psicoativos ilícitos como o inimigo número 1 da América (Rodrigues, 2003). Desde sempre foi esse país o grande articulador desta guerra mundial contra algumas substâncias psicoativas (Rodrigues, 2003; Karam, 2003, 2005; Machado, Miranda, 2007; Santos, 2008).

Há uma efervescência do tema a partir do século XX, quando o fenômeno global do consumo de drogas passa a ser influenciado diretamente por interesses econômicos e políticos de alguns países imperialistas, que utilizam a questão do "problema das drogas" como uma nova estratégia de dominação e sujeição de países de capitalismo periférico, como os países latino-americanos (Rodrigues, 2003; Passos, Souza, 2011). Neste momento histórico assiste-se a um endurecimento das sociedades modernas em relação a algumas substâncias psicoativas.

Segundo Santos (2008),

De maneira geral, o século passado representou período de grande intolerância social em relação a um certo conjunto de drogas psicoativas e de fortalecimento de políticas proibicionistas, criminalizadoras e repressivas (Santos, 2008, p.17).

Com o proibicionismo ignoram-se as questões sociais que estão relacionadas ao aumento exponencial do consumo de drogas na contemporaneidade e os danos à saúde da população, causados pelo uso abusivo e/ou problemático de drogas, são muitas vezes considerados de forma enviesada e/ou relegados (Santos, 2008).

O fenômeno do consumo de drogas é considerado na esfera da saúde pública apenas na sua relação com os distúrbios mentais que podem ser ocasionados a partir do uso nocivo de drogas, como 
a dependência, ou pelos efeitos farmacológicos da substância no organismo (Santos, 2008). Essa forma hegemônica de apreender o fenômeno pelo setor saúde guarda íntima relação com a grande influência do discurso médico/psiquiátrico que, a partir da década de 1970, passa a ocupar também os espaços políticos que debatem o consumo de drogas pela sociedade e produzem as políticas públicas e as intervenções estatais visando o controle social e não o cuidado e a assistência aos usuários problemáticos de drogas (Machado, Miranda, 2007).

Além disso, o desenvolvimento científico e tecnológico, a partir do século $X X$, possibilitou uma nova relação dos homens com as substâncias psicoativas extrapolando os aspectos culturais do consumo, assumindo diferentes conotações que reforçam aspectos compulsivos, consumistas e hedonistas do uso de drogas e encaixam-se perfeitamente aos valores da contemporaneidade. (Carneiro, 2002; Machado, Miranda, 2007; Soares, 2007).

Porém, com a maior notoriedade que o tema foi ganhando nas últimas décadas, fez-se necessário agregar a perspectiva de outras áreas do conhecimento (principalmente das ciências sociais) para conseguir compreender o fenômeno em sua magnitude e complexidade e, dessa forma, formular propostas que respondam de maneira menos parcelar e fragmentada aos desafios que a questão do uso de substâncias psicoativas coloca para as diversas áreas do conhecimento, em especial a área da saúde (Soares, 2007).

Apesar do aumento, a partir da década de 1970, no número de estudos que abordam de maneira mais abrangente o fenômeno do consumo de drogas na sociedade, na área da saúde ainda predomina a visão biomédica/psiquiátrica do consumo de drogas. Neste referencial enfocam-se apenas os prejuízos biológicos deste consumo ou, no máximo, seus riscos para a psique humana. (Santos, 2008; Alves, 2009).

O setor saúde só passou a reconhecer o consumo de drogas como um problema da saúde pública a partir da década de 1980, 
principalmente por conta da epidemia de AIDS que trouxe a tona os danos á saúde causados pelo uso nocivo de drogas, como a proliferação de doenças infecto-contagiosas a partir do uso injetável de substâncias psicoativas. Antes disso, a questão do consumo de drogas era assumida quase que exclusivamente pela esfera jurídica e penal (Delgado, 2005; Machado, Miranda, 2007).

Com o lançamento da Política do Ministério da Saúde para Atenção Integral a Usuários de Álcool e Outras Drogas no ano de 2003, o MS reconhece a necessidade de superar o atraso histórico de assunção da responsabilidade de atendimento aos usuários de drogas pelo SUS. Esta política é considerada progressista, por trazer em seu bojo, influências teóricas de outros campos do conhecimento como da Saúde Coletiva, da Redução de Danos ampliada e da Promoção da Saúde. Ela também amplia o objeto das práticas ao escapar da ótica predominantemente psiquiátrica das intervenções do setor saúde na área de drogas no país (Brasil, 2004).

A "Promoção da Saúde" trouxe para o roll de conceitos que direcionam as políticas públicas (incluindo as políticas de saúde voltadas para as questões referentes à saúde mental e a política do MS para atenção ao usuário de álcool e outras drogas) algumas "novidades" como os conceitos de "risco", "empoderamento", "estilos de vida saudáveis" (Stotz, Araújo, 2004, Soares, 2007). Mesmo com a inclusão destes conceitos no direcionamento das políticas e das práticas voltadas para os usuários de drogas, estas não mudaram o caráter conservador e de controle social das políticas públicas, especialmente as políticas na área de drogas (Stotz, Araújo, 2004; Soares, 2007; Santos, 2008).

A Saúde Coletiva, quando incorporada na construção das políticas públicas na área da saúde, contribui positivamente ao retomar temas essenciais para uma compreensão ampla do processo saúde-doença, que são marginalizados e/ou excluídos do debate no momento de construção de tais políticas. Temas como a desigualdade social, os conflitos e contradições entre as diferentes 
classes sociais, a determinação social do processo saúde-doença e a dominação dos interesses privados (capitalistas) em detrimento dos interesses coletivos são intencionalmente colocados à margem nas políticas públicas de forma geral ou tratados de maneira superficial, servindo apenas como pano de fundo para tais políticas. Exclui-se (intencionalmente também) a reflexão sobre as consequências desastrosas das reformas neoliberais, que trazem em seu bojo os eventos adversos da globalização e do desemprego (Silva, 2008; Soares, 2007).

Esse movimento de retirar os aspectos sociais dos debates acerca das políticas de saúde, que acontece também ao se debater o fenômeno do consumo de drogas, acaba por limitar o olhar sobre o mesmo (Soares, 2007).

Soares (2007), a partir de uma análise contextual e histórica da Saúde Coletiva, mostra a importância de se compreender o processo contemporâneo de produção, distribuição e consumo da mercadoria droga - lícita ou ilícita - e sua relação com as formas atuais de acumulação capitalista. Segundo a autora:

[...] mostrar a pertinência de tomar o consumo contemporâneo de drogas como objeto da Saúde Coletiva significa percorrer o caminho de, em primeiro lugar, mostrar que esta é uma manifestação decorrente do modo como se organizou a produção e a distribuição da riqueza numa dada formação social.

Em segundo lugar, significa demonstrar a pertinência de colocar os valores sociais na posição de categoria mediadora para compreender os diferentes desfechos. [...] Significa demonstrar que os diferentes desfechos, também eles, serão mediados por valores estruturados e incorporados diversamente a depender das diferentes formas de reprodução social das famílias (Soares, 2007, p. 44).

Defende-se aqui que sem essa compreensão ampliada qualquer proposta política ou prática no campo das drogas será restrita e não permitirá um enfrentamento lúcido e sereno de um fenômeno que atinge de forma diferenciada as diferentes classes e grupos sociais. Por isso torna-se relevante levar em conta os contextos, valores e culturas para desenvolver estratégias de ação 
que sejam realmente eficazes e que atendam as necessidades da população que faz uso de drogas (Bucher, 1996; Silva, 2008; Soares, 2007).

A compreensão do fenômeno do consumo de drogas na contemporaneidade reflete o paradigma proibicionista hegemônico, que criminaliza e combate algumas substâncias contraditoriamente consideradas mais danosas e perigosas para a sociedade (Carneiro, 2002, 2010). A partir dessa compreensão bastante limitada é que são forjados os modelos de atenção aos usuários de drogas nas suas dimensões política, organizacional e tecnológica (Alves, 2009).

Estes modelos de atenção, embasados nessa concepção criminalizadora do fenômeno do consumo de drogas, não respondem adequadamente aos problemas relacionados ao consumo de drogas na sociedade, pois não ampliam o objeto do processo de trabalho e reproduzem o processo de produção dos serviços de saúde pautados numa lógica individualizante e estritamente biomédica do processo saúde-doença. Consequentemente, as práticas terão caráter individual, restrito aos sintomas clínicos dos sujeitos e não apreenderão as necessidades de saúde da coletividade. (Queiroz, Salum, 1996; Schraiber, Mendes-Gonçalves, 1996; Alves, 2009).

No processo de construção de um modelo de atenção capaz de fornecer uma atenção digna e verdadeiramente resolutiva para usuários de drogas, que esteja em consonância com os princípios do SUS e com a garantia dos direitos sociais (saúde, educação, moradia, cultura, lazer e segurança), é essencial que todos os sujeitos sociais implicados nessa construção, como trabalhadores da saúde, gestores e usuários de drogas, façam a reflexão sobre os paradigmas que influenciam as políticas públicas sobre drogas na contemporaneidade. Também é necessário conhecer os contextos em que as disputas entre paradigmas claramente opostos se colocam e quais são os verdadeiros interesses que estão por trás destas disputas e das decisões políticas que delimitam as 
intervenções do Estado diante do fenômeno do consumo de drogas. São nessas arenas de disputa que definem-se as formas como o Estado irá lidar (ou não) com os usuários de drogas.

Há dois paradigmas que, na atualidade, disputam entre si a influência nas decisões políticas do Estado em relação à questão das drogas no mundo: O paradigma proibicionista (guerra às drogas) e o paradigma da RD.

O paradigma proibicionista é hegemônico desde o seu surgimento, já no século XVIII nos EUA, até os dias de hoje (Carneiro, 2002, 2010). Já a RD é mais recente (as primeiras práticas datam do início do século XX na Inglaterra) e vem ocupando um espaço de destaque na polarização das disputas no campo das drogas (Santos, 2008).

As concepções do paradigma proibicionista (Guerra às Drogas) em relação ao fenômeno do consumo de drogas são pautadas principalmente nos efeitos da substância em si ou em aspectos relacionados ao indivíduo que consome tais substâncias.

A RD, por sua vez, apresenta diferentes definições, pautadas nas concepções que são tomadas para delinear o consumo de drogas na contemporaneidade. Para efeito deste estudo utilizaremos as concepções mais abrangentes de RD trazidas pelo campo da Saúde Coletiva, que apresenta a RD como uma nova construção, um novo paradigma ético, clínico e político para as políticas públicas na área de drogas que se coloca (em seus fundamentos, concepções e práticas) em oposição ao discurso hegemônico de "guerra às drogas" (Soares, 2007; Santos, 2008; Passos, Souza, 2011). Essa RD é denominada como RD ampla (Soares, Jacobi, 2000; Soares, 2007). A Saúde Coletiva entende que as formas pragmáticas de $\mathrm{RD}$, que consideram alguns aspectos do fenômeno apenas, limitam o alcance deste paradigma e pontua a necessidade de ampliação dos conceitos e das concepções que norteiam este paradigma para que, de fato, este exerça seu papel contra- 
hegemônico na construção de respostas adequadas ao fenômeno do consumo de drogas (Soares, 2007).

Os paradigmas do Proibicionismo e da RD ampliada são claramente opostos e na atualidade disputam espaço na determinação das políticas públicas de drogas no país e dos modelos de atenção que serão criados a partir dessas políticas. $O$ quadro abaixo aponta algumas diferenças fundamentais em relação aos dois paradigmas em disputa quando o assunto é o consumo de drogas na contemporaneidade (Soares, Jacobi, 2000).

Quadro 1 - Diferenças fundamentais entre o paradigma da RD ampliada e o paradigma de Guerra às Drogas.

\begin{tabular}{|c|c|c|}
\hline dagens & REDUÇÃO DE DANOS & GUERRA ÀS DROGAS \\
\hline & & \\
\hline CONCEPÇÃO & $\begin{array}{l}\text { A demanda e a oferta de } \\
\text { drogas constituem um um } \\
\text { processo histórico e social, que } \\
\text { remete a uma teia de } \\
\text { causalidade que envolve } \\
\text { indivíduos, famílias e grupos } \\
\text { sociais nas suas diferentes } \\
\text { possibilidades de reprodução } \\
\text { social. }\end{array}$ & $\begin{array}{l}\text { A droga é considerada a causa } \\
\text { dos problemas dos indivíduos, } \\
\text { desconsiderando-se o caráter } \\
\text { histórico e social do consumo } \\
\text { de drogas e os diferentes } \\
\text { significados que vem } \\
\text { adquirindo nader } \\
\text { contemporaneidade. }\end{array}$ \\
\hline PRESSUPOSTC & $\begin{array}{l}\text { A utilização de drogas é uma } \\
\text { realidader comprovada } \\
\text { historicamente em todas as } \\
\text { sociedades desde a } \\
\text { antiguidade. No capitalismo a } \\
\text { droga é uma mercadoria de } \\
\text { consumo que alimenta um dos } \\
\text { mais lucrativos comércios. }\end{array}$ & $\begin{array}{l}\text { Existe a possibilidade de uma } \\
\text { sociedade livre de drogas e } \\
\text { isso depende, sobretudo, do } \\
\text { esforço individual e da atitude } \\
\text { repressiva do Estado. }\end{array}$ \\
\hline IDEOLOGIA & $\begin{array}{l}\text { Realista, procura desfazer } \\
\text { mitos e preconceitos sobre } \\
\text { drogas e consumidores } \\
\text { através da formação de } \\
\text { sujeitos críticos. } \\
\text { Trabalha com informação } \\
\text { científica, com projetos de } \\
\text { fortalecimento dos indivíduos, } \\
\text { famílias e grupos sociais. }\end{array}$ & $\begin{array}{l}\text { Idealista, trabalha com } \\
\text { informação tendenciosa e } \\
\text { dirigida, criando mitos. Os } \\
\text { indivíduos são vistos como } \\
\text { indefesos, à mercê da droga, } \\
\text { ou "desviantes". Autoritarismo, } \\
\text { moralismo e preconceito são } \\
\text { difundidos através de } \\
\text { campanhas, comerciais de TV } \\
\text { e rádio, mensagens em } \\
\text { programas, filmes, séries e } \\
\text { telenovelas. } \\
\text { principalmente os meios de } \\
\text { comunicação de massa. } \\
\end{array}$ \\
\hline
\end{tabular}




\begin{tabular}{|c|c|c|}
\hline $\begin{array}{l}\text { MÉTODOS } \\
\text { ESTRATÉGIAS }\end{array}$ & $\begin{array}{l}\text { Adequados à realidade de } \\
\text { cada local, fortalecendo } \\
\text { indivíduos, famílias e grupos } \\
\text { sociais, não se limitando a } \\
\text { combater a droga ou o } \\
\text { pequeno tráfico. Não se } \\
\text { propõem a ser modelares, mas } \\
\text { adequados a cada situação. }\end{array}$ & $\begin{array}{l}\text { Punitivos, controladores, } \\
\text { partem de fórmulas } \\
\text { universalistas, aplicáveis em } \\
\text { qualquer situação que } \\
\text { abstraem os indivíduos de sua } \\
\text { singularidade e desconsideram } \\
\text { seus valores culturais ou suas } \\
\text { possibilidades concretas de } \\
\text { reprodução social. }\end{array}$ \\
\hline $\begin{array}{l}\text { OBJETIVO } \\
\text { FINALIDADE }\end{array}$ & $\begin{array}{l}\text { Abrange qualquer tipo de } \\
\text { avanço no sentido de } \\
\text { minimizar os prejuízos que } \\
\text { possam advir do consumo de } \\
\text { drogas lícitas ou ilícitas, e, } \\
\text { portanto, não visam somente a } \\
\text { abstinência como única meta } \\
\text { aceitável. }\end{array}$ & $\begin{array}{l}\text { Único: abstinência total de } \\
\text { qualquer consumo de drogas } \\
\text { ilícitas. }\end{array}$ \\
\hline
\end{tabular}

Fonte: Adaptação do texto de Soares e Jacobi (2000) e apresentado à disciplina sobre drogas e contemporaneidade.

Ao analisar o fenômeno do consumo de drogas na contemporaneidade pelo prisma da Saúde Coletiva torna-se evidente a complexidade de tal fenômeno e os prejuízos de limitar essa análise, pois isso implicará em políticas públicas e práticas estigmatizantes, condenatórias e contraproducentes (Santos, 2008). Quando todos os elementos envolvidos na questão do consumo de drogas são tomados em sua totalidade configura-se uma rica teia explicativa, que envolve usuários de drogas, trabalhadores da saúde, legisladores, gestores públicos e poder judiciário.

A RD ampliada se coloca como um paradigma contrahegemônico para o enfrentamento da questão das drogas pela sociedade, uma vez que, ainda hoje o paradigma proibicionista prevalece na construção de respostas ao consumo de drogas na contemporaneidade (Santos, 2008; Alves, 2009; Passos e Souza, 2011). Entretanto, sabe-se que para mudar paradigmas é preciso colocar em cheque o paradigma vigente, através de uma argumentação arrojada, teórica e cientificamente apoiada.

Em certa medida, investigações científicas vêm exercendo o papel de contestação do paradigma vigente, especialmente a partir de áreas do saber que promovem a discussão a partir de epistemologias críticas. Dessa forma, vem sendo constituído um 
novo paradigma interdisciplinar, que amplia a compreensão do fenômeno das drogas na contemporaneidade e, dessa forma, apoia a discussão social para a construção de políticas públicas abrangentes (Soares, 2007).

Entretanto, no cômputo geral, é modesta a fração de estudos que levam em conta essa nova proposta e este novo paradigma frente ao hegemônico. Os estudos analisados neste trabalho, com enfoque na atenção à saúde de usuários de drogas na $A B$, não apresentaram nenhuma referência ao movimento da RD (ampliada ou não), revelando desconhecimento ou desconsideração deste paradigma contra-hegemônico por parte dos pesquisadores e dos trabalhadores.

Neste espaço, defende-se que a ampliação do horizonte que esse paradigma pode trazer para as políticas e para as práticas em saúde são fundamentais para a estruturação de uma rede de assistência à saúde das pessoas que usam drogas, condizentes com os princípios do SUS. Compreender o fenômeno do consumo de substâncias psicoativas por um prisma mais abrangente deve pautar políticas públicas mais abrangentes na área. São estas políticas que direcionam as práticas assistenciais frente ao problema das drogas.

Chegar, porém, a essa compreensão ampliada constitui também um desafio, pois o fenômeno do consumo de drogas, além de ser complexo e envolver diversos fatores que o influenciam, é carregado de juízos de valor e preceitos morais (Baratta, 1994). Para se chegar a essa compreensão ampliada do fenômeno é necessário que novas concepções sejam construídas, a partir da reflexão crítica das concepções dominantes, e, a partir daí, incorporar estas novas concepções ao processo de produção dos serviços de saúde.

Isso requer desconstrução ampla dos mitos, valores e ideologias que sustentam o paradigma vigente e hegemônico de "guerra às drogas". Essa desconstrução deve ser iniciada nos bancos escolares, onde são formados os trabalhadores, que 
executam as políticas públicas através de suas práticas, os legisladores, que constroem o arcabouço jurídico e legal do país e os gestores que coordenam os trâmites políticos da execução das políticas públicas e o cumprimento das leis (Baratta, 1994, Bucher, 1996).

Os trabalhadores da saúde, especialmente os que estão na $A B$, subsidiam suas práticas direcionadas aos usuários de drogas no paradigma hegemônico proibicionista, pois também as políticas públicas nesse campo são pautadas neste mesmo paradigma, conforme nos aponta Alves (2009, p.2310) que parte do pressuposto teórico de que das políticas públicas na área de drogas emanam as racionalidades ou lógicas que orientam as práticas de atenção em saúde.

Nesse sentido, torna-se fundamental refundar tais práticas a partir da revisão crítica e reconstrução das políticas públicas na área de drogas. Entretanto, por conta das inúmeras contradições que os trabalhadores de saúde, de forma geral, e, em especial os da $A B$, encontram no cotidiano do trabalho, eles acabam se distanciando da problemática do consumo de drogas (Gonçalves, 2002). Algumas razões para este distanciamento podem ser compreendidas a partir da análise aprofundada de como se organizam os processos de trabalho nos microespaços das unidades de saúde, e, por conseguinte, compreender a lógica e a dinâmica do processo de produção dos serviços de saúde (Queiroz, Salum, 1996).

Torna-se pertinente, então, para compreender como estão configuradas as práticas dos trabalhadores de saúde da $A B$ em relação aos usuários de drogas, um aprofundamento nas questões relacionadas aos processos de trabalho e refletir sobre as estruturas nas quais se sustentam a produção dos serviços de saúde na $A B$. Um mergulho na realidade de trabalho destes sujeitos sem a compreensão teórica dos processos de trabalho em saúde e de como se dá a produção dos serviços de saúde no município hoje poderá levar a uma análise pobre e superficial do objeto de estudo. 


\subsection{TRANSFORMAÇÕES NO PROCESSO DE TRABALHO EM SAÚDE E O IMPACTO NO COTIDIANO DE TRABALHO DA AB}

\subsubsection{Crise, Neoliberalismo e Saúde}

A prestação de serviços de saúde pertence ao setor terciário da economia, ou seja, o setor de serviços, que nas últimas décadas foi o setor que mais cresceu e que mais emprega atualmente no Brasil. Este setor, assim como os outros setores da economia, tem passado por mudanças e reformulações ocasionadas principalmente pelo projeto neoliberal. Essa onda neoliberal trouxe para as relações de trabalho alterações profundas, que se concretizam no cotidiano dos trabalhadores e se expressam de diferentes formas nos corpos e nas subjetividades dos trabalhadores (Abramides, Cabral, 2003; Ribeiro et al, 2004; Antunes, 2006; Santos, 2007).

A classe trabalhadora brasileira, já nos primeiros anos do pósguerra, era uma classe madura e relativamente organizada, com alguns direitos e benefícios garantidos pelo Estado, apesar de não se poder afirmar que no Brasil, país de capitalismo periférico, consolidou-se um estado de bem-estar social (Viana,2009). Segundo Abramides e Cabral (2003) na América Latina o Welfare State não se concretizou, mesmo tendo um sistema de proteção social mínimo, pois as economias destes países periféricos estavam (e ainda estão) subordinadas ao capitalismo monopolista e aos países detentores do poder.

Com a crise do capitalismo na década de 1970, houve uma necessidade deste sistema produtivo se reinventar, uma vez que, neste momento histórico, além da crise mundial do petróleo e a queda vertiginosa na taxa de lucro das empresas, os trabalhadores de muitos países de capitalismo central apresentavam-se bastante organizados em sindicatos fortes e atuantes, que defendiam os interesses da classe trabalhadora. Este fortalecimento dos sindicatos e da classe trabalhadora promovia maior participação destes nas 
negociações coletivas com o patronato expondo claramente as contradições do capital. Nos países periféricos esse movimento dos trabalhadores ecoou de forma muito tímida (Boron, 1999; Abramides e Cabral, 2003).

A resposta do sistema capitalista mundial veio com um receituário político, econômico e ideológico para retomar e aumentar os padrões de acumulação. Esta estratégia foi denominada neoliberalismo e prega principalmente a soberania do mercado em detrimento da soberania dos estados nacionais e de todos os outros interesses. O Estado deve ser mínimo, dirigido estritamente por interesses capitalistas e não de defesa do cidadão. Com isso, o modelo produtivo sofre uma profunda modificação, evoluindo do modelo fordista-taylorista para o modelo toyotista. Entretanto, não houve uma substituição completa do modelo antigo pelo novo e sim uma sobreposição. Estes modelos coexistem numa manobra inteligente e perspicaz de aumentar a exploração dos trabalhadores, com formas mais sutis e não menos danosas de controle sobre a força de trabalho e sobre os processos de trabalho, para aumentar a acumulação (Boron, 1999; Abramides, Cabral, 2003; Antunes, 2006; Santos, 2007).

A reestruturação produtiva, desencadeada com 0 neoliberalismo, baseia-se no aumento da produtividade a qualquer custo, com aumento da eficiência, utilizando-se novas tecnologias e diferentes modelos de gestão da força de trabalho. Esta reestruturação não foca a melhoria da qualidade do e no trabalho e sim o aumento da acumulação capitalista em detrimento das condições de trabalho (Lacaz, 2000).

Através da precarização e desestruturação das relações de trabalho, gerenciamento mais rígido da força de trabalho, envolvimento diferenciado do trabalhador com a empresa ("eu sou a empresa") e uma ideologia que privilegia a competição, o individualismo e a culpabilização exclusiva do sujeito pelo seu sucesso ou fracasso, o neoliberalismo consegue redirecionar os 
rumos do capitalismo nas últimas décadas do século $X X$ e início do século XXI (Abramides, Cabral, 2003; Antunes, 2006; Santos, 2007). Segundo Abramides e Cabral (2003):

O mercado de trabalho passa por mudanças radicais em razão do processo de acumulação flexível, com flutuações constantes, aumento da competição, redução do poder aquisitivo do trabalhador e enfraquecimento do poder sindical, que começa a atuar na defensiva em razão da grande quantidade de mão de obra excedente (desempregados ou subempregados ou precarizados, vinculados à economia informal), o que dissocia ainda mais os interesses da classe trabalhadora (Abramides, Cabral, 2003, p.5).

Para os trabalhadores da área da saúde todas essas mudanças reverberaram de maneira peculiar, mas não menos prejudicial.

O ideário da Reforma Sanitária, que culminou na garantia da saúde como um direito social, expresso na Constituição Federal, foi duramente abalado com a ofensiva das políticas neoliberais no país já no governo Sarney, perpassando os governos de Collor e Itamar Franco e tendo sua expressão plena no governo de FHC (Noronha, Soares, 2001; Abramides, Cabral, 2003; Santos, 2007).

A saúde deixa de ser um direito e passa a ser uma mercadoria de grande rentabilidade. Segundo Santos et al (2007):

\footnotetext{
Num contexto de expansão e fortalecimento do capitalismo na perspectiva neoliberal, presenciou-se um retrocesso principalmente em relação à tarefa de proteção social conduzida pelo Estado, os direitos sociais foram lançados ao mercado e foram criados programas compensatórios para aqueles que não conseguem consumir bens nesse mercado (Santos et al, 2007, p. 778).
}

Essa mudança crucial na forma de encarar as questões relacionadas aos direitos sociais, e, especificamente, a área da saúde no país, contribuiu decisivamente para a forma como se reestruturou o sistema de saúde brasileiro a partir da Reforma Sanitária. Esta propunha um sistema de saúde público e de qualidade, que garantisse a todos os cidadãos acesso universal e 
igualitário aos serviços de saúde, sendo o setor privado complementar e não substitutivo. Mas as propostas de reorganização do sistema de saúde, defendidas pelo movimento da Reforma Sanitária, não conseguiram fazer frente à onda neoliberal que invadiu o país a partir da década de 1990.

A Reforma do Estado brasileiro, engendrada no governo de $\mathrm{FHC}$, consolidou hegemonicamente o neoliberalismo como política de Estado, sob a alegação de que esta seria o único caminho viável para que o país se constituísse numa nação competitiva e suficientemente forte para sobreviver às flutuações do "deus Mercado".

Essa Reforma do Estado prevê a existência de um núcleo estratégico onde são definidas as políticas e um setor de atividades essenciais que compreende as áreas de auditoria, fisco, segurança, arrecadação de impostos e tributos e de advocacia. Essas são áreas em que o Estado atua de forma exclusiva. Nas áreas sociais o Estado concorre com o mercado, associando o setor público e o privado para a execução das políticas e oferta de serviços. Isso repercute nas políticas de seguridade, saúde e previdência, educação e cultura. Um quarto setor compreende as atividades exclusivamente de mercado, com amplo programa de privatização (Abramides, Cabral, 2003).

Foi nesse contexto histórico que as reformas no sistema de saúde aconteceram, ora pendendo para o ideário da Reforma Sanitária ora pendendo para o lado do neoliberalismo, conforme as correlações de força e os jogos políticos e de poder (Heimann, Mendonça; 2005). Porém, o quadro que hoje se apresenta sobre a realidade dos trabalhadores em saúde se assemelha ao quadro geral da situação da classe trabalhadora no Brasil e no mundo. Segundo Costa e Tambellini (2009):

(...) as características do trabalho em saúde e as formas de inserção desses profissionais no mercado de trabalho apontam para a urbanização, especialização, redução da remuneração, multiplicidade de vínculos empregatícios, 
participação crescente de mulheres na categoria, elevado número de plantões entre as formas de trabalho e crescente informalidade nas relações de trabalho. Isso indica que o mercado de trabalho brasileiro no setor saúde vem reproduzindo a tendência geral da economia contemporânea de utilizar o expediente da flexibilização da contratação da força de trabalho (Costa, Tambellini, 2009, p. 962).

\subsubsection{Repercussões do Neoliberalismo para os trabalhadores de saúde da Atenção Básica}

Os trabalhadores da $A B$ também sofrem as repercussões da reestruturação produtiva, pois as formas como se organizam os processos de trabalho nessas instituições seguem, embora de forma mais sutil e por isso menos perceptível para os trabalhadores, os modelos gerenciais hegemônicos no mundo do trabalho e que se caracterizam como uma sobreposição entre os modelos tayloristafordista e toyotista (Peduzzi, 2002; Ribeiro et al, 2004). Esta lógica de se organizar os processos de trabalho na $A B$, reforçada a partir da instauração das parcerias público-privadas neste nível de atenção, foi discutida no trabalho de Santos (2007), que aponta aspectos relacionados ao fordismo-toyotismo na $A B$ tais como:

\footnotetext{
Organização e divisão do trabalho fundadas na produtividade, na cobrança repetida, na racionalização extrema - metas que não se colocam em discussão - de tal forma que o trabalho se realiza sob ameaça de um rolo compressor, limitando mesmo o cumprimento da rotina num clima de intensificação do trabalho, persistindo a velha divisão técnica entre trabalho manual e intelectual. $O$ trabalho em equipe aparece apenas como uma forma de racionalizar e agilizar as tarefas (...) [constituindo] um agrupamento de agentes marcados pela fragmentação e pela justaposição das ações (...) Explora-se a subjetividade do trabalhador, instaura-se a polivalência (...) e o alto grau de envolvimento com o trabalho caracterizado pela "entrega total" (Santos, 2007, p. 118 - grifos da autora).
}

Outro ponto que autores como Favoreto, Camargo Jr (2002), Ribeiro et al (2004), Scherer et al (2005) e Santos (2007) questionam refere-se à possibilidade da ESF, como principal ferramenta de operacionalização do SUS, romper com a hegemonia 
do atendimento individual, estritamente biomédico e consagrado no espaço dos serviços de saúde, a partir das formas atuais de se estruturar o processo de produção dos serviços de saúde na $A B$ e os processos de trabalho nesses equipamentos de saúde.

Já no início da implantação das primeiras equipes da ESF no país verificou-se um fenômeno que, posteriormente, se tornaria regra na implantação dessas equipes: a operacionalização desta estratégia através de parcerias público-privadas (Estado e OS). Pode-se considerar este fenômeno como um dos sinais do neoliberalismo e das Reformas do Estado na área da saúde. Se há 20 anos essas parcerias soariam como algo estranho, hoje elas são tão comuns que se naturalizaram, não sendo percebidas pela sociedade e pela maioria dos trabalhadores como formas diferenciadas e sutis de privatização da saúde pública no país. Seguindo a lógica privada de custo-benefício se instaura na área da saúde mecanismos de flexibilização do trabalho.

Alguns estudos (Baraldi, 2005; Nunes et al, 2006; Santos, 2007; Costa, Tambellini, 2009; David et al, 2009) sugerem que um sinal importante da precarização do trabalho em saúde manifesta-se na diversidade de formas de contrato e nos empregadores dos profissionais de saúde, que conformam-se como cooperativas, entidades governamentais e não governamentais. Nesse sentido, muitas vezes acabam coexistindo, no mesmo espaço de trabalho, profissionais com a mesma função, mas contratos de trabalho, salários e benefícios diferenciados. Isso gera uma das contradições presentes nos espaços de trabalho e afeta profundamente os trabalhadores e a sua relação com o trabalho em si.

Como reflexo da reestruturação produtiva no setor saúde ainda, o profissional de saúde da $A B$ vem assumindo novas formas de trabalhar. Agora é exigido dele que trabalhe em equipe (mesmo que a sua formação não contemple este tipo de atuação), com área adscrita de atendimento e co-responsabilização pela saúde de um número fixo de famílias de determinado território. Há metas de 
produtividade cada vez mais elevadas que são estabelecidas em nível central e fixadas segundo critérios quantitativos (Peduzzi, 2002; Ribeiro et al, 2004; Nunes et al, 2006; Santos, 2007). Há ainda entre estes profissionais um grande envolvimento pessoal com o trabalho desempenhado na equipe e uma idealização sobre este trabalho (ética, engajamento social e militância), que significam fatores de fortalecimento destes trabalhadores. Porém, os fatores de desgaste são proporcionalmente maiores e mais poderosos e levam a uma confusão sobre os significados do trabalho. Ora o trabalho é visto como libertador e construtivo, ora visto como fonte de sofrimento e dor e uma forma de aprisionamento (Salum e Queiroz, 2005; Santos, 2007; Trad, Rocha, 2011).

É possível perceber, nas formas de organização dos processos de trabalho na $A B$, características comuns da reestruturação produtiva a outros setores da economia como: polivalência dos profissionais, envolvimento maior com a empresa/instituição, maior intensidade nos ritmos de trabalho, maior conhecimento do trabalho, necessidade de maior criatividade para resolver os diferentes problemas que vão surgindo, uma falsa sensação de autonomia do trabalhador sobre seu trabalho e critérios de avaliação pautados na quantidade e não na qualidade do trabalho desenvolvido (Lacaz, 2000; Trad, Rocha, 2011).

Todos os fatores apontados anteriormente retroalimentam os processos de alienação do trabalhador, que raramente intencionaliza a transformação do objeto do processo de produção dos serviços de saúde, executando práxis reiterativas ${ }^{3}$. Os processos de trabalho em

\footnotetext{
${ }^{3} \mathrm{O}$ conceito de práxis é utilizado por Trapé, Soares (2007) em seu artigo. Elas utilizam as formulações de Vasquez (1977) sobre este conceito. Segundo as autoras: $A$ práxis se refere à ação do homem que transforma a natureza, fundamentada na teoria que existe para guiar a ação (...) Por outro lado, a forma como a consciência está presente na atividade prática do sujeito, configura diferentes níveis de práxis. Sendo assim, é possível distinguir a práxis criadora da práxis reiterativa. "A práxis se apresenta ou como práxis reiterativa, isto é, em conformidade com uma lei previamente traçada, e cuja execução se reproduz em múltiplos produtos que mostram características análogas, ou como práxis inovadora, criadora, cuja criação não se adapta plenamente a uma lei previamente traçada e culmina num produto novo e único (...) Historicamente, entretanto, esse
} 
Heloisa da Veiga Coelho

que os trabalhadores participam são engessados em instrumentos pré-definidos em níveis hierárquicos inacessíveis. Tais instrumentos muitas vezes não respondem às demandas da realidade concreta onde estes processos acontecem. Em suma, o trabalhador de saúde na $A B$ encontra-se na posição de instrumento do processo de trabalho, muito mais do que sujeito dele, afastado que está da possibilidade de compreender de maneira plena a complexidade do trabalho em si, que numa definição ampliada deveria ser:

Os atos realizados pelo conjunto de trabalhadores da saúde orientados por um projeto [o projeto de intervenção em Saúde Coletiva] que articula clínica e epidemiologia, sob a perspectiva do pensamento social em saúde, e que, na sua articulação, produzem a transformação no objeto (Queiroz, Salum, 1996, p.5).

Outro fator que deve ser ressaltado ao se atentar para o trabalho nas UBS é que os modelos assistenciais vigentes se organizam a partir de lógica que inverte todo o processo de trabalho (inserido numa "cadeia de produção") ao tomar como objeto a doença (manifestação individual do desgaste das formas de trabalhar e de viver dos grupos sociais) e não os perfis epidemiológicos (perfis de reprodução social e perfis de saúdedoença). A finalidade do trabalho passa a ser apenas tratar a doença e não visa à transformação dos perfis epidemiológicos. Os meios e instrumentos utilizados não promovem mudanças nesses perfis, mas corroboram com o círculo vicioso do consumo de serviços de saúde, que se resume a consultas individuais e exames, sem alterar em nada as formas de viver e de adoecer da população (Queiroz, Salum, 1996).

caráter criador do trabalho representado pelo trabalho artesanal foi sendo substituído pelo trabalho mecanizado, devido às exigências de aumento da produção da sociedade capitalista. Como consequência do próprio desenvolvimento técnico, sobreveio a crescente divisão e especialização do trabalho. "[Assim], os traços característicos da práxis criadora desaparecem do trabalho (...) [do homem]. A atividade parcelada, unilateral e monótona do operário foi fixada previamente, sem que ele tivesse nenhuma participação nisso. Ou seja, não só se fixa por antecipação, e de forma acabada, a finalidade de sua atividade, o objeto ideal que há de realizar, como igualmente todos e cada um dos passos que ele dará também são determinados de antemão, sem possibilidade de desvios (Trapé, Soares, 2007, p. 3). 
Esta nova forma de trabalhar na $A B$, que atinge principalmente trabalhadores de saúde da ESF, compromete a qualidade do trabalho e a saúde dos trabalhadores, devido aos seguintes fatores: sobrecarga de trabalho, impossibilidade de atender a todas as demandas/consultas que se apresentam no trabalho cotidiano dos serviços de saúde, cobrança exaustiva em relação às metas, compartimentalização e fragmentação do trabalho em equipe em função das metas, dos programas e dos protocolos pré-estabelecidos, ausência de autonomia e autogoverno por parte dos trabalhadores em relação ao seu trabalho, ausência de espaços coletivos de reflexão para os trabalhadores sobre questões relacionadas ao trabalho como condições de trabalho, qualidade de vida no trabalho e os processos de trabalho (Lacaz, 2000; Ribeiro et al, 2004; Santos, 2007; Trad, Rocha, 2011).

Estes trabalhadores, apesar de sua inserção privilegiada nos territórios onde trabalham e vivem as pessoas de diferentes grupos sociais, estão apartados da possibilidade de articular vida, saúde e doença desses grupos no momento de construírem suas intervenções, que são direcionadas apenas aos agravos na dimensão individual (Queiroz, Salum, 1996).

\subsubsection{Impactos do Neoliberalismo na produção de saúde na $A B$}

As modificações no mundo do trabalho, a partir da reestruturação produtiva, impactaram as formas de se produzir saúde nos diferentes espaços sociais onde as práticas em saúde acontecem. A assistência e o cuidado prestados pelos trabalhadores de saúde sofrem diretamente as influências negativas do neoliberalismo.

O processo de produção de serviços de saúde torna-se algo abstrato e os agentes dos processos de trabalho não protagonizam a implementação das políticas públicas de saúde, desconhecendo mesmo a sua responsabilidade pela concretização destas políticas. 
Falta-Ihes autonomia para definir e/ou construir os instrumentos do processo de trabalho mais adequados para a transformação do objeto do processo de trabalho, recortado a partir da realidade de saúde do território (Queiroz, Salum, 1996; Santos, 2007).

O processo de produção dos serviços de saúde na $A B$ não é definido a partir das necessidades de saúde da população de determinado território. Essas necessidades não suscitam tais serviços e nem embasam a sua estruturação. Tais processos são estabelecidos a partir de uma lógica mercantil (que determina todos os espaços de constituição da vida coletiva) colocando o usuário dos serviços de saúde como consumidor e não como um ser social. Como estratégia de racionalização dos gastos com saúde todo o sistema é pensado/organizado a partir de necessidades prédeterminadas oferecendo intervenções também pré-determinadas. Isso é concretizado através de programas de atenção à saúde de grupos específicos da população e estes grupos geralmente pertencem a classes sociais excluídas e em situação de pobreza e exclusão, perfazendo um grupo em situação de grande vulnerabilidade social (Schraiber, Mendes-Gonçalves, 1996; Soares, 2007; Calipo, Soares, 2008;). Segundo Nunes et al (2006):

\begin{abstract}
A realização do trabalho na saúde implica uma relação muito próxima entre os profissionais e os usuários, exigindo elevada capacidade de percepção, compreensão e compartilhamento das demandas que se apresentam como necessidades, nem sempre explicitadas. A partir destas demandas, constrói-se o objetivo ou a finalidade da ação profissional, a qual se reparte em muitas e diversificadas intervenções entre os trabalhadores dos serviços de saúde e seus respectivos instrumentos de trabalho. Uma visão dialética da necessidade em saúde obriga a reconhecer o caráter social tanto das necessidades quanto dos processos criados para atendê-las, e exige reafirmar que os carecimentos são criados e recriados na vida em sociedade, podendo, portanto, diferir em razão do grupo, do local e do tempo (Nunes et al, 2006, p. 511).
\end{abstract}

A estratégia atual de organização do processo de produção dos serviços de saúde na $A B$ e a forma de se estabelecer os diferentes processos de trabalho na ESF e também no modelo 
tradicional gera um engessamento da assistência à saúde prestada aos usuários destes serviços. Se a demanda de um usuário ou de um grupo extrapola os ditames dos programas do MS, como é o caso das demandas relacionadas ao consumo de drogas, este ficará sem solução ou resposta adequada. Quando muito alguns profissionais "mais envolvidos" e "engajados" com o bairro e com o serviço assume para si a tarefa de tentar dar alguma resposta à determinada demanda (Trad, Rocha, 2011).

Os trabalhadores dificilmente têm a oportunidade de localizar a origem destas demandas nas formas de trabalhar e de viver dos grupos sociais que trabalham e vivem nas áreas de abrangência da UBS e passam a percebê-las como uma propensão ou, no melhor dos casos, como uma vulnerabilidade de âmbito particular/individual. Isso gera um processo de naturalização das mesmas, impactando nas formas como estes trabalhadores irão lidar com tais demandas, tornando-os insensíveis ou cegos diante da complexidade que assumem as demandas dos usuários dos serviços de saúde da $A B$. Isto contribui para a alienação do trabalhador (Schraiber, MendesGonçalves, 1996; Soares, 2007).

É importante ressaltar que, em territórios que prevalecem a pobreza e a marginalidade social, as demandas que conseguem chegar até a unidade (diretamente pela incidência de uma doença crônica ou aguda ou escondida pelos véus de uma sintomatologia imprecisa) não podem ser respondidas ou resolvidas apenas pelo setor saúde (este é outro fator determinante nas condições de trabalho dos profissionais de saúde).

Para dar uma resposta adequada e eficiente aos problemas de saúde da população (que não se pode dissociar dos problemas sociais) torna-se necessário desenvolver ações intersetoriais, necessidade que vem sendo reiterada e exaustivamente discutida pela saúde coletiva. Porém, essas ações necessitam de uma grande articulação entre diferentes setores da sociedade, que devem se 
mobilizar pelo bem comum. Esse tipo de ação entra em contradição com o ideário neoliberal.

Supõe-se, portanto, que o setor saúde continuará sendo um dos únicos equipamentos sociais presentes (representando a presença do Estado no território) nos diferentes espaços sociais periféricos. Com dificuldades de articular-se aos poucos setores públicos presentes nesses espaços, como a escola (Soares et al, 2003) tentando dar conta de demandas, geradas principalmente pelas formas de reprodução social, que encontram-se na base dos modos de trabalhar e de viver dos grupos sociais que habitam 0 território.

O ciclo vicioso tende a continuar, pois os profissionais de saúde inseridos nessas realidades, tendem quase que como missão (Santos et al, 2007) a receber responsabilidades heroicas, e a continuar sofrendo, adoecendo e desenvolvendo mecanismos de proteção e defesa como a alienação, sem alterar substancialmente os processos de saúde-doença nem as formas de trabalhar e de viver da população do território da UBS.

Emana das concepções teóricas aqui tomadas para explicar a realidade de saúde e de assistência à saúde do usuário de drogas na $A B$, uma série de questões cujo ponto de partida diz justamente respeito ao projeto que propõe formas mercantis e privatistas de organizar os processos de produção dos serviços de saúde. Bem como o paradigma proibicionista, relativo ao fenômeno do consumo de drogas, este ganha hegemonia na atualidade, apesar das enormes lacunas e prejuízos sociais que fomentam.

Para explicar essa hegemonia, este trabalho acionou elementos estruturais e superestruturais da formação social vigente. Conforme o marxismo, que orienta este trabalho, tanto a questão relacionada aos processos de produção dos serviços de saúde como o fenômeno do consumo de drogas na contemporaneidade devem 
ser analisados a partir da totalidade social que corresponde à estrutura e à superestrutura da formação social capitalista ${ }^{4}$.

Nesse paradigma, a estrutura social é composta por sua base econômica (relações de produção e as forças produtivas), base social (classes e/ou grupo sociais) e base geo-social (territórios onde se dá a produção e o processamento da vida). Todos estes componentes estabelecem entre si uma relação dialética na dinâmica da sociedade para 0 atendimento das necessidades sociais (Queiroz, Salum, 1996; Soares, 2007). Nessa estrutura há de se levar em conta as relações entre os diferentes grupos sociais, que são relações de exploração entre classes sociais. Para que a classe exploradora mantenha o status quo é necessário um aparato jurídico, político e ideológico que legitime e/ou imponha o poder da classe dominante sobre as classes subalternas.

Conforme as definições desse paradigma ainda, a superestrutura é composta por todo esse aparato jurídico, político e ideológico construído para a manutenção do status quo e da classe dominante no poder. São mecanismos estabelecidos dentro e fora do Estado para este fim (Soares, 2007).

\footnotetext{
${ }^{4}$ Althusser, filósofo e estudioso das obras de Karl Marx refere que Marx concebe a estrutura de toda a sociedade como constituída por "níveis" ou "instâncias", articulados por uma determinação específica: a infra-estrutura ou base econômica (unidade das forças produtivas com as relações de produção) e a superestrutura que comporta em si mesma dois "níveis" ou "instâncias": o jurídico-político (o Direito e o Estado) e o Ideológico (as diferentes ideologias: religiosa, moral, jurídica, política, etc). Esta forma de estruturar a sociedade retoma as proposições do Materialismo Histórico e pode, segundo Althusser ser explicado através da metáfora do edifício que comporta uma base, que é a infra-estrutura, sobre a qual se erguem os patamares de superestrutura sendo que esta última não poderia se manter pairando no ar sem ter seus alicerces fundados numa base (Althusser, 1990).
} 

Gbjetiuns 



\section{OBJETIVOS}

\subsection{OBJETIVO GERAL}

Analisar as práticas voltadas para consumidores de drogas nos serviços de $A B$ em saúde, tomando por referência as políticas públicas de saúde brasileiras nessa área.

\subsection{OBJETIVOS ESPECÍFICOS}

- Levantar as práticas atuais voltadas para pessoas que fazem uso de drogas nos serviços de AB;

- Identificar como as demandas relacionadas ao consumo de drogas chegam aos serviços de $A B$;

- Apreender como os profissionais de saúde lidam com essas demandas no cotidiano do trabalho;

- Analisar a tendência dessas práticas frente às políticas públicas voltadas para usuários de drogas. 

OProcedimentos

Cetodológicos 



\section{PROCEDIMENTOS METODOLÓGICOS}

\subsection{TIPO DE PESQUISA}

Trata-se de uma pesquisa qualitativa, de natureza descritivoanalítica. A pesquisa assume o enfoque dialético-crítico, partindo da necessidade de conhecer a realidade social (aparência e essência do fenômeno) para transformá-la (Triviños, 1987). É intuito deste estudo não apenas descrever como são as práticas direcionadas aos usuários de drogas (natureza, tipo, variações), mas compreender como elas são forjadas a partir das políticas públicas que direcionam a produção dos serviços de saúde na $A B$, considerando o caráter histórico e provisório do conhecimento produzido a partir da análise de determinada realidade social (Minayo, 2004).

As práticas dos trabalhadores da $A B$ em relação aos usuários de drogas serão analisadas a partir dos discursos destes trabalhadores sobre o fenômeno do consumo de drogas na contemporaneidade, seu posicionamento diante de tal fenômeno e das necessidades e demandas que chegam aos serviços, moldadas pelo processo de produção de serviços de saúde e respondidas pelos processos de trabalho desenvolvidos na $A B$. A abordagem qualitativa permitirá enfocar a realidade a ser estudada a partir da experiência dos sujeitos que compartilham desta realidade (Minayo, 1994).

O método de análise da realidade seguiu os fundamentos do materialismo histórico e dialético, que permitiu observar a particularidade das práticas direcionadas aos usuários e drogas na $A B$ desenvolvidas pelos sujeitos da pesquisa na sua relação com a produção dos serviços de saúde para essa população no município de São Paulo e analisar os fatores condicionantes do modo de produção de serviços de saúde para a população usuária de drogas no município a partir das especificidades do fenômeno de produção 
das práticas dos trabalhadores da $A B$ voltadas aos usuários de drogas. Essa relação dialética entre o todo e suas partes direcionará a análise dos resultados do estudo em questão (Queiroz, Salum, 1996).

Por se tratar de um estudo que mergulha em contexto particular, torna-se possível um aprofundamento na realidade estudada, porém, os resultados indicam tendências e não podem ser generalizados para outras realidades. (Minayo, 1994).

\subsection{O CAMPO DE ESTUDO}

O campo de estudo escolhido para o desenvolvimento deste estudo é uma UBS do município de São Paulo.

A escolha desta unidade não se deu de forma aleatória. Foi escolhida a UBS Dr. Eduardo Romano Reschilian como campo deste estudo por ser uma unidade mista, com os dois modelos de $A B$ convivendo (o tradicional e a ESF) o que, em potência, ajudaria a problematizar possíveis diferenças no trabalho, e porque a pesquisadora já atuou como enfermeira da ESF neste serviço por aproximadamente quatro anos (no período de 2001 a 2004), o que permitiria uma fase exploratória de pesquisa bastante informada.

Dessa forma, apesar de ter ocorrido alterações significativas na unidade por conta de mudanças na gestão municipal e local, esta experiência de atuação na unidade proporcionou à pesquisadora conhecimento da área de abrangência da unidade, de seus equipamentos sociais e de saúde e da trajetória histórica do serviço. Isso facilitou o acesso ao campo de pesquisa, pois o conhecimento sobre a realidade de vida e de saúde dos grupos sociais que vivem naquele território e sobre os processos de trabalho em vigor na UBS permitiram que a pesquisadora construísse seu projeto de pesquisa, 
partindo de pressupostos concretos da realidade deste serviço de saúde.

A UBS faz parte da Coordenadoria Regional de Saúde da região Sudeste da Secretaria Municipal de Saúde (SMS) da Prefeitura Municipal de São Paulo (PMSP). Essa Coordenadoria Regional de Saúde é composta pelas subprefeituras de Aricanduva/Vila Formosa, Carrão, Ipiranga, Jabaquara, Mooca, Penha, Vila Mariana, Vila Prudente/Sapopemba. Na AB essa coordenadoria conta com 45 UBS, 196 ESF e 15 Núcleos de Apoio à Saúde da Família (NASF). Cada subprefeitura dessa coordenadoria tem uma Supervisão Técnica de Saúde. A UBS Reschilian faz parte da Supervisão Técnica de Saúde do Ipiranga e está localizada no Distrito Administrativo do Sacomã. Este distrito tem uma população de 247.851 pessoas vivendo nos 41 bairros do distrito, segundo dados do censo do IBGE de 2010, sendo que esta unidade está situada no Jardim Maristela (São Paulo, 2012).

O Jardim Maristela constituiu-se como bairro já na década de 1970. Pela proximidade com a região do $A B C$ (área de alta concentração de indústrias), o espaço se configurou como um bairro operário. $\mathrm{Na}$ atualidade é considerado um bairro tipicamente residencial, na região periférica do município de São Paulo, com alguns locais de concentração comercial (avenidas comerciais como as avenidas Padre Arlindo Vieira e Nossa Senhora das Mercês). Apresenta como características geo-espaciais, ruas residenciais e comerciais (prioritariamente com casas e pequenos prédios comerciais), favelas urbanizadas e não urbanizadas e conjuntos habitacionais populares. Quase a totalidade das ruas são asfaltadas (excluindo-se apenas as duas áreas de favela que são da área de abrangência da UBS).

A população pertencente à área de abrangência da unidade é de aproximadamente 32 mil habitantes, segundo o último censo realizado no ano de 2010, e se caracteriza por ser uma população com pouco acesso a bens materiais e imateriais. 
$\mathrm{Na}$ área de abrangência da unidade não há muitos recursos de lazer, cultura e trabalho. Há apenas escolas, creches e algumas poucas entidades filantrópicas e/ou religiosas com atividades direcionadas especialmente para crianças e jovens. Há muitas igrejas (especialmente as evangélicas) e bares, mas o espaço é destituído de áreas culturais e de lazer, acessíveis à população geral, como teatros, cinemas, clubes e parques na região. Há apenas o CEU Parque Bristol (Centro Educacional Unificado) e o SESI (Serviço Social da Indústria) que ficam na região, mas possuem acesso relativamente restrito.

A unidade de saúde conta com seis equipes de saúde da família, que cobrem aproximadamente $90 \%$ da população de abrangência da unidade. Além dos profissionais da ESF há profissionais de saúde que atendem seguindo as prerrogativas do modelo assistencial tradicional. Estes trabalhadores (dois pediatras, um ginecologista, dois clínicos gerais, um hebiatra e um psiquiatra) assistem aos usuários que se encontram fora da cobertura da ESF.

Alguns profissionais de saúde, por conta de sua especificidade (principalmente o psiquiatra e a hebiatra), atendem também aos usuários que moram nas áreas de cobertura da ESF. Além disso, a ausência de psiquiatra em outras UBS da região e a demanda crescente por esta especialidade acaba forçando uma espécie de referência desse profissional para toda a área.

A UBS conta ainda com uma equipe de NASF composta por dois terapeutas ocupacionais, dois psicólogos, dois fonoaudiólogos, um psiquiatra, um assistente social e um ginecologista. Estes trabalhadores são contratados em regime de 30 horas semanais e atendem essa e mais outras três UBS da Supervisão Técnica de Saúde do Ipiranga, contabilizando-se o total de 15 equipes da ESF. Essas têm cronograma de reuniões semanais com a equipe do NASF, conforme seus núcleos de assistência (saúde mental, reabilitação, saúde da mulher e criança). 
A circulação média de pessoas na unidade é de 500 pessoas/dia para consultas agendadas, procedimentos, acolhimento, grupos, agendamento de consultas e exames.

A Organização Social que administra a unidade, em parceria com a PMSP, desde 2001 é a SPDM. Essa OS tem um contrato de gestão com a PMSP para gerenciar a maioria dos equipamentos de saúde da Supervisão Técnica do Ipiranga. Ela assumiu a gestão desta UBS em 2001 com a implantação das primeiras equipes da ESF e é responsável pela contratação de todos os trabalhadores dessa estratégia, do NASF e da maioria dos auxiliares técnicos administrativos (ATA) que executam atividades burocráticas e atendimento na recepção da unidade. Além disso, desde o início de julho deste ano, a SPDM assumiu também a gerência da UBS, que até então era gerenciada por um trabalhador da prefeitura.

Com a entrada das OS na gestão dos serviços de saúde da PMSP tornou-se possível e naturalizado a convivência de diferentes formas de contratação (diferentes vínculos empregatícios, planos de carreira, cargos e salários) num mesmo equipamento de saúde, além da possibilidade de adesão de um trabalhador estatutário à ESF para complementação do salário, que é defasado na PMSP (Frente Nacional contra a Privatização da Saúde, 2011).

\subsection{SUJEITOS DE PESQUISA}

Os sujeitos de pesquisa são os trabalhadores de saúde que atuam na ESF, os trabalhadores que atuam na UBS e não estão inseridos na ESF (trabalhadores da PMSP) e trabalhadores do NASF. Todos estes sujeitos estão vinculados à UBS Dr. Eduardo Romano Reschilian e foram entrevistados conforme a distribuição a seguir:

- Seis trabalhadores da ESF;

- Três trabalhadores da PMSP; 
- Um trabalhador do NASF.

O critério de inclusão dos sujeitos da pesquisa foi ter atendimento prévio de demandas relacionadas às questões do consumo de drogas.

A seleção dos trabalhadores da ESF que seriam entrevistados acontecia sempre ao término de uma reunião de apresentação do projeto de pesquisa.

Os trabalhadores da prefeitura foram convidados a participar do estudo conforme sua afinidade e especificidade com a temática do consumo de drogas e não aleatoriamente. A hebiatra foi escolhida por conta da sua trajetória histórica na unidade e também por ser a única trabalhadora que desenvolve atividades específicas para a população jovem do bairro. O psiquiatra e a assistente social da prefeitura foram eleitos como sujeitos do estudo por estarem diretamente relacionados ao atendimento das demandas relacionadas ao consumo de álcool e outras drogas na UBS.

\subsection{COLETA DE DADOS}

\subsubsection{Fase exploratória}

Nessa fase foram realizadas reuniões (previamente agendadas) com cada uma das equipes da ESF para apresentação do projeto de pesquisa, levantamento e discussão de casos (que eles tenham atendido e/ou discutido nas reuniões de equipe relacionados à questão do uso de drogas) e seleção de um membro de cada equipe para participar do estudo.

As reuniões sempre se iniciaram com a apresentação do projeto de pesquisa. Nessa apresentação a pesquisadora problematizava a questão do atendimento aos usuários de álcool e outras drogas na $A B$ a partir da sua experiência pessoal de atuação neste nível de atenção. Era solicitado então que os membros das 
equipes apresentassem, discutissem e analisassem alguns casos e demandas relacionadas ao consumo de drogas lícitas ou ilícitas que eles atenderam ou que acompanharam nos últimos meses.

Em algumas equipes foi possível desenvolver uma reflexão sobre alguns fatores imbricados no atendimento da população usuária de drogas na $A B$, mas essa reflexão não aconteceu de forma homogênea, pois em algumas equipes o tempo para a reunião e a disponibilidade dos trabalhadores em discutir o tema eram bem reduzidos. Essa indisponibilidade dos trabalhadores de algumas equipes tornou mais precária a discussão dos casos vivenciados e/ou discutidos pela equipe. Os Agentes Comunitários de Saúde (ACS) lembravam diversos casos de pessoas usuárias de drogas nas suas áreas de atuação, mas eram poucos os que estavam realmente vinculados à equipe.

Ao término dessas reuniões definia-se entre os membros da equipe aquele que seria entrevistado. Essas entrevistas com os trabalhadores da ESF eram então agendadas, conforme a disponibilidade do trabalhador.

Nessas reuniões foi possível identificar alguns trabalhadores que apresentavam maior afinidade e preocupação com a temática em relação a outros que, apesar de reconhecerem a existência destas demandas no território onde atuam, consideravam-nas irrelevantes diante das outras demandas do serviço.

Com os trabalhadores da prefeitura a abordagem foi direta (sem reuniões) e no momento do agendamento da entrevista a pesquisadora fazia a apresentação e contextualização da pesquisa.

Havia a proposta de realização de uma reunião com todos os trabalhadores do NASF para apresentação do projeto de pesquisa e seleção do trabalhador que seria entrevistado. Porém, desde o início da coleta de dados a pesquisadora tentou agendar essa reunião, sem sucesso. A reunião foi agendada por duas vezes pela coordenadora do NASF e desmarcada na última hora por conta de problemas com a agenda dos profissionais. Numa outra tentativa foi 
agendada uma reunião com uma das psicólogas da equipe. Esta exigiu o parecer do comitê de ética da PMSP e mesmo após a leitura do mesmo ela se sentiu insegura para realizar a entrevista. Ao final foi possível realizar apenas a entrevista com a assistente social da equipe.

\subsubsection{Fase de coleta de dados}

Os dados foram coletados a partir de entrevistas semiestruturadas, que, segundo Triviños (1987, p.146) "partem de alguns questionamentos básicos, apoiados em teorias e hipóteses que interessam à pesquisa, e que, em seguida oferecem amplo campo de interrogativas". Estas entrevistas foram realizadas utilizando-se um roteiro (Apêndice A) elaborado a partir do referencial teórico e pressupostos que embasaram o estudo, além do conhecimento prévio da pesquisadora acerca do objeto do estudo. Este roteiro serviu para orientar a conversa e obter um aprofundamento das questões relacionadas ao objeto.

O roteiro de entrevistas foi dividido em três partes:

1) Apresentação: Neste tópico foi solicitado que o entrevistado descrevesse sua trajetória profissional para identificação da relação que este trabalhador estabelece com a $A B$, além da descrição de sua formação na área de drogas com o intuito de identificar aspectos relevantes sobre essa formação que influenciam as práticas direcionadas aos usuários de drogas desenvolvidas por estes trabalhadores.

2) Demandas: Neste tópico foi solicitado que o entrevistado descrevesse como as demandas relacionadas ao consumo de drogas chegam ao serviço de $A B$ para identificar a relevância das mesmas na $A B$, bem como as formas que estas chegam e aspectos que podem interferir no acesso dessas demandas como preconceitos, 
estigmas e discriminação por parte dos trabalhadores e do próprio equipamento de saúde. Optou-se por questionar sobre as demandas relacionadas aos usuários de drogas, pois, diferentemente das necessidades de saúde, estas são melhor compreendidas pelos trabalhadores e tem relação com a procura de cuidados de saúde a partir de um carecimento (que é diferente de necessidade). Parte-se do pressuposto que não há, por parte do trabalhador da $A B$, um conhecimento sobre as necessidades de saúde dessa população específica e que estes sujeitos só são reconhecidos quando buscam ativamente por algum tipo de intervenção. Do contrário, o grupo de pessoas que consomem drogas não é contemplado em suas necessidades pelos serviços de saúde de maneira geral (Schraiber, Mendes-Gonçalves, 1996). Portanto, estabeleceu-se com os trabalhadores uma análise sobre as demandas relacionadas ao consumo de drogas que chegam à UBS.

3) Atendimento: Neste tópico foi desenvolvida análise junto aos trabalhadores sobre como estes atendem $e$ respondem em seu cotidiano de trabalho às demandas que chegam ao serviço e que são relacionadas ao consumo de drogas. Para tanto, buscou-se apreender qual objeto é tomado pelo trabalhador no processo de trabalho em que atua, quando a demanda chega por um usuário de drogas ou por seu familiar. Também foi intuito das questões deste tópico analisar a percepção dos trabalhadores sobre as práticas que estes executam e que são direcionadas aos usuários de drogas e seus familiares.

As entrevistas foram conduzidas pela própria pesquisadora e foram gravadas, mediante consentimento do entrevistado e assinatura do termo de consentimento livre e esclarecido (TCLE). 
Após a realização das entrevistas estas foram transcritas na íntegra para a realização da análise. Em todas as etapas da coleta de dados a pesquisadora participou ativamente, o que possibilitou uma ampla aproximação com os sujeitos da pesquisa e com os dados obtidos, iniciando o processo de análise já no momento da coleta e transcrição das entrevistas.

\subsection{PROCEDIMENTOS ÉTICOS}

O projeto foi encaminhado inicialmente para o Comitê de Ética em Pesquisa (CEP) da Escola de Enfermagem da USP (instituição sediadora da pesquisa) via Plataforma Brasil. Após o recebimento do parecer deste comitê, aprovando o estudo em questão (Anexo 1), o mesmo foi encaminhado para o CEP da PMSP para apreciação e análise, de acordo com as normas vigentes. Na PMSP, além de encaminhamento do estudo para o CEP, o projeto de pesquisa foi formalmente apresentado ao Núcleo de Educação Permanente da Coordenadoria Regional de Saúde da região Sudeste.

No CEP da PMSP o processo de apreciação levou mais de quatro meses, o que impactou negativamente no desenvolvimento da pesquisa. Essa lentidão pode ser atribuída: às exigências burocráticas que envolveram o registro do projeto no CEP; ao fluxograma precário de apresentação dos projetos; e à falta de clareza e objetividade das informações disponíveis sobre o processo (como: quem procurar nas coordenadorias e supervisões de saúde, como obter as assinaturas necessárias nestes espaços, como entrar em contato com os gerentes das unidades, o tempo de espera para o parecer e para a análise de pendências). Outro elemento que dificultou o processo diz respeito à leitura precária do próprio projeto apresentado, o que gerou a constituição de pendências desnecessárias.

Mesmo recebendo o parecer da PMSP (Anexo 2) aprovando a realização da pesquisa na unidade de saúde escolhida pela pesquisadora, ainda foi necessário aguardar algumas semanas para 
a liberação, pois, como a unidade estava passando por um momento de mudança de gestão (o gestor da prefeitura acabara de pedir exoneração do cargo e uma nova gestora, contratada pela OS, estava assumindo a gerência da unidade) foi exigido pela nova gestora uma apresentação formal da pesquisadora por parte dos interlocutores da $\mathrm{AB}$ da prefeitura e da OS.

Obedecendo aos preceitos da resolução 196/96, todos os participantes da pesquisa foram esclarecidos sobre: o teor do estudo, seus objetivos, autorização para gravação das entrevistas, divulgação dos dados apenas em publicações científicas, garantia do sigilo dos dados e do anonimato e possibilidade de desistência a qualquer momento do estudo sem prejuízo para os sujeitos.

Após esclarecimentos, todos os sujeitos assinaram o Termo de Consentimento Livre e Esclarecido (TCLE), elaborado em duas vias de acordo com as normas da resolução 196/96 (Apêndice B). Os participantes ficaram com uma cópia do TCLE possibilitando contato com a pesquisadora ou CEP para esclarecimentos de possíveis dúvidas ou desistência.

\subsection{ANÁLISE DOS DADOS}

A análise dos dados obtidos através das entrevistas seguiram as orientações de Bardin (1977) que trazem a análise temática como um conjunto de técnicas para o estudo das comunicações humanas, enfatizando o conteúdo destas comunicações. O objetivo da análise de conteúdo é compreender criticamente o sentido das comunicações, seu conteúdo manifesto ou latente, as significações explícitas ou ocultas (Chizzotti, 2010).

Além disso, utilizaram-se as indicações de outros pesquisadores do grupo de pesquisa, ao qual a pesquisadora é filiada, que usaram 0 método de análise temática para 0 desenvolvimento de seus estudos, procurando aproximação dialética com os dados e não apenas sua compreensão semântica. Nesse 
sentido, o grupo vem problematizando 0 método de análise escolhido, discutindo a aproximação analítica que requer que a análise leve em consideração o sujeito que traz o conteúdo à tona, o contexto em que esse conteúdo se apresenta e as categorias teóricas que ajudam a analisar aspectos estruturais da realidade encontrada (Santos, 2007; Santos, 2008; Silva, 2008).

Após a realização das entrevistas, estas foram transcritas e em seguida foi realizada uma primeira leitura pela pesquisadora (em conjunto com o áudio) para correção de possíveis incompreensões e confusões.

Para apresentação do método de análise utilizado fez-se necessário dividi-lo em três momentos específicos para tornar mais claro e compreensível o processo de desenvolvimento desta etapa do estudo.

\section{Momento 1 - Fichamento das entrevistas}

No primeiro momento da análise foi realizado o fichamento das entrevistas. Aqui os trechos que se referiam a alguns temas centrais dos discursos foram destacados no texto. Realizaram-se anotações, observações e direcionamentos nas margens das entrevistas, que caracterizavam os temas que iam surgindo ao longo da leitura das entrevistas.

Momento 2 - Fragmentação dos discursos e construção dos temas e subtemas

Neste momento os temas e subtemas foram classificados e ordenados num quadro. Este quadro foi construído a partir dos temas (numa leitura das entrevistas e das observações) e numa leitura seguinte das entrevistas, associando com o quadro dos temas, os subtemas apareceram e foram complementando o quadro inicial. 
$\mathrm{Na}$ leitura subsequente do material, estes subtemas foram classificados conforme seu tema. Esse processo de fragmentação gradual do material possibilitou, ao final deste processo, uma visão geral das categorias empíricas que compuseram o material das entrevistas.

A partir da decomposição do material elaboraram-se os seguintes temas centrais, que emanaram da análise temática das entrevistas dos trabalhadores:

- Processo de trabalho;

- Formação do trabalhador;

- Modelos e redes de atenção à saúde dos usuários de drogas;

- Demandas relacionadas ao consumo de drogas;

- Postura do trabalhador diante do fenômeno do consumo de drogas;

- Propostas de atuação dos trabalhadores diante do fenômeno do consumo de drogas;

- Distanciamento entre as políticas públicas e a realidade de implementação das mesmas.

Todos os subtemas foram classificados conforme os temas centrais e organizados num quadro geral analítico.

Momento 3 - Análise do conteúdo dos temas e subtemas e identificação da categoria de análise

O quadro geral de temas e subtemas - categorias empíricas conformam a categoria de análise processo de trabalho, capaz de expor o objeto do estudo e explicá-lo. É importante destacar que este trabalho de análise só é possível se estiver intimamente conectado com a bagagem teórica da pesquisadora. É esta teoria que direcionou o olhar da pesquisadora para determinados aspectos da realidade e dos dados obtidos. Este exercício de retomada constante do referencial teórico permitiu à pesquisadora um olhar 
mais apurado sobre os dados, relacionando os mesmos com a realidade concreta onde estão inseridos os sujeitos da pesquisa. 
Arálise dos

Resultados 



\section{ANÁLISE DOS RESULTADOS}

\subsection{QUEM SÃO OS SUJEITOS DE PESQUISA?}

Os sujeitos desta pesquisa são trabalhadores de saúde da $A B$, lotados na UBS Dr. Eduardo Romano Reschilian, que atuam na ESF ou no modelo de atenção à saúde tradicional, comumente denominado de "Modelo Tradicional".

Os trabalhadores que atuam no "Modelo Tradicional" possuem vínculo estatutário, o que thes confere segurança trabalhista. Dois são médicos, um é enfermeiro e um é assistente social. Encontram-se vinculados à unidade há muitos anos, o que certamente thes confere conhecimento da realidade de situação de vida e de saúde dos moradores do território e da realidade da produção de serviços de saúde no município, pois estes participaram das mudanças de governo e de gestão das políticas públicas de saúde em São Paulo, o que thes confere posicionamentos consistentes em relação à atenção à saúde no município.

Já os profissionais de saúde da ESF possuem vínculo trabalhista regido pela Consolidação das Leis do Trabalho (CLT) e são contratados pela OS responsável, integrando-se à $A B$ a partir de 2001. Por conta da recente implantação da ESF na UBS e da alta rotatividade desses trabalhadores, percebe-se posicionamentos menos contextualizados, perdidos em relação às referências históricas da realidade atual do processo de produção dos serviços de saúde na $A B$. Os sujeitos que participam de equipes da ESF são: dois enfermeiros e três ACS. A assistente social entrevistada vincula-se ao NASF, respondendo pelo trabalho de matriciamento em quatro UBS, num total de 15 equipes da ESF.

É importante destacar a convivência de diferentes vínculos e salários dentro de um mesmo equipamento de saúde, além da inexistência de um plano de cargos e carreiras em nenhuma das formas de contratação e da possibilidade organizacional e de 
gerência dos recursos humanos de trabalhadores com vínculo estatutário "aderirem" à ESF e complementarem seu salário (vínculo de 20 ou 30 horas com a PMSP e o restante da carga horária vinculada à ESF) como é o caso de E4.

O Quadro 2 apresenta algumas informações sobre os trabalhadores que foram entrevistados durante a coleta de dados:

Quadro 2 - Perfil dos trabalhadores entrevistados no estudo, São Paulo, 2012.

\begin{tabular}{|c|c|c|c|c|c|c|}
\hline $\begin{array}{c}\text { TRABA- } \\
\text { LHADOR }\end{array}$ & IDADE & SEXO & PROFISSÃO & $\begin{array}{c}\text { VÍNCULO } \\
\text { TRABALHISTA }\end{array}$ & $\begin{array}{c}\text { TEMPO NA } \\
\text { AB /UBS }\end{array}$ & $\begin{array}{c}\text { ESCOLARI- } \\
\text { DADE }\end{array}$ \\
\hline E1 & 58 & $\mathrm{~F}$ & Hebiatra & Estatutário & $30 / 25$ anos & Superior \\
\hline E2 & 26 & $\mathrm{~F}$ & ACS & CLT & $1 / 1$ ano & E. Médio \\
\hline E3 & 48 & $\mathrm{~F}$ & Assistente Social & Estatutário & $3 / 3$ anos & Superior \\
\hline E4 & 46 & $\mathrm{~F}$ & Enfermeira & Estatutário+CLT & $12 / 12$ anos & Superior \\
\hline E5 & 39 & $\mathrm{~F}$ & ACS & CLT & $11 / 11$ anos & Superior \\
\hline E6 & 53 & $\mathrm{~F}$ & ACS & CLT & $10 / 5$ anos & E. Fundamental \\
\hline E7 & 33 & F & Enfermeira & CLT & $6 / 6$ anos & Superior \\
\hline E8 & 29 & F & Enfermeira & CLT & $4 / 4$ anos & Superior \\
\hline E9 & 65 & M & Psiquiatra & Estatutário & $24 / 24$ anos & Superior \\
\hline E10 & 39 & F & Assistente Social & CLT & $3 / 3$ anos & Superior \\
\hline
\end{tabular}

\subsection{O QUE HÁ POR TRÁS DA AUSÊNCIA DE DEMANDAS RELACIONADAS AO CONSUMO DE DROGAS NA AB?}

Os trabalhadores de saúde da $A B$ assumem a tendência geral de evitarem as demandas relacionadas ao consumo de drogas, através de diferentes mecanismos intrínsecos aos processos de trabalho e, de maneira geral, ao processo de produção dos serviços de saúde na $A B$. Apesar da existência de tais mecanismos (nem sempre reconhecidos pelos sujeitos), que dificultam ou até mesmo impossibilitam o acesso das demandas relacionadas ao consumo de drogas, algumas delas conseguem chegar até a AB. Estas demandas provocam angústia e desconforto, pois os trabalhadores se consideram tecnicamente despreparados para produzir qualquer tipo de abordagem ao usuário e à sua família, que, na equação do 
consumo de drogas, são os únicos elementos eventualmente considerados pelo setor saúde. Neste caso, isso se deve mais por conta das concepções que explicam o consumo de drogas serem predominantemente biomédicas e menos por conta da clareza que o profissional de saúde possui sobre as limitações do setor e da necessidade de intersetorialidade.

A reiterada "falta" de formação técnica para lidarem com tal demanda e oferecerem algum tipo de resposta acaba constituindo a principal justificativa para a ausência de práticas direcionadas aos consumidores de drogas na $A B$. Como mecanismo de alívio das angústias, alguns profissionais buscam, por conta própria, alternativas de formação, pois na conformação do processo de produção de serviços de saúde a que se vinculam não são garantidos e valorizados os espaços de formação dos trabalhadores, principalmente nas áreas não incluídas no pacote assistencial priorizado para a $A B$. Essa busca por formação técnica é movida por um compromisso pessoal em dar algum tipo de resposta a essa demanda.

Os sujeitos da pesquisa reconhecem também a importância do vínculo trabalhador-usuário como um recurso fundamental na abordagem dos usuários de drogas.

A análise da percepção que os sujeitos têm sobre a atenção ao usuário de drogas na $A B$ remete a um ciclo que vem promovendo o reforço de mecanismos que colocam a $A B$ em posição secundária para proporcionar intervenções em saúde capazes de modificar o quadro de problemas que cercam o consumo de drogas.

\subsubsection{Aspectos que contribuem para a compreensão do fenômeno do consumo de drogas na contemporaneidade por parte dos trabalhadores da AB}

Neste tópico iremos analisar os fatores que estão imbricados na forma como os profissionais de saúde da $A B$ apreendem e 
interpretam em seu cotidiano o fenômeno do consumo de drogas na contemporaneidade. Quando este profissional elege como objeto do seu processo de trabalho o usuário de drogas ele se utiliza de algumas concepções que possui acerca deste objeto para recortá-lo. Tais concepções são adquiridas ao longo da história destes, a partir de sua formação, de sua trajetória de vida e, em última instância, a partir de suas experiências pessoais com substâncias psicoativas. São estas concepções que configurarão as práticas destes trabalhadores em relação aos usuários de drogas.

5.2.1.1 Concepções que amparam o trabalhador na identificação e recorte do objeto do processo de trabalho na assistência aos usuários de drogas.

Os sujeitos da pesquisa, no seu discurso sobre drogas e sobre usuários de drogas, reproduzem as concepções dominantes presentes no discurso corrente sobre drogas na saúde e no senso comum. Não se observam questionamentos ou análises críticas por referência às abordagens corriqueiras. (E1, E3, E6, E10).

Ao invés de usar uma droga ilícita [maconha], vamos usar uma droga lícita [ansiolíticos] que dá pra você... é que tá fazendo falta mesmo, ele tá precisando. Ele descobriu uma medicação pra ele. Olha, com isso eu consigo manter meu, minha vida, então você encaminha (para psiquiatra). (E1)

Como é que a gente trata um paciente de saúde mental ou de qualquer outra enfermidade, sendo ele o usuário de drogas? Que tipo de medicação? Qual é a lógica dele continuar tomando essa ou aquela medicação, sendo dependente de álcool, ou já está usando uma droga mais pesada. Efeito do que, né? (E3)

Ah, eu perguntava se eles queriam ajuda, passar no posto. Ser encaminhado para o CAPS, mas eles falavam que não, eles queriam ficar daquele jeito. $E$ quase nenhum deles passava em consulta médica também. Era complicado. Poucas pessoas passavam em consulta que moravam nessa cracolândia. Muitas vezes as pessoas iam morar lá e não tinha comida, não tinha lençol. Eu 
Heloisa da Veiga Coelho

fazia coleta nas portas para ajudar. Aquilo é necessário. Quando eu vejo que uma família que está precisando, eu mesmo vou lá e pego do meu e ajudo. (E6)

O que eu pediria para ele [prefeito] fazer é para que eles olhem mais para os usuários. Assim, com olhar clínico, de ajudar eles, entendeu? Porque no Pernambuco, eu não sei se é Pernambuco ou se é no Rio Grande no Norte, tem uma delegada que trabalha só recolhendo as pessoas usuárias da rua e coloca num internato, entendeu? E ta dando certo, porque muitas pessoas que ela já internou, ele já não usa mais droga. Porque o "usar droga" não é assim... Tem muitos que pedem ajuda, tem outros que eles pegam e levam. Ás vezes as pessoas não querem nem ir e eles levam. Passou no repórter, nem lembro qual foi o programa. Porque você usa droga, fica internado três meses, você sai e fala assim: Ah! 'eu não vou usar mais'. Não. Venci mais um dia. Porque você nunca pode falar, 'Ah, hoje eu não vou usar'. Hoje eu não tenho crack. Não. Você tem que falar: 'Nossa, hoje eu venci mais um dia'. Entendeu? Foi isso que a minha sobrinha falou para mim. Eu ligo para ela todo dia para saber dela, né? E ela falou, "Tia, to vencendo mais um dia, tia" (...) Eu pediria mais clínica, né? Clínica pelo SUS para poder internar essa pessoa. (E6)

Acho que sim [tráfico é que impede a $A B$ de desenvolver trabalhos na área de álcool e drogas]... Além desses fatores tem, a UBS é aberta... Eu acho que ela [UBS] é aberta. Pelo menos as que eu passo. Aqui ela é aberta. Até mesmo em grupos e tudo mais. Tem enfermeiras que vão fazer as medições de pressão nos bares, pra abranger essa população do álcool, pra não deixar de fora. Então já que eles não vão até o posto vamos até o bar, e o dono do bar deixa. (E10)

Acho que é o crack [droga mais problemática]... Tem bastante [usuários de crack] pelo que as equipes falam. Cocaína e crack, pelo que os agentes falam. Aparece maconha, mas até mesmo elas falam: Ah maconha, não é tão importante. Mas quando falam pra elas: Ah, mas ele já tá fumando crack. Então já tá bem avançado. (E10)

É resolutivo [atendimento das demandas de álcool e drogas na UBS] na medida em que o usuário segue as orientações. Se ele consegue seguir é 
Heloisa da Veiga Coelho

resolutivo, senão, acaba sendo resolutivo porque o objetivo foi feito. Atendemos. Foi feita as orientações, a equipe ficou matriciada. (E10)

Os trabalhadores (E2, E4, E5, E6, E7) reproduzem em seus discursos os estigmas relacionados aos consumidores de drogas, estes engendrados na sociedade há muito tempo. O usuário de drogas é considerado incapaz, fraco, indefeso, doente, marginal, desviante. Em suma, um "caso perdido" que não valeria ou não se beneficiaria de nenhuma prática porque quando a pessoa usa não tem consciência, né? (E4) e porque eles (os usuários de drogas), no momento em que precisam, eles vão aceitar o que você tiver pra oferecer pra eles (E2).

Então, é que não adianta ter a formação. É legal esse grupo de saúde mental, mas eu acho que a gente tinha que talvez, alguém lá no CAPS tinha que acompanhar esses casos. A gente não podia deixar escapar o caso, porque 0 usuário de drogas, ele vai escapar de qualquer forma. (E7)

Quem bebe constantemente não se considera alcoólatra. Fala mesmo - o dia que eu quiser parar eu paro. Mas aí você pergunta - se você tiver que tomar um antibiótico, sete dias, e aí não pode ingerir bebida, você consegue? - aí muitos não respondem. Ficam pensativos. Daí o que eles fazem com o medicamento? Eles não tomam. (E2)

Porque, por exemplo, pro cara, ele tá ali em um momento em que ele quer usar, aí ele tá tentando brigar. Ele não vai ter cabeça de ir até... Porque imagina... Porque até chegar no ponto de ônibus ele vai passar por uma biqueira ou vai passar por algum amigo, algum colega que vai oferecer, porque ele tá aí, todo mundo ajuda. Um ajuda o outro. Então ele não vai chegar até o ônibus, tentar dirigir até, ele não consegue... (E2)

Porque ele não tinha consciência do que era certo, o que era errado. Era muito difícil. (...) Mas como que uma pessoa nessas condições, não tem noção do que tá fazendo, ele vai ter noção de vir até o ambulatório? (E4) 
Heloisa da Veiga Coelho

...muitas vezes a pessoa quer sair daquilo, mas o desemprego, ele não consegue trabalhar, ele não tem caminhos alternativos, ele quer mas aí, ele pra esquecer de todos os problemas ele usa droga. O problema é tanto que é difícil segurar, né?, É tudo associado, mesmo o usuário, quem é que vai dar emprego pra um usuário? Como é que ele vai trabalhar se ele é usuário, ninguém vai dar credibilidade pra ele. (E4)

Resolve em parte, quando o familiar tá disposto a levar esse paciente num CAPS, por exemplo, porque ele não vai sozinho, com as próprias pernas dele é muito difícil ele ir, porque geralmente não é a vontade dele, de estar indo lá, é a família. (E5)

Eu acho que a família não tem que pedir ajuda pro doente, porque ele é um doente, né? O usuário de álcool é um doente,né? (E5)

Ela [filha] já fazia coisa errada, ela já vivia no mundo das drogas. Não assim no mundo das drogas, usando drogas. Ela vendia drogas lá na Praça da Sé, né?! Ela saia do colégio, falava para vó que ia passear com as colegas e ia para praça da Sé visitar os maloqueiro que fica na Praça da Sé. Não é bem maloqueiro, os usuários, né?! (...) Botei ela de casa para fora e falei, 'Aqui eu não quero mais você na minha casa'. Minha filha tá querendo me roubar, não quero. Essa é minha vida, ta? (E6)

Um dos entrevistados (E6) desenha o "perfil" do usuário de drogas, conforme o aprendizado que obteve na convivência com estes usuários. Mas não consegue romper com o senso comum e fazer uma análise socialmente ampliada do consumo de drogas.

Eu já vi o dia da pessoa como é que é. A gente tem um olho clínico, entendeu? Já conhece as pessoas pelo jeito que usa droga. (...) O perfil de quem usa maconha, a pessoa fica um pouco sonolenta e os olhos ficam meio vermelhos. E o perfil da pessoa que usa cocaína ou ele fica passando a mão no nariz direto ou ele fica se mordendo. Tem muitas características, tem uns que ficam no canto quieto, tem os que bebem, em muitos que brigam muito. Gente que bebe e é usuário cocaína. A característica é essa. Era o que eu via lá na favela Alba, aonde eu trabalhei, lá foi aprendizado para mim, ta? Conheci muitas coisas que eu não conhecia. Para mim foi aprendizagem. E quando 
Heloisa da Veiga Coelho

cheguei aqui também foi até melhor pra mim, porque eu não tinha dificuldade de lidar com pessoa. (E6)

No equacionamento da questão relacionada ao consumo de drogas, os profissionais de saúde (E4, E5, E7, E9, E10) trazem para a análise do fenômeno a questão da culpabilização do sujeito. Esta culpabilização torna-se central nos discursos dos trabalhadores, que depositam no usuário de drogas toda a responsabilidade em relação ao consumo de drogas, ao tratamento e, por último, ao sucesso ou fracasso em sua vida. Aspectos relevantes em relação ao fenômeno como a inserção destes sujeitos nas relações de produção e de consumo não são considerados pelos trabalhadores ao analisar tal questão.

Eu vi que em todos os casos que a gente teve, é assim depende muito da consciência de cada paciente, se ele quer parar. Tem muitos que vem e não quer parar não. Tem paciente com alcoolismo, que alcoolismo também, a gente oferece serviço tudo, mas ele não tem interesse de parar. (E4)

...a impotência das pessoas em resolver determinados assuntos que dependem da própria pessoa resolver. Então muitas vezes não depende de nós querermos resolver, mas depende da pessoa sair daquele problema. (E4)

Tem que ter todo o conjunto, a família, a sociedade, ele, a vontade dele, mas principalmente dele, se ele não quiser. (E4)

Não quiseram ir (usuários de drogas), porque assim se eu chegar para vocês e falar assim: 'Olha, vocês querem ajuda, não querem? Eu acompanho vocês'. Mas é aquilo, eu vou levar vocês por uns dois, três dias, depois vocês vão caminhar sozinho. Entendeu? Ai depois eles não voltaram não. Não quiseram mais voltar. (E6)

Até porque o limite da gente é bem o que o outro quer, né? Eu não posso ir além... se aquele paciente não abrir a porta pra mim não tem como eu entrar? Então você tem que pensar no seu, os nossos limites são todos pra essas 
Heloisa da Veiga Coelho

questões sociais, psicobiosociais, e a questão do livre arbítrio do outro, é o meu limite de atuação, e o sistema. (E7)

Se a família vem atrás, ele não tá aí. Ele não tá querendo,né? E a pessoa tem que querer na verdade.(E5)

A partir do momento em que a pessoa está conscientizada que ela quer aquilo pra vida dela, ela vai ter aquilo. (E5)

Eu acho que todos os casos, até mesmo fumar, que é uma droga também, o tabagismo, se a pessoa não quiser não adianta. (E5)

...como é uma coisa muito mistificada, ainda muito carregada, o pessoal... vai todo armado pra esse negócio [CAPS], acho que ele [usuário de drogas encaminhado ao CAPS pela equipe] pensou. Ele ficou com medo também, eu não sei se ele ficou com medo também de como as pessoas iriam encarar ele, de como ia ser... (E5)

A gente reclama de barriga cheia, pra quem tem tudo, tem família, tem emprego, tem proteção, tem tudo, e as vezes a gente se desespera com nossos problemas, imagina eles, que não tem nada, literalmente e nem força de vontade pra arrancar. (E7)

Porque o fundamental de todo tipo de tratamento, na minha avaliação, é a pessoa querer, que tenha a vontade. Então esses que já tem, estão predispostos, esses mesmos estão sensibilizados pra parar. (E9)

Como eu falei pra você, ele [usuário de drogas] realmente vem pra dar uma satisfação, eles não estão minimamente interessados, eu acho que não volta nem pra segunda consulta. (E9)

Qualquer que seja a resolutividade de alguma coisa vai depender do paciente, entendeu? Querer. Chegou, ele vai se tratar no CAPS, que tem agora, ou no CAISM ou na unidade. O fundamental é o paciente querer. (E9)

Aí depende do usuário, infelizmente depende dele. (E10) 
Para além da culpabilização do usuário de drogas, o trabalhador de saúde (E4, E5, E8, E10) também responsabiliza/culpabiliza a família (especialmente a chamada "família desestruturada") pelo problema das drogas na sociedade, reproduzindo o discurso simplista do senso comum e a forma hegemônica e rasa de avaliar o fenômeno do consumo de drogas. Consideram que ás vezes o problema familiar é muito maior que as nossas orientações (E4).

Acredito que é o desarranjo familiar, até mesmo as questões sociais mesmo. Companhias, alguma carência familiar, o que falta dentro de casa vai procurar fora e encontra na droga, na bebida, as companhias da escola, que tá sempre mais próximo. (E10)

Por conta de ser um problema global [o consumo de drogas]. Se a estrutura familiar não for adequada, não estiver bem estruturada, ele sozinho não consegue sair dali. (E4)

Eu percebo, porque o problema daqui é que é muito social, entendeu? Tem que ter um envolvimento da família e a família não quer se comprometer. Se comprometer é muito difícil. Cada um tem sua vida, tem sua casa, sabe? A gente até entende isso, sabe? (E5)

É uma família desestruturada [de um usuário de drogas]. A mãe dela até um certo ponto ajudava, apoiava, tentava. Mas sabe aquele negócio de desistir, de não tem mais jeito. Ela não tem mais solução. Mas é uma família um pouco desestruturada também, isso frustra a gente... (E8)

Não diria que é responsabilidade toda da família. É mais na parte social do acompanhamento, né? Porque tem pessoas que são muito vulneráveis nessa época da vida dela, porque ela depende, esse moço que eu te falei, tem que levar ele no carro, imagina! Sabe? Então, é muito difícil mesmo, sabe? Tem que ter um envolvimento social, trazer comida, dar o remédio na hora certa, é nessa parte que a família entra, acho que na parte do tratamento mesmo participação no CAPS assim. De ir em consulta, não precisa de acompanhamento. (E5) 
É complicado [atendimento da demanda de drogas] assim porque depende de toda a família, porque a família toda acaba adoecendo, e é bem difícil, acaba sendo difícil, mas não impossível, a gente atende, a equipe toda atende, às vezes a gente consegue, tem casos exitosos, já teve casos exitosos. Outros não. Mas a gente vê outras famílias que não tem essa mesma força ainda, né? A gente sabe que é possível. (E10)

O medo (do tráfico, da violência e das drogas) que povoa o senso comum é apontado pelos trabalhadores como um fator limitante na produção de intervenções em saúde direcionadas aos usuários de drogas e no acesso dessas demandas na UBS. Alguns dos trabalhadores (E1, E7, E9) que levantam essa questão procuram contextualizar esse medo referenciando-o à realidade concreta do narcotráfico no território onde atuam.

Medo, né? Porque qual é o problema se eu der... por exemplo, eu não acho que a gente vai trabalhar com o tráfico. - Olha, não faz tráfico. Não é isso. Mas qual é o problema deu morar perto e saber que ele usa droga e oferecer pra ele vir na unidade, pra ele começar o auto-cuidado? - Vamos lá, você vai fazer uns exames, vai passar com o médico, vai medir a pressão. Não é acolher? Trazer? E qual o problema de você ser vizinho? (E1)

...a gente propôs que fizéssemos um trabalho de prevenção, só que assim eu não vou me meter a falar de álcool e drogas na comunidade, assim, entendeu? Assim, vou lá e vou falar: Vou fazer um grupo pra quem quer saber mais sobre álcool e drogas. E aí já tem que ter uma coisa, não pode ser direcionado, tem que ser um negócio bem trabalhado, tem que ter toda uma estratégia. E assim, é uma comunidade que tem traficante também. Isso também, eu acho que foi um dos motivos que eles evitavam falar no assunto também. Mas assim, pra mim isso não impossibilita o trabalho. Mas a gente tinha que fazer alguma coisa voltada pro jovem e que focasse o conjunto. E aí a gente até fez alguns trabalhos assim de ir na comunidade e discutir um pouco, mas aí agora a gente parou. (E7)

...o álcool, mas mesmo o álcool e droga tá intimamente associado, ou na fantasia de todos, à criminalidade, a bandidagem, entendeu? Os agentes 
Heloisa da Veiga Coelho

comunitários são pessoas que moram na região, né? Eu acredito que tem muito a ver com o medo. O que que você quer? Tá cutucando, o quê? O que você quer se metendo com aquela fonte de dinheiro, entendeu? Eu acho que passa por aí, tem um negócio chamado medo. Os usuários chamados de noinha, de nóia são pessoas que impõem o medo na região. Real ou fictício a gente vê. Não precisa conversar com os agentes, a gente conversa com os outros usuários daqui, os outros pacientes, invariavelmente eles têm receio de lidar com esse pessoal. São pessoas que impõem medo, transmitem medo, porque eu acho que se você for perguntar talvez por aí você encontre a dificuldade dos agentes. (E9)

Outros sujeitos da pesquisa (E2, E4, E8, E10) trouxeram também o medo como uma dos principais motivos da ausência de práticas direcionadas aos usuários de drogas na $A B$. Porém, desta vez, trata-se mais de uma reação irracional, sendo pouco desenvolvidos os aspectos que poderiam explicar esse temor.

...o profissional fica com medo do que o paciente pode fazer e o paciente tá desesperado. (E2)

Tem aquele lado profissional, que a gente tem que ter a postura, mas tem o lado que a gente fica com medo, e se ele realmente fizer alguma coisa com a gente, do jeito que o paciente vem é assim difícil. (E4)

Assim, eu fico meio receosa de abordar eles quando minha ACS também não conhece muito bem. A gente sabe que tem na área. Ás vezes estão na rua. Eu fico um pouco receosa de chegar e sair perguntando. Até se ela conhece, sabe como é que é, conhece a família, como que se usa, qual o perfil. Se ela não tem essa informação eu tenho um pouco insegurança sim, de chegar, de abordar. Em VD, quando eu to na rua em VD. (E8)

Não, não é muito fácil não [abordar o tema de drogas no cotidiano]. Tanto é que, a meu ver, eu vejo que eles têm algo muito assim meio que até meio assustador, por conviverem na área. Acho que por morarem na área acho que eles têm medo até mesmo de trazer o caso pra reunião de equipe, até mesmo por sofrerem algum tipo de repressão, alguma coisa assim. Tanto é que 
grupos educativos na área pra drogas não podem acontecer, porque tem a questão do traficante. É por isso que eles ajudam quem procura eles. (E10)

A demanda que não tá conseguindo [chegar na UBS]. Acho que a própria violência. Porque eles não chegam, uma porque está totalmente envolvido, não conseguem sair pra ver que precisam de ajuda, né? Os traficantes não deixam mesmo sair. Os que querem ajuda vêm, mas também não conseguem chegar até aqui. Acho que essa questão do tráfico mesmo de ser mais forte. (E10)

A reprodução dos estigmas e preconceitos relacionados ao consumo de drogas por parte dos trabalhadores da $A B$ (E2, E3, E4, E5, E8, E9) delineia também algumas das justificativas destes para a dificuldade de acesso de demandas relacionadas ao consumo de drogas e ausência de práticas dirigidas aos usuários de drogas neste nível de atenção. Estigma e preconceito são considerados pelos trabalhadores como externos às práticas cotidianas dos trabalhadores. Acho que não é uma questão dos profissionais que estão envolvidos, acho que é uma questão estrutural mesmo. É o desenho da coisa. (E3)

É porque tipo, a bebida, o álcool, é visto como uma diversão, uma coisa do momento que você vai relaxar. A droga ainda não, porque acho que a droga assim é muito feia. Quem faz isso normalmente é marginalizado. Quem faz isso é ladrão, ou rouba, ou mata, essas coisas. Então, quem muitas vezes, não relata por causa disso. Quem relata é aquele que é o usuário há muitos anos, é aquele que usa todos os dias e não está nem aí pra vida. Ele não se importa com a opinião dos outros, mas quem tem a preocupação com a propriedade dificilmente vai relatar. (E2)

É, é a lei da oferta e da procura. Eles procuram uma coisa que tá mais fácil, e o que tá mais fácil não é a ajuda pra eles, e o meu ponto de vista é esse, não é a ajuda, e sim a droga, que tem vários pontos que tem. Aí você vê que tem milhares de pontos de droga...(E2) 
Heloisa da Veiga Coelho

Geralmente nas reuniões de equipe a gente debate (demandas relacionadas ao consumo de drogas), só que assim, dá a impressão que o tema em si não tem muita coleção.Ás vezes, porque assim, ele não quer ajudar, não quer ser ajudado. Então não adianta a gente tentar fazer com que ele mude. Deixa sempre ficar em um segundo plano.(E4)

... e não vejo muito uma grande população com esse problema de... assim, uso crônico abusivo, a gente sabe que tem uso mais moderado, mas assim crônico abusivo, totalmente dependente, eu sei que não tem muito, é um caso ou outro, mas é uma área tranquila em relação a isso. Eu sei que tem outras áreas em que o foco maior é o usuário de droga... Então tem essa vantagem que na minha área não tá tão explicito isso. Mas eu sei que não tem nenhum local de tráfico que a gente tenha conhecimento, comunidade. Não tem nada disso. Mas tem um vespeiro que a gente tem que mexer. Uma hora vai ter que mexer. (E8)

...como é uma coisa ilícita a pessoa mascara muito, né? A pessoa mascara. É mais fácil ver se tá tudo bem, mascarar e dizer que tá tudo bem, não tocar no assunto do que tocar no assunto. (E5)

Não, imagina [questiona os moradores de sua área sobre o consumo de drogas]. Uma porque eu moro na área também, né? É difícil pra gente, né? Vou tocar no assunto??? É complicado, entendeu? Aí é um tratamento que eles não deixam. Já mudam de assunto, entendeu? (E5)

Tem, nossa, tem [espaços de discussão sobre drogas na equipe]. A gente discute, mas aquilo lá que eu te falei, a gente fica de mãos atadas. Primeiro a gente mora na área, o principal disso é que eles não abrem o jogo pra gente, a gente sabe que é usuário tudo porque a gente vê, entendeu? Eu vejo esse menino usuário de crack, irmão desse meu psiquiátrico lá na favela comprando também... Mas assim, eu não sei se eles têm medo, também. Tão cansados do sistema como é, eu não sei. Eu não sei o que acontece... Na equipe a gente até tem vontade. A gente tem muita vontade de fazer, mas fica com as mãos atadas por conta disso. (E5)

Então deve ser umas 50 famílias com esse problema, e fora os que são mascarados que não falam de jeito nenhum,né? Nem pelos vizinhos nem por ninguém. Porque as pessoas tem essa coisa de que ah droga, de droga não 
Heloisa da Veiga Coelho

vou nem falar, o usuário coitado. Tem o preconceito que a pessoa tem. Ás vezes eu não sei o quê que acontece. Não sei o que acontece mesmo. A gente fala que não [tem preconceito], mas não sei até que ponto. (E5)

A partir do momento que esse tema for mais desmistificado, eu acho que vai ser mais fácil a gente lidar com ele. Porque o necessário pra gente lidar com esse tema é vontade de lidar com esse tema. É a própria vontade da gente de trabalhar com esse pessoal, entendeu? A partir do momento que você tem vontade de trabalhar com esse pessoal se torna mais fácil a coisa. A coisa já é mais diluída. Não sei se é essa a palavra certa, né? Mas assim, mais fácil de você falar sobre isso, né? Agora como se você tá desarmada, né? Quando você desarma a pessoa, né? A gente mesmo eu digo, né? Você falou sobre se eu tenho preconceito, né? Eu não sei, viu? Boa pergunta, viu? Eu nunca parei pra pensar nisso, sabia? A gente fala com o filho, igual eu falo com a minha filha tudo, mas eu nunca parei pra pensar sobre preconceito ou não. (E5)

...o agente ser da região, ser vizinho, é absolutamente um empecilho para cobrar do pessoal, usuário de droga mais, porque álcool, ser alcoólatra não causa mais transtorno. É aquele bêbado que todo mundo conhece, o bêbado da região, que já deixou de ser bravo, de tanta cachaça que tomou não causa mais. Agora o usuário de droga, que é invariavelmente jovem, é difícil você ver um velho. (E9)

Há alguns sujeitos da pesquisa (E2, E3, E4, E7, E9) que apresentam um posicionamento crítico em relação ao fenômeno do consumo de drogas, conseguindo analisar a questão a partir de um prisma mais ampliado, que leva em consideração as dinâmicas sociais. Tal percepção ampliada do fenômeno provoca questionamentos neste trabalho sobre os motivos que não permitem que todos os trabalhadores apreendam o objeto das práticas relacionadas ao consumo de drogas de forma crítica.

Às vezes o socioeconômico é muito maior que as orientações. E como a gente não consegue resolver muito essa parte social e econômica eles continuam. (E4) 
Heloisa da Veiga Coelho

...na minha área tem cinco bares, uma rua cinco bares. É que também assim aqui no bairro não tem muito lugar pra você ir, então pra eles é o bar. (E2)

Então tem que mostrar que existe um outro caminho, outros objetivos de vida, então talvez ele consegue.(E4)

A pessoa que tá usando droga geralmente, ou é porque ela está procurando um tipo de prazer ou é pra suprir alguma necessidade, as vezes é porque tá passando dificuldade. (E2)

Se a gente não entende que essa é outra questão que está na relação. Seria tão mais fácil, né? Passar a receita, dar o remédio, tomar a pílula e tá curado. Não é. Embora a gente tende a transmitir um pouco essa ilusão. De que quando ela fala da internação, ela acha que já é um sofrimento tão grande, eu quero tanto acreditar que nesses próximos seis meses que ele vai estar internado... Tem um termo que a gente usa que é limpar. Ela vai pra lá, ela vai ficar limpa, e aí ela vai voltar e tudo bem. Agora, o que ocasionou aquilo? Porque que ele chegou naquilo? É o uso da droga, do álcool, seja do que for. O quê que aconteceu naquela vida, naquele espaço físico, com aquelas pessoas, que fez com que... Isso não se questiona? Será que eu me questiono se você tem uma atendimento pro cara? Eu digo pra você porque você não vai lá porque você não quer. Não é mesmo? Aliás, não é nada fácil... (E3)

Até que ponto esse profissional percebe a realidade em que ele está inserido profissionalmente, entendeu? Eu estou aqui, em uma comunidade carente, a minha área é a área que mais tem casas de invasão. Eu tenho uma violência a mais... existe uma violência na comunidade. Existem muito usuários de drogas, existem muitos casos complexos, em todas as áreas, em todos os dados. Vamos dizer assim, eu sei que existe e eu sei que a gente faz, ás vezes até muito, entendeu? Mas que, talvez, teria que ser muito mais, entendeu? Aí você tem que ver até que ponto o profissional percebe isso, né? Porque tem uns que dão só receita e que ás vezes não tem essa sensibilidade, de perceber a dinâmica familiar, a dinâmica social, a questão da violência, a questão da desigualdade social, da falta de oportunidade que desencadeia uma série de coisas, do conhecimento, do grau de instrução, que é comprometidíssimo. (E7) 
Heloisa da Veiga Coelho

Eu enxergo as coisas de fora com um pouco mais de, sem tanta ilusão de que você vai salvar o mundo, porque você na área de saúde é isso que você pensa... porque eu não vou resolver o problema dele. (E7)

Assim, ás vezes eu fico pensando assim, não é culpa do sistema de saúde só. Na mente da gente é ruim, mas é todo um contexto. Ás vezes a gente... vamos supor que ele recebeu o melhor dos atendimentos, faz o acompanhamento lá com a psicóloga do CAPS que é muito legal, que escuta ele, ele tá tomando a medicação, o psiquiatra avaliou e tal. Mas ele chega na casa dele, ele é vítima de violência, ele não tem emprego, não tem perspectiva. Dentro da casa dele há outros usuários de drogas. Acaba sendo muito difícil tirar essa pessoa mesmo, o contexto social dela é muito ruim, não é só a saúde. [Ele tem de conviver com outras coisas também - ENTREVISTADORA] $A$ saúde está de vítima nessa história também, porque não é só... ah! vamos resolver o problema da drogadição. Não. As outras instâncias também tem que fazer e não é só o judiciário que tem que prender ou tem que fazer, não tem que fazer um trabalho de prevenção, prevenção de cidadania, prevenção de garantir os direitos básicos de dignidade, e aí sim se essa pessoa vai conseguir, aí sim. (E7)

E aí a saúde vai fazer o quê? Não tem como fazer. Não tem como você curar uma sociedade que não tem educação, que não tem moradia, que tem essa desigualdade social tremenda. Isso não é só a saúde sozinha que vai resolver, eu acho que assim, as pessoas elas não percebem que assim, bem cada macaco no seu galho mesmo. Isso tá como o muito bem feito. Se outras instâncias não funcionam a saúde é a que menos vai funcionar. Podem colocar uma tropa de psiquiatras, psicólogos, serviço social e enfermeiras bem intencionados não vai resolver. [Tem que mudar - ENTREVISTADORA]. A questão é estrutural, é igual criança na escola. É igual educação. Criança chega da escola, não tem o que comer em casa, sofre violência do pai e da mãe, e aí querem que a criança aprenda, querem que a criança seja um ser humano que colabore com a sociedade, que traga bom, como?... aí esse menino vai virar um pré adolescente usuário de droga, e aí ele vai ter que roubar na vida, aí vai pegar uma arma e vai te apontar no farol, e talvez te mate, porque ele não tem nada a perder, aí assim o quê que a saúde pode fazer? Ele é o vilão. É mais um menino que é um vilão. Então eu vejo assim, sabe? Vejo que não é uma coisa que a saúde vai resolver sozinha. Aliás, como inúmeras das questões não só da juventude. As outras instâncias tem 
Heloisa da Veiga Coelho

que funcionar bem, tinha que articular essas instâncias, tá? Como você falou, o MP tá atolado de questões críticas pra cuidar, então ele não consegue ver o que poderia fazer pra prevenir essas questões. Então assim, tá todo mundo atolado, num mar de lama ... É triste. Se você for parar pra pensar é deprimente. (E7)

Na verdade é como se a gente tivesse enxugando gelo, porque a questão da drogadição não é uma questão puramente de saúde, não é como, vamos dar um exemplo, alguma coisa que a gente trata com medicamento $e$ passa,entendeu? Que nem as doenças são assim, aquele olhar de saúde coletiva tem todo o contexto, imagina a droga,né? E qual que é a característica da droga? Inserir aquela pessoa no meio. Ele se droga pra se sentir mais atuante, pra se sentir, não é? Não tem aquela questão? Pra escapar dessa realidade. (E7)

Quem nós vamos responsabilizar, o usuário? O sujeito está ali ele não vai porque ele não quer?Não é? Eu acho complicado, porque nesse caso em especial... Vejo um pouco também em termos de saúde, né? Pra vir com muita dificuldade ele tá aqui. Ah! O paciente não vem em consulta porque não quer. Só quer ficar passando em consulta só quando está doente. Não quer fazer um acompanhamento regular, preventivo, nem quer tomar remédio. Na hora que o negócio bate, aí vem aqui que nem louco, quer brigar com todo mundo. Ah! Tudo bem... Vamos responsabilizar quem de fato é. A responsabilidade é... O agente tem que criar de fato um acesso, a gente tem que permitir, não digo nem facilitar no sentido de dar de mão beijada, de carregar no colo, não é isso não. A gente não tem que facilitar, permitir isso? Porque se Maomé não vai até a montanha então a montanha tem que ir até Maomé. Se a gente reconstruir na nossa sociedade essa relação, esse conceito do que é a saúde, de como deve ser a saúde. A gente ainda tem que quebrar umas pedras. E eu acho que na relação aí, quem é mais frágil? É o usuário. Acho que ele não deve ser responsabilizado, acho que tem sim que responsabilizar pela sua consulta médica, pelo seu tratamento, pelo acompanhamento, mas eu tenho que dar condições para que isso aconteça. (E3)

Então, a sensação que a gente tem, a gente não tem muito o que fazer por essas pessoas, então a única coisa que a gente tem é de encaminhar pro CAPS ad. E aí é aquilo que acontece... A gente encaminha (para CAPS) e na maioria das vezes eles chegam lá, eles são triados, eles vão participar de um 
grupo coletivo, um grupo de atendimento coletivo, um grupo de acolhimento, e aí eles se cansam de participar desse grupo, principalmente os usuários de álcool, e aí eles desistem, literalmente, e ás vezes ainda quebra o pouco vínculo que a gente tem com ele. Daí eles não voltam pra cá. Essa é a experiência que eu tive ao longos dos anos trabalhando aqui. (E7)

Na verdade nesse atendimento básico que a gente faz, a gente atende muita coisa que não é exatamente um problema psiquiátrico. A gente atende muito demanda do que seria problemas sociais, problemas situacionais. Desde a mãe que o filho tá preso por droga, aí sim. Tem muita mãe de drogado que eu atendo, mas que me procura, procura o serviço mais por que assim toda a situação que ela tá vivendo, de ter um filho preso, um filho envolvido com a criminalidade que a droga levou, né? Começa a roubar em casa, aquele negócio que você já sabe, depois começa a traficar, depois a assaltar, então a gente tem muito isso, mãe, irmã, parente de drogado, principalmente o pai [drogado]. (E9)

Considera-se que estas concepções críticas que aparecem no discurso dos trabalhadores em relação ao fenômeno do consumo de drogas não se sustentam principalmente porque não há sequer meios e instrumentos compatíveis e adequados para a ampliação do objeto do processo de trabalho (aquilo que se deseja conhecer e transformar). Este objeto para ser concebido amplamente, a partir de categorias sociais que explicam melhor o consumo de drogas na sociedade e nos diferentes grupos/classes sociais, necessita de um conhecimento aprofundado das formas de viver e trabalhar dos diferentes grupos sociais que vivem em determinados territórios.

Torna-se dominante então, entre os profissionais de saúde da $A B$ (E2, E4, E5, E6, E8), a compreensão idealizada, romântica e despolitizada da $A B$ e do consumo de drogas pela sociedade, reforçando o discurso do senso comum.

Porque eu sabia que a Prefeitura tava cogitando de ter um programa, que era o PSF, aí eu falei assim o próximo programa que tiver, porque tinha o PAS, e 
Heloisa da Veiga Coelho

esse PAS eu fiquei com muito medo de entrar porque era tipo cooperativa, e assim, eles não me orientaram direito os funcionários, aí eu disse que o próximo programa que tivesse eu ia entrar de todo o jeito. (E4)

Eu gosto mais de atender, eu gosto mais da assistência... (E4)

Eu gosto (de ser ACS) porque assim, é um trabalho que lida diretamente com o público, sempre gostei, de ficar no meio do público, então por isso que eu me identifico muito. (E2)

Tô aqui porque eu acredito no trabalho, e a gente faz as coisas com amor, eu parto do princípio que se a gente faz as coisas com amor o dinheiro até rende. (E5)

...mas a minha vontade foi sempre trabalhar na atenção básica, no programa da saúde da família desde o primeiro ano da faculdade quando eu fui conhecer as UBS, o programa, daí no último ano de faculdade eu fiz um estágio em uma UBS, em PSF, e daí eu me encantei muito foi aonde eu realmente e aí eu tive certeza que era aquilo que eu queria... Nesses quatro anos tive algumas frustrações sim, mas nada que me fez desgostar do trabalho, do programa, a gente vai trabalhando as frustrações até porque não é só o PSF ou a atenção básica que traz essa frustração. Acho que é a saúde no geral, porque tenho amigas que... enfermeiras que a gente tem muito contato, que trabalham em outros locais, hospital, e em setores diferentes e todas tem as mesmas frustrações, mesmos anseios, mesmas preocupações, eu acho que é uma coisa da profissão também e da realidade. (E8)

Só que esse só usar [consumo esporádico de substâncias ilícitas como a maconha] a gente fala assim, não traz danos pras outras pessoas. Mas aí começou a trazer danos pra família porque ele roubava, começou a levar tudo de dentro da casa pra usar droga, largou o emprego, né? (E4)

Nem tanto, nem tanto [internação como resposta para o problema das drogas]. A internação seria bom. Mas a reeducação daquele paciente seria bem melhor. Não dá resultado [internação compulsória]. Pegando na rua a força? Não dá resultado. Dá resultado assim, se a pessoa chegar e falar assim, 'me ajuda, eu quero ajuda, eu preciso de ajuda'. (E6) 
Foi possível perceber, frente ao processo de pesquisa, que espaços de instrumentalização e reflexão dos trabalhadores sobre o fenômeno do consumo de drogas poderiam produzir insights fecundos e bastante produtivos, visto que, a simples interlocução com a pesquisadora, frente aos esclarecimentos em relação aos objetivos da pesquisa, foi capaz de conduzir a questionamentos interessantes por parte de alguns (E2, E3, E4, E5).

Essa conversa que tive com você... tinha muita coisa que vinha na minha mente. É do planejamento mesmo. Realmente não deixar a rotina do seu dia a dia virar uma bola de neve. Você ter planejamento então já marcar o grupo de apoio com os temas. (E4)

Tem que mostrar pra ela que não é só esse mundinho dela que ela vive, que ela tem condições de ser um ser humano normal, que a sociedade intitula a pessoa como se ela uma, sei lá, uma leprosa,entendeu? Não é assim. Será que é difícil entender isso? Como você disse naquele dia na reunião com a gente. Tem gente que quer documentação, entendeu? Eu achei muito legal, saber os direitos que ela tem, a pessoa não sabe, porque ela se sente excluída também. (E5)

Tá vindo um monte de perguntas na minha cabeça. Será que eu to falando nesse assunto por preconceito pra ele por isso que eles não abrem também? Tem que parar pra ver como a gente tá agindo. Tem que ver com os funcionários, com a gente, pra ver como a gente tá agindo também. (E5)

...você conversando, você sensibilizando, igual você fez na reunião com a gente, eu acho legal. De repente despertou. Esse negócio que você falou do preconceito, você desperta. Será que eu sou? Não? Entendeu? Umas coisas que ajuda a refletir a gente. (...) porque tem muita coisa que eu não sabia, né? Igual uma garrafa de pinga custava 2 reais, Eu não sabia. (E5)

[O psiquiatra] deu uma droga pela outra. Uma que vai deixar ele mais calmo, que a sociedade aceita, do que outra que a sociedade condena. Todo medicamento é droga. Todo medicamento é droga, tem medicamento que vicia. (E2) 
Heloisa da Veiga Coelho

Talvez alguns outros colegas, ou outros profissionais, não é nem a questão de não ter a competência técnica, é não se sentir a vontade, é não se sentir preparado para lidar com essa problemática. (E3)

As formas como estão organizados os processo de trabalho na $A B$ e a ausência de espaços de reflexão sobre estes processos, bem como a organização do processo de produção dos serviços de saúde em si impedem que os trabalhadores qualifiquem as demandas relacionadas ao consumo de drogas, que conseguem chegar na $\mathrm{AB}$, como necessidades de saúde. Isso gera intervenções estigmatizantes e com baixa resolutividade.

Como normalmente essas questões [do consumo de drogas] são tratadas de uma forma muito criminalizada é sempre a ideia de que eu vou perder alguma coisa então. Por exemplo, eu sou usuária de droga e tenho um filho. Se me forçarem a vir aqui eu corro o risco de perder meu filho. Eu sou usuário de droga e tenho um emprego e se meu patrão souber que eu uso drogas eu vou perder meu emprego. Se eu sou usuário de droga e vier aqui no médico e ele me der um atestado disso eu vou perder... quer dizer, é sempre esse sentimento de perda. Olha fica difícil ele pedir ajuda, dizer: Olha vc tem que me ajudar. (E3)

Não atendo muito paciente [usuário de drogas]. Os pacientes não chegam pra mim. Não vêm abertamente. Não é frequente isso (...) A gente discute quando existe o caso, quando aparece algum caso que é usuário, que a mãe pede ajuda, o pai pede ajuda, o próprio usuário vem pedir ajuda, aí a gente discute (...)Talvez por todo mundo conhecer, já saber do que se trata, já tá rotulado como rótulo. Talvez por isso, lá vem o drogado, esse cara que não tem jeito. $O$ quê que ele tá fazendo aqui? Talvez seja por preconceito. (E8)

O vínculo torna-se o principal instrumento do processo de trabalho quando o objeto é o usuário de drogas e suas demandas. Essa valorização do aspecto humano (em detrimento do aspecto técnico) na relação entre usuários de drogas/familiares e profissional da saúde permite a este oferecer algum conforto para o sofrimento dos sujeitos que sofrem com o consumo de drogas, uma vez que, 
fica muito mais difícil para eles visualizarem outras possibilidades de transformação da realidade e respostas mais adequadas às demandas a partir de suas práticas cotidianas.

E a gente acreditar que a primeira coisa é você acolher essas pessoas. Acho que assim, a primeira coisa é você acolher, você tem um vinculo com essas pessoas (...) Então, eles [usuários de drogas] falam muito claro. Acho que se eles percebem que você não tá julgando, que você tá ouvindo, que você tá interessada neles, eles falam numa boa. Eu nunca tive problema. Eu tive problema com os funcionários. Inclusive com a chefia da unidade. (E1)

...eu passo o caso pro... [psiquiatra], converso. Ele passa em consulta com o... [psiquiatra], volta comigo, fica no grupo, se ele começa a faltar a gente também tenta ligar pra saber o que tá acontecendo, fala que tá com saudade, ou vai fazer visita... vamos fazer visita... (E1)

Isso é uma coisa que a gente sempre notou assim. Eu ia lá na favela. E daí? Passa o ACS? Passa. E aí você vai lá e olha aquela casa. Tem muita coisa pra fazer. Que é acolher, né? Eu não sei se a falta de acolhimento vem só pra esse problema, né? (E1)

Geralmente porque eles me falam, alguns relatam, outros não. Aí eu acho que eles vão vendo que você vai pegando confiança, porque um ou outro fala. Porque geralmente um sabe que o outro usa, né? Aí eles vão pegando confiança e vão falando. É que eu acho que os pacientes se identificam com quem eles veem que é uma pessoa que vai parar para ouvir eles. (E2)

Aí, na época ele estava começando a aceitar o programa de tanto que eu ia lá, via ele na rua falava - E aí, você tá bem? Vamos marcar consulta - aí eles ficavam meio assim, mas pensavam - ela tá preocupada, ela se interessa - se eles sentem que você se interessa é onde eles vão se abrir mais, vão estar conversando com você. Agora se eles vêm que não tá nem aí e só tá cumprindo o serviço dificilmente eles vão se abrir (...) Porque muitas vezes é só isso que eles [usuários de drogas] querem. Eles querem é alguém pra desabafar. Aí se você parar pra ouvir eles, se você der atenção, se você não ficar torcendo o nariz nem nada é onde eles acabam relatando [o consumo]. (E2) 
Heloisa da Veiga Coelho

Mas a gente tem que garantir mais ou menos esse acompanhamento. Olha, tem um vínculo lá, o paciente não veio. Olha, vamos na casa, vamos ver o que aconteceu, vamos voltar lá, vamos falar pra esse paciente - Olha você tava indo, o fulano lá do CAPS que você sabe quem é, que construiu o vínculo, ligou pra perguntar de você, porque que você não quer ir? Se for o caso ir junto com a pessoa. Será que o usuário é "pegar na mãozinha"? A gente leva. Às vezes essas pessoas não têm família, na maioria das vezes não têm ninguém no mundo. Mas... Eu não teria tempo pra levar. Não, assim, mas eu acho que é algo que eu acho que poderia ajudar, não que eu possa fazer, eu poder já é outros quinhentos. (E7)

Não [prescreve medicação], porque aí eu não dou receita porque não houve um vínculo. E esse negócio de dar receita é quando já existe um vínculo. $O$ paciente vem sempre ou um dia não pode vir aí você dá receita para o familiar. Mas nesse tipo não, porque não tem nenhum vínculo, nem eu vou dar a receita pra família medicar. (E9)

5.2.1.2 Aspectos da formação do trabalhador que não contribuem para $O$ atendimento das demandas relacionadas ao consumo de drogas na AB.

Os sujeitos entrevistados (E1, E2, E4, E5) referem-se à formação técnica como essencial para dar conta da complexidade da problemática do consumo de drogas apontando a necessidade de (...) profissionais, assim, mais bem treinados pra lidar com isso. (E2)

(...) aí eu pedi, eu fui até atrás, para ele [docente da UNIFESP] dar um curso, um treinamento pra gente [trabalhadores do PS no qual o sujeito era gerente na época], de como lidar com usuário de droga tal. Só que depois mudou a administração e a gente acabou não conseguindo... (E1)

Então eu acho que quando você começa a lidar com o paciente a primeira coisa que você quer entender é essa parte clínica, né? (E1)

(...) porque nem sempre eles [trabalhadores] estão treinados e preparados pra lidar com o momento que a pessoa vem. Porque ás vezes a pessoa vem em 
Heloisa da Veiga Coelho

surto e aí não sabem como lidar. Fica aquela coisa tensa... [é necessário] profissional pra lidar diretamente com esse assunto. (E2)

Você tem que ter, na parte clínica, tem que ter muito jogo de cintura. Com certeza você encontra paciente que fala assim que você tem que dar orientação, palestra, mas muitas vezes ele não quer, entendeu? Não quer ouvir você. Às vezes você até atrapalha porque ele diz: Ah! Não quero te ouvir, é muita gente falando. Naquele momento não é o adequado. Eu acho que tem que ter muito essa parte prática também. Não adianta só saber quais os efeitos que as drogas fazem, como que o usuário tem acesso à droga, isso tudo a gente até sabe, as medicações que o paciente utiliza, em caso de uso de drogas, mas assim, no dia a dia, na prática, não tem como aprender isso. (E4)

Como eu não tive essa capacitação [na área de drogas], precisa desse trabalho de abordagem, né? Pra ver como é que... (E5)

Sinto [dificuldade de abordar o tema drogas com os moradores da microárea] porque eu não sou uma pessoa capacitada pra atender esse pessoal. Ás vezes não sei, se teria uma forma de abordar, não sei se teria uma forma porque ia ser até mais fácil da gente trabalhar. Eu acho que até o modo como você aborda até eles abririam o jogo. Não sei... Eu tô falando no achismo também. (E5)

Quando indagados sobre a formação na temática de álcool e outras drogas no período da educação formal (graduação, pósgraduação, ensino médio) e/ou na trajetória profissional (promovido pela prefeitura e/ou OS) muitos trabalhadores (E1, E2, E3, E4, E5, E7, E8, E9) relataram a deficiência (ausência ou insuficiência) de formação específica sobre o tema. Percebe-se nos relatos a hegemonia da formação clínica/biomédica, pautada no modelo psiquiátrico e um papel secundário da Saúde Mental, enquanto campo de conhecimentos e práticas, na formação dos trabalhadores em saúde. 
Heloisa da Veiga Coelho

E1: Nada, nada, nada. Nem a parte clínica.

ENTREVISTADORA: A parte de psiquiatria...

E1: Nada

ENTREVISTADORA: O que davam em psiquiatria ???

E1: Ah eram as psicoses, as neuroses, só que tudo muito pincelado. Nós não tivemos aula nem de psicologia na faculdade... eu fui atrás porque eu fui pra ver essas demandas, mas nós não tivemos nada. (E1)

Então na escola, principalmente no Teotônio, foi sempre muito abordado [0 tema do consumo de drogas]. Era até meio chato. Todo mês a gente tinha ou uma palestra, ou tinha que fazer um trabalho relacionado, ou os professores paravam, deixavam de dar aula pra ficar falando alguma coisa sobre o assunto, né? Entre outras coisas, era porque era muito presente lá. Então, eles geralmente quando iam falar sobre drogas eles tentavam falar tipo o quê que era cada droga. Que era uma coisa que a gente sabia. Porque o tráfico lá na minha escola era forte. $E$ aí eles tentavam explicar os males que fazia $e$ tudo mais... (E2)

Não [tiveram nenhum curso na área de drogas promovido pelos gestores]. $O$ que a gente teve foi você vir tratar o assunto. Mas até então não. No momento 1 eles falam dos parceiros, né? Que a gente faz aquele treinamento de uma semana, onde eles falam do CAPS, de qualquer caso que tiver pode estar procurando o CAPS. O que eles falam pra gente é só isso, mas uma formação pra... falando disso não. (E2)

Eu gostava muito do trabalho mais popular. Eu via um equívoco da minha própria geração, que a formação era muito fragmentada, antes dessa reforma curricular. A gente dizia assim: Serviço social de empresa, serviço social comunitário, serviço social da saúde... e eu gostava do comunitário e a minha associação, a minha visão da saúde era aquela visão equivocada que saúde era tratamento. O serviço social era muito presente principalmente nos hospitais, eu não me via trabalhando nessa área. Então, foi a geração de 82, onde a gente estava fazendo um ampla reforma curricular que impactou bastante na formação dos assistentes sociais, desde então, com uma visão mais crítica. Nós não tivemos naquela época uma disciplina específica que tratasse dessa questão [drogas]. Nós tínhamos dentro das disciplinas, particularmente em psicologia social, e depois na etapa de estágio, dependendo da opção que nós fizéssemos o acompanhamento nesse sentido. 
Heloisa da Veiga Coelho

Eu pessoalmente não. A minha aproximação com a saúde foi uma coisa engraçada porque eu sempre neguei a saúde. (E3)

Eu só tive na época da em... quando eu estava fazendo a graduação. Que agente ia em hospital psiquiátrico, mas muito pouco. Assim, e tinha a rede de psiquiatra. (E4)

Específico [na área de drogas] não. Tive várias outras capacitações. Capacitações a gente teve um monte. O que vem na minha cabeça agora é o $P A V S$ [Programa de ambientes verdes e saudáveis]. (E5)

Não conheço [a política do MS], talvez até por falta de informação, de capacitação, eu não conheço mesmo. Conheço porque você falou aqui naquele dia. (E5)

Não [teve formação em álcool e outras drogas]. O mais perto disso que a gente chegou [do tema de drogas na formação] foi na psiquiatria mesmo, que a gente atendia no hospital psiquiátrico, que era um hospital para álcool e drogas. (E7)

Na graduação não. Assim, tive o que eles tinham na grade curricular mesmo, mas extracurricular... Era mais os efeitos, fisiológico e tal das drogas, não tive nenhum tipo de contato com usuário, não fiz nenhum trabalho com eles durante a graduação... Teve um estágio uma vez que eu fiz, mas o foco não era só em usuário de drogas, era em moradores de rua e junto tinha os usuários drogas. Aí eu fiquei duas semanas lá, indo lá... e automaticamente nesse grupo que atendia tinha os usuários. (E8)

Não [não teve formação na graduação]. Eu fiz especialização e tinha uma matéria de álcool e droga, mas não era nada tão aprofundado. (E9)

Os trabalhadores E4 e E7, ao se ressentirem da ausência de instrumentos para promover a transformação do objeto de trabalho, referem angústia por não ofertarem respostas efetivas às demandas relacionadas ao consumo de drogas. 
Heloisa da Veiga Coelho

Assim, eu não tenho dificuldade de atender, mas eu tenho dificuldade de solucionar, de ter um encaminhamento pra esse paciente, uma resposta. Porque às vezes, a gente encaminha, a gente sabe o fluxo, né? Só que, assim, dificilmente ele vai... (E4)

Eu me incomodo muito de não conseguir resolver essas questões. Eu sei que não depende de mim. (E7)

Este incômodo mobiliza alguns trabalhadores (E1, E4, E8, E10) na busca por formação. Eles identificam a necessidade de formação para ampliar as práticas voltadas aos usuários de álcool e outras drogas.

Como tudo que eu faço e, assim, atender os adolescentes foi uma coisa super-rica para mim. Eu quis estudar mais. Eu acho que estimulou a estudar outras coisas. Assim como quando eu fui para o ambulatório de AIDS acho que me estimulou a estudar, ver o outro lado e até entrei em contato um pouco com as questões dos usuários de drogas como com as mães que eram prostitutas e acho que eu aprendi muito não só da parte técnica, da parte médica, mas do ser humano. Então foi super-rica essa experiência de trabalhar lá no ambulatório de AIDS. E como as crianças do ambulatório de AIDS cresceram, viraram adolescentes eu fui fazer especialização lá na UNIFESP para hebiatria... E comecei a atender os adolescentes. E aí aos poucos eu fui fazendo cursos para aprender a lidar (E1).

Eu mesma, eu realmente eu fiz o curso que era "Uso indevido de drogas para líder comunitário". Eu sabia tudo, de todas (...) Então, é um livro super interessante. Você tem consciência de todos os efeitos colaterais da droga. Mas assim, na prática... (E4)

Mas pensando nisso, nessa falta de paciente. Eu sei que tem pacientes usuários na minha área e pensando na minha pouca preparação pra isso, no começo do ano eu fiz aquele curso do SUPERA que é online. Até acabei de receber um certificado e aquele teste que eles pedem pra gente aplicar (...) eles até mandaram umas folhas avulsas pra gente fazer. Eu achei muito interessante e aí eu pude ver de verdade a forma e o meu despreparo (...) Teve um tópico de abordagem, outro de diagnóstico, tinha a questão social, 
Heloisa da Veiga Coelho

como ir acompanhando esse usuário, vendo a rotina do CAPS, a fisiologia da droga, a cultura de cada droga. Foi bem legal, foi interessante.(E8)

O que chega do caso, o que é falado do caso a orientação é principalmente para os agentes. São as orientações (...) eu fiz curso do SUPERA. Então algumas vezes dá pra gente intercalar (discussão de caso) com alguns conhecimentos (...) Não dá para usar sempre, porque a teoria é bem intensa, mas dá pra gente ter uma ideia até mesmo para abordar (...) Pra discussão do caso dá até pra gente abranger a questão do uso abusivo, o que é uso abusivo, o que é, vamos supor, beber socialmente, o que já ultrapassou, tudo mais. Pra gente levar pra elas (ACS). Tá bebendo mesmo? (...) Há um matriciamento, onde tem toda equipe, inclusive na reunião a gente acha muito importante que as ACS tenham esse conhecimento. Até mesmo pra lidar com isso na área. Porque às vezes pode ser um vizinho, até mesmo dentro da casa dela, né? Então a gente faz esse matriciamento para que elas tenham esse conhecimento até mesmo para lidar. Como lidar, como se comportar até, né? (E10)

A ausência de formação também aparece como uma das justificativas do não atendimento às demandas relacionadas ao consumo de drogas, pois, às vezes, a droga vai ficando em segundo plano, porque a gente tem dificuldade de lidar. Então, pode ser isso porque a gente vai deixando em segundo plano, que é um tema importante. (E4)

Mas pensando nisso, nessa falta de paciente. Eu sei que tem pacientes usuários na minha área e pensando na minha pouca preparação pra isso, no começo do ano eu fiz aquele curso do SUPERA que é online. (E8)

Então precisa de um treinamento, [para melhorar a abordagem dos ACS em relação aos usuários de drogas], alguma coisa. Mas eu também fico pensando em que tipo de treinamento? Mas agora com o SUPERA eu posso ter alguma ideia (..). Acho que um treinamento assim, uma orientação, um treinamento teórico e também acompanhar eles (ACS) na prática. Porque não são profissionais da saúde que tiveram todo o conteúdo que a gente teve. Acho que é um pouquinho mais difícil para eles. Acho que eles têm que ter uma preparação de como abordar. É difícil de cobrar isso deles, porque a gente sabe que eles não foram preparados (...) Nos quatro anos que eu estou aqui 
Heloisa da Veiga Coelho

não [profissionais não tiveram nenhum tipo de formação na área de drogas]. (E8)

Talvez um pouco de falta de treinamento dos funcionários na abordagem dos usuários. Eles (usuários de drogas) até chegam, mas as barreiras estão aqui dentro. Pode existir uma barreira aqui dentro, por preconceito, por algum outro motivo. Não saber abordar mesmo. Eles acabam, começam a ter o acesso interrompido já aí. Talvez eles não se sintam a vontade também de vir pra cá, pra essa unidade, pras unidades. (E8)

Voltando ao negócio [dificuldade de abordagem do tema de drogas pelos ACS], eu acho que há uma dificuldade. Primeiro, os agentes acho que não tem nenhuma, não é nem formação, não tem nenhuma informação sobre como abordar.(E9)

Quando alguns trabalhadores (E4, E8, E10), que realizaram formação específica na área de drogas, foram questionados sobre possíveis mudanças nas suas práticas a partir do curso, estes apontaram que mudanças significativas não aconteceram no seu cotidiano a partir do curso. Eles atribuem o pequeno impacto dessa formação à ausência de instrumental "prático" que ensine como abordar os usuários de drogas. As limitações dessa formação técnica requerida, de caráter clínico, não são aventadas no discurso. Fica dessa forma parecendo que o fenômeno do consumo de drogas seria bem atendido pela saúde se o requerido instrumental clínico fosse disponibilizado aos trabalhadores que estão na $A B$. Assim, o tipo de formação que extrapola o campo biológico e inclua aspectos sociais e humanos não é uma questão por eles analisada.

Eu tenho atualmente [após a formação] um pouco mais de paciência, não tenho tanto medo de lidar. Eu estou respeitando, mais assim, a vontade deles, como usuários. Realmente eu estou sabendo lidar um pouco mais, mas na prática é super difícil. Como você vai conseguir segurar uma pessoa que tá drogada? (E4) 
Heloisa da Veiga Coelho

Assim, acho que só faltou uma parte prática, porque lá é só teórico, faltou um pouquinho a parte prática, mas já foi legal, e foi através desse curso que eu percebi como eu faço pouca coisa em relação a isso,entendeu? Caiu minha ficha. Eu ficava: Cadê minhas ações em relação a isso? Porque a gente sabe que é uma área difícil. Que é difícil de ser abordado, as vezes traz frustrações, porque a gente precisa da vontade do usuário também de querer buscar saúde, buscar alguma ajuda, mas eu vi que eu preciso fazer um pouco mais (...)Mudou a forma de eu pensar (...) Eu cheguei a atender o paciente depois que eu fiz o SUPERA. Vem o paciente da minha área, inclusive, acompanhado pelo pai e ele veio falando... O pai, na verdade, preocupado porque o filho tava usando cocaína há uns cinco dias. Tinha usado umas cinco, seis vezes e ele, o filho, também tava preocupado porque não queria ser um viciado e veio procurar ajuda. E daí eu tive como dar uma abordagem diferente pra ele. Eu encaminhei ele pro CAPS. (E8)

Atendeu [as expectativas quanto à formação]. Não dá pra usar sempre, porque a teoria é bem intensa, mas dá pra gente ter uma ideia até mesmo para abordar. (...) Pra discussão do caso, dá até pra gente abranger a questão do uso abusivo, o que é uso abusivo, o que é, vamos supor, beber socialmente, o que já ultrapassou, tudo mais. (E10)

\subsubsection{Processo interrompido: Demandas relacionadas ao consumo de drogas que chegam na $A B$ e não são reinterpretadas como necessidades de saúde pelos trabalhadores}

Aos trabalhadores entrevistados foi solicitado que analisassem como as demandas relacionadas ao consumo de drogas chegam à UBS. Nesse sentido, percebe-se uma certa tipificação ou cristalização das demandas e da descrição das formas como estas chegam até o serviço. Não se percebe, nos discursos sobre o cotidiano de trabalho, processos de identificação de necessidades de saúde dessa população, ou seja, processos de reinterpretação de demandas. As demandas são tomadas e atendidas (ou não) da forma como são trazidas e expressas pelos usuários dos serviços e suas famílias, sem que sejam submetidas a 
interpretações, a partir do contexto de vida das pessoas que chegam na unidade trazendo tais demandas. Trata-se de um processo, podese dizer, quase linear. Se a demanda vem na forma de internação, ela é lida como internação.

Alguns sujeitos da pesquisa (E7 e E9) fazem a análise da frequência dessas demandas na $A B$, apontando que tal demanda na $A B$ não é significativa nesse nível de atenção.

Já foi mais [demanda de álcool e drogas]. Eu não sei exatamente porque, mas já foi muito maior. Especialmente no tempo em que eu trabalhava no hospital. No hospital tinha muito mais álcool do que droga mesmo. Droga maconha, cocaína/crack, quando eu trabalhava em hospital praticamente não existia. Crack já que é um negócio mais recente, existia no Rio de Janeiro. Não, não existia no Rio de Janeiro, agora que tá chegando no Rio de Janeiro. Mas o forte era álcool, em hospital psiquiátrico o forte era álcool... [Na UBS a demanda de drogas é] muito pequena, muito pequena. Álcool tem mais, benza Deus, mas droga tem, mas é muito pouco em relação ao número de atendimentos que a gente faz. (E9)

Diria que é uma demanda, é que é assim, que é frequente, diariamente, não, mas com uma certa constância. (E7)

Alguns trabalhadores (E2, E4, E5, E6, E10) relatam as dificuldades para que demandas desse tipo cheguem até os espaços da AB. Não há, por parte do serviço de saúde ou por parte dos trabalhadores, uma procura por tais demandas, apesar de ser uma questão reconhecidamente presente no território por parte dos trabalhadores. Nem mesmo estas demandas são reconhecidas ou ressignificadas como necessidades a partir de outras demandas que de fato chegam na UBS.

Tem alguns que eu sei que usam, mas não falam, porque assim, moram aqui há muito tempo, conhece bem, mas alguns vêm e falam. Ás vezes falam só pra você saber, nem querem ajuda (...) Então assim, mas procura geralmente 
eles não procuram. É muito raro. De dez se um procurar é muito. Às vezes você fica insistindo no assunto, não diretamente no assunto. (E2)

Nessa área que eu estou trabalhando, eu tô há sete meses. E em sete meses uma pessoa que veio aqui pedir ajuda diretamente relacionada ao consumo de drogas. Porque foi o que ele me relatou, que se ele não parar ele vai perder a família dele e ele não quer perder a família. Então, desse tanto que tem só uma pessoa veio me procurar em sete meses, bem complicado. (E2)

A gente sabe [que há o consumo de drogas] mas não pode falar nada porque se até o paciente não falar pra gente a gente não pode fazer nada. A gente pode tocar no assunto, tudo, mas não diretamente. Se a gente sabe que ali naquela casa tem um assim, mas não foi relatado pra você a gente tem que tomar muito cuidado pra eles não pensarem alguém falou alguma coisa assim. Fazer esse tipo de falação, né? (E2)

O paciente que é usuário de drogas não vem na UBS. Falar assim que eu quero... Além desse paciente que veio aquela vez. Agora ele vir aqui e falar eu sou usuário e quero parar não tem. (E4)

Atendo [demandas relacionadas ao consumo de drogas], mas como eu te disse, como é uma coisa muito mascarada, o paciente não fala pra gente, eu sei pela família, pelos vizinhos. (E5)

É o que a gente vê. A minha coletividade com eles [usuários de drogas] é profissionalmente, entendeu? Eu chego: 'E ai, parou de usar sua porcaria'. 'Não tia, mas eu vou parar'. No meu trabalho só tenho, que eu conheça, só tem três, três nada. Tem outra menina que eu tenho informação que toda vez que eu passo no quintal aquele cheiro exala, né? Só que ela não assume, ela nunca falou para mim. Eu sei que é porque eu passo lá e sinto o cheiro, (E6)

Às vezes é a mãe que fala, um tio, a vizinha. Que nem, essa moça que usa droga na casa dela, quem me contou foi a vizinha. Porque o marido dela usa [Risos]. O marido dela usa. Só que ela falou da vizinha que usa, não do marido, entendeu? Ela [vizinha] só falou assim: 'Nossa, esse pessoal fuma muita maconha, que o cheiro chega até aqui dentro de casa'. Eu escutei, entrou num ouvido e saiu pelo outro. Pronto. Daí eu fui fazer visita, né? Eu fui lá [minha vida é uma pá] e falei, 'O que você tem?', 'Eu não tenho nada, nada.' 
Heloisa da Veiga Coelho

Ai eu: 'Posso te perguntar uma coisa?' Ela: ‘Pode', 'Por acaso você é usuária de drogas?'. E ela olhou para mim, assim. E eu 'fica tranquila, sou profissional de saúde. Não é assim não'. Ai eu falei para ela, 'você tem, se você conversa com médico, se você conversa com advogado, ali fica. E comigo é a mesma coisa, eu não posso sair daqui e chegar numa casa de fulana e falar que você é dependente químico, que isso é problema seu, certo? Mas fala para mim, você usa? Ah! Eu uso. Você não quer se tratar?'. Ela falou assim para mim, 'não, ta bom assim'. Eu não tenho dificuldade de abordar, não tenho. (E6)

Chegam de diversas formas de chegar [as demandas]. Às vezes no começo, que precisa de ajuda no começo. Às vezes no fim, que perderam filhos, porque é usuário de drogas. Daí entra a questão social de resgatar esses filhos, aí não conseguem, aí pedem internação, então tem várias formas. (E10)

Quando os trabalhadores falam sobre as demandas que conseguem chegar ao serviço, eles qualificam tais demandas pelas maneiras como estas chegam. Nesta qualificação os trabalhadores apontam apenas os agravos que disparam a busca por ajuda por parte de alguns sujeitos (não associando as questões sociais imbricadas nesse processo). Também apontam quem são estes sujeitos que trazem ou facilitam o acesso desse tipo de demanda ao serviço. Também tentam caracterizar o fluxo destas demandas relacionadas ao consumo de drogas na UBS.

Alguns trabalhadores (E2, E5, E7, E10) apontam que a demanda vem através dos familiares. Outros (E4, E7, E10) apontam que são os ACS que trazem essas demandas.

Os processos que levam os sujeitos a buscarem ajuda, segundo relato dos trabalhadores, estão relacionados principalmente ao desespero de familiares e algumas vezes do próprio usuário em não saber lidar com a problemática do consumo de drogas nas suas vidas.

A maioria das vezes, geralmente, quem dá o primeiro passo é a família. (E2) 
Heloisa da Veiga Coelho

Certamente o familiar. Os familiares, né? [que trazem as demandas] Os pais, os avós. Avós que, assim, os pais de usuários que estão cuidando dos filhos desses usuários. Muitas, muitas. Pessoas que já são perdidas com esses problemas, já não sabem mais a quem recorrer. Às vezes até o paciente. Tem vários casos. (...) Alguns chegam desesperados, pedindo ajuda, pelo amor de Deus, já com sintomatologia, pra encaminhamento pro CAPS álcool e drogas. Outros comentam, mas não dão contam do que é conceito do uso de substância. Familiares também me procuram, pedindo ajuda. Tem um caso de um adolescente que eu tenho que ver, que é um adolescente de 15 anos, que eu não sei qual o estado dele, mas a mãe tá desesperada e na maioria das vezes eles querem internar. (E7)

Ele [usuário de drogas] era violento, tinha histórico de violência na família, e eles [familiares] vieram até a mim pedir ajuda. (E5)

Familiares e o usuário... Às vezes o próprio familiar procura o agente de saúde... Ajuda praquele filho, sobrinho, e às vezes o filho, sobrinho não está nem sabendo e às vezes nem tá no momento de ter essa decisão, e daí quer que o agente de saúde faça alguma coisa porque já está naquela situação que já tá vendendo coisas dentro de casa, já tá violento, agressivo, e tudo mais, e quer que mude a situação. (E10)

Quem traz a demanda é o ACS. O ACS vem e fala: Olha, tal usuário, assim, ele não tá conseguindo nem trabalhar, nem fazer o atendimento na UBS, tá tendo atrito com a família, o que vem também pra UBS são os parentes desses usuários, que vem procurar ajuda. Tá tendo muito roubo em casa, tá tendo muita briga, aí esses familiares vem procurar a gente também, mas é pouco. (E4)

A gente traz o caso e pensa. A gente fala. As meninas também falam: 'Olha eu fiquei sabendo que fulano usa droga pelo vizinho, não sei o que'. E ai, quando a gente fica sabendo a gente fica na nossa. Elas ficam na delas. (E6)

Então, as agentes, ás vezes, elas trazem o caso, quando a pessoa quer ajuda. Ás vezes elas trazem o caso sem a pessoa pedir ajuda, que elas percebem que a pessoa está no limite, a gente vai tentar intervir. (E7) 
Heloisa da Veiga Coelho

E o agente de saúde às vezes se sente na obrigação de ser o agente de mudança e traz o caso desesperado pra equipe. Daí a equipe traz o caso pro NASF e aí a gente abaixa um pouco a ansiedade. Olha, chegou ao limite, chegou ao seu limite, não dá, não é assim. É a questão de orientação que eu tava falando. De falar, olha, não é assim, né? Não dá pra você chegar na casa dele e tirar a força. E essa mãe, essa tia, não é assim que a gente vai ter que cuidar dela, né? E a questão da co-dependência e tudo mais a gente trabalha com isso também. (E10)

Apenas E9 e E7 apontam que os usuários de drogas também chegam à UBS pedindo ajuda. Por iniciativa própria, trazidos pelos familiares ou quando percebem que estão morrendo. (E7)

A minha experiência particular, a maior parte das vezes o usuário vem pra dar uma satisfação pra família, entendeu? A esposa, a namorada, a mãe, pra senhora, pra senhora, eu vou lá pra calar a boca desse povo. E esse paciente que chega assim, ele vem somente pra dar uma satisfação pra família.Tá vendo? Eu fui. Aí se a gente passar alguma medicação, alguma coisa ele vai dizer, não adiantou nada. Quer dizer, ele não está minimamente interessado em fazer um tratamento, isso aí é $100 \%$ de certeza de insucesso, né? A pessoa que vem pra fazer uma gracinha pra família, dar uma satisfação pra mãe ou pra namorada ou pra esposa, fatalmente não volta na segunda. Alguns poucos vêm, ele mesmo, por iniciativa pessoal e quase sempre, quase sempre, é paciente que já experimentou parar uma vez. Então vem aqui por motivo de uma recaída. Mas ele sabe que, esses que já tiveram experiência, que já fizeram algum tipo de tratamento, sabem que se ele receber algum tipo de suporte ele pode conseguir novamente ficar um tempo ou pra sempre abstêmio. Então é outro tipo de paciente que vem aqui, é esse que já teve uma experiência de tratamento, teve uma recaída, e por iniciativa pessoal ele termina voltando. (E9)

E1 relata que os usuários de drogas que chegam ao seu consultório são aqueles que estão começando a experimentar. Este fato tem relação com o público que este trabalhador atende (jovens) e com o tipo de trabalho que desenvolve, pois, como vimos anteriormente, as demandas relacionadas ao consumo de drogas 
que chegam à UBS são aquelas em que usuários e familiares já estão bastante comprometidos com o uso abusivo e danoso de drogas.

Agora, quem chega mais aqui é aquele usuário que está começando, que está experimentando. Ás vezes já teve um uso pesado e agora está usando menos. Eu acredito assim, por exemplo, ás vezes até chega aquele usuário pesado e que ele vem no desespero. Ele vem uma vez e depois é muito difícil você resgatar. Mesmo sendo, por exemplo, do PSF, a gente fala assim pra agente: Olha, fulano de tal não veio mais, vê se ele vem, mas é difícil a gente conseguir. Agora, o que a gente tem conseguido é aqueles que estão começando. É aqueles que estão experimentando, esses vêm e esses têm participando muito dos grupos (...) Uma minoria vem porque fala: Eu estou usando e tô querendo. Ou então vem junto com a mãe. Olha, esses são os que mais fogem, né? Quando vem junto com a mãe. Porque não é a procura dele, não é a questão dele. Ele vem e sofre também. É mais difícil de você resgatar. Talvez também por que esses também já estão usando há mais tempo, né? Então, mas chega... (E1)

Os sujeitos E2 e E5 referem que as demandas relacionadas ao consumo de drogas não chegam de forma direta. Os usuários de drogas chegam até o serviço trazendo outras demandas/queixa. As colocações destes trabalhadores apontam que há uma ressignificação das demandas trazidas pelos usuários de drogas por parte de alguns profissionais de saúde. Porém, o reconhecimento das necessidades por trás dessas demandas não é concluído, pois, para que isso aconteça é necessário que este profissional de saúde acesse recursos (meios e instrumentos do processo de trabalho) que não Ihe são oferecidos em sua formação. Também as formas de organização dos processos de trabalho na $A B$ não contribuem para esse movimento de identificação e reconhecimento das necessidades de saúde da população atendida na $A B$.

Mas na época ele veio, pediu ajuda pra mim falando de dentista. Ele não veio diretamente com relação ao consumo, mas como uma coisa leva a outra... Se 
Heloisa da Veiga Coelho

você atender aí e tentar vincular uma outra coisa eles acabam aceitando. (...) Às vezes você fica insistindo no assunto, não diretamente no assunto.(E2)

Não. Não chegam [demandas relacionadas ao consumo de drogas]. Talvez chegam por outro motivo. Uma queixa clínica, mas não diretamente ligada ao consumo da droga, entendeu? Na minha área não aconteceu isso ainda, de eles virem aqui por outro motivo, sabe? (...) Tô sem remédio. Falam bobagem.Que tão bem. Aí eu tento puxar mais o assunto, entrar mais. Nossa, é como se fosse uma redoma, uma redoma de vidro, sabe? Eles não permitem que você chegue até eles. (E5)

Apenas um sujeito da pesquisa (E2) aponta que as demandas por vezes são trazidas de forma ampliada, já como necessidade de saúde. Mas o trabalhador, ao se deparar com uma necessidade de saúde, não consegue encontrar uma intervenção adequada para tal necessidade no elenco de práticas (muitas vezes reduzidas) que possui. O único recurso do trabalhador é reduzir tal necessidade às práticas disponíveis, enquadrando-a no modelo de atenção.

Geralmente eles [usuários, familiares] pensam assim, que qualquer problema que você tem que não é de saúde, pra eles usar droga não está prejudicando a saúde deles, tá prejudicando a convivência com a comunidade. Então eles vão vir atrás do assistente social pra ver que resposta o assistente social vai dar. Porque geralmente eles vêm procurar porque está afetando. Eles não tão trabalhando, não tem o que comer. Então, muita gente diz que que adianta um tratamento pra drogas se eu não vou ter comida em casa? Às vezes não tem condições de moradia, então é assim bem complicado. (E2)

A análise acima mostra a limitação dos serviços de saúde da $A B$ em trabalhar de fato com as necessidades de saúde da população que vive no território de abrangência da UBS. Esta dificuldade é resultado principalmente das formas como se organizam os processos de trabalho nestes espaços de produção de saúde. 
Os entrevistados (E3, E4, E8, E10) apontam ainda que a demanda relacionada ao consumo de drogas que mais chega à UBS é por internação. Os usuários a trazem por considerarem a internação uma demanda "solucionável" para o sistema de saúde. Tal demanda é consagrada no senso comum como a "única saída" para o problema do consumo problemático de drogas e esta ideia é reforçada pela mídia, pelas instituições formadoras dos profissionais de saúde e também pelas formas de produção dos serviços de saúde, que não ampliam as demandas, entendendo-as como necessidades de saúde.

Foi uma das primeiras aproximações que eu fiz, inclusive em termos de rede, como é que funcionava essa questão da internação. A gente sabe que no município a gente tem como recurso de internação entidades filantrópicas, muitas vezes sem nenhum tipo de tratamento clínico associado, uma coisa de auto-ajuda mesmo (...) Eles falaram exatamente o fluxo que a gente sabe. Primeiro um encaminhamento para uma unidade de saúde, que você tem. Já foi pra um CAPS? Já tentou o tratamento ambulatorial? Quer dizer, já foi identificado que é um caso de internação, e aí entra essa questão, né? Quem identifica? Porque a fala do paciente e da família do paciente é: Eu identifiquei o problema que é de internação. E não tem na rede, né (internação)? Então assim, a primeira coisa é que você vai dar uma resposta no primeiro momento. Pode até ser que às vezes tem casos que podem ser de internação, que é necessário uma internação, mas você não tem aquela resposta na hora. $\mathrm{Na}$ verdade, o que tem, ele quer que você faça o trâmite. (E3)

Por favor, preciso de uma internação porque ele ainda vai acabar se matando.(...) A angústia é tanta da parte de internação que a gente não vê, não tem noção do que a gente quer, assim. A família quer, tipo assim, tirar aquele problema da nossa frente, porque assim, em conversa não adianta, né? Só você conversar, conversar, porque ele não te ouve mais. E aí a gente precisa buscar ajuda. Só aquelas conversas que você passa em entrevista com profissional da saúde, e eu sou profissional da saúde, eu já tentei fazia mais de ano. (E4) 
Heloisa da Veiga Coelho

Têm duas usuárias na minha área, usuárias pesadas mesmo, uso abusivo, que elas já vieram. Uma delas já veio várias vezes aqui comigo pedindo internação. Eu quero internação, porque eu preciso ser internada. A gente conversou com a assistente social, viu o que a gente podia fazer, encaminhamos pro CAPS e ela sempre acaba do mesmo jeito, na casa dela, depois de um tempo vindo pra cá pedindo internação. E eu nunca consegui ver uma internação dela. Ela já foi encaminhada pra CAPS e ela não consegue acompanhar. Já foi umas duas, três vezes pro CAPS e eu nunca... e fica sempre assim naquela mesma coisa... e vai e volta e vai e volta e não vejo melhora do caso dela. Talvez ela fosse uma boa paciente para redução de danos. (E8)

A maioria é internar. Quer a ajuda do agente pra internação. Na verdade eles querem tirar o problema de dentro de casa. A maioria é internação, e aí quando a gente propõe CAPS, ah eu já fui lá e não deu certo, porque o dar certo pra eles é tirar de casa e internar. (E10)

Não é sempre [que o tema de consumo de drogas é abordado na terapia comunitária]. Mas já teve caso de uma das mães que o filho era usuário de drogas. Ela tinha muita dificuldade, muita ansiedade e ela não conseguia mais lidar com o problema. Ela solicitou internação, não tinha muita solução. (E4)

É grande o número de pessoas que procuram o serviço social pra tentar internação para algum familiar ou até psicótico quando o paciente vem passar agora eu preciso desse acordo. (...) Tem situações em que eles vêm com a expectativa de que você é a última alternativa, né? Mas a alternativa para uma resposta que ele já se deu. Ele parte do seguinte: Eu quero internar. Eu quero tirar esse problema da minha frente bem rápido. Eu não tenho, eu não consigo lidar com isso, não tenho como resolver, então eu quero um lugar para internar meu filho, ou o meu marido, ou a minha mãe (...) como as pessoas chegam ao limite assim do esgotamento e da necessidade de uma resposta imediata. (E3)

A forma como a rede de Saúde Mental foi se configurando no país, através da Reforma Psiquiátrica, aposta em serviços extrahospitalares para atendimento das demandas, incluindo as relacionadas ao consumo de drogas. Isso gera um descompasso entre a demanda por internação, que é a demanda prevalente nos 
serviços de saúde de forma geral, e a oferta de serviços de saúde. Esse descompasso é causado principalmente por não haver uma transformação dessas demandas (aquilo que é sentido pelos sujeitos e que é concreto em suas vidas) em necessidades de saúde a partir de uma análise ampliada dos elementos que estão imbricados no fenômeno como as formas de viver e trabalhar das pessoas que vivem no território. Esse descompasso é apresentado nos discursos dos entrevistados (E1, E3, E4, E7, E9).

Eu pelo menos penso que o trabalho da unidade de saúde prioritariamente é um trabalho de acompanhamento, de atenção á saúde primária, é um trabalho de todo dia, preventivo. É claro, isso no ideal, né? Para que você pudesse ter uma saúde em que você tivesse uma prevenção, hoje muitos casos chegam na UBS críticos, já em um estágio avançado de diabetes, hipertensão. E também saúde mental e de uso de outras drogas. (E3)

Por exemplo, veio um paciente aqui, na unidade, pra passar em consulta que ele queria de todo jeito que a gente conseguisse internação naquele momento. Só que é assim, nós da unidade, o que a gente poderia fazer? A gente ia pegar, levar ele pra... quando tá em crise, levar lá pro hospital Sabóia. Chamar a ambulância para levar ele pra lá. Mas ele não queria. Ele se revoltou quando a assim gente falou: Não. A gente vai levar o senhor pro PS porque o senhor tá alterado. Vai ter o atendimento da psiquiatria. Mas não é isso. Você não tá entendendo. Eu quero uma internação. Mas senhor, nós não podemos conseguir uma internação nesse momento. A gente vai ter que fazer um atendimento ambulatorial. Se realmente é internação que o senhor que mesmo. Mas não, não tem conversa. Aí começou a falar alto, começou a querer, quase agrediu o dr...[psiquiatra]. Começou a agredir o guarda. Aí a gente teve que chamar a polícia. (E4)

Não, você tem que trazer ele aqui, pra fazer um acompanhamento, porque se a gente não tem assim, uma solução, um bom desenvolvimento no acompanhamento ambulatorial, aí a gente interna. (E4) 
Heloisa da Veiga Coelho

Agora quando é um caso assim que já tá muito sério, que já perdeu todos os vínculos, que está... esse paciente a gente tem que encaminhar então pro CAPS, ou falar com o Henrique, que é o psiquiatra. (E1)

Em todos os casos, eles acham que internação vai resolver o problema e a gente tenta fazer a pessoa pensar que ela tem que mudar os hábitos dela dentro do ambiente que ela vive. (E7)

A gente manda pro pronto socorro (casos de intoxicação) Ele vai ser atendido como doente psiquiátrico, surtando assim grave, alucinando, tendo delírios. (E7)

Aí a gente encaminha pra... dependendo do caso, dependendo da gravidade, a gente manda ou direto pro hospital geral que tem suporte psiquiátrico, né? Aqui tem o hospital Jabaquara, o hospital da gente referência é o Jabaquara. Quantos hospitais agora estão com esse requinte de psiquiatria funcionando? Naquele que eu sei [Jabaquara] funciona com diarista e com plantonista. E tem um mínimo de enfermaria, um mínimo de leito e depois encaminha ou pra CAPS, se for o caso, ou pra internação mesmo, fechada tipo Água Funda. CAISM Água Funda. (E9)

\subsection{AS PRÁTICAS PELO OLHAR DO TRABALHADOR: PRÁTICAS PROTOCOLARES $X$ PRÁTICAS QUE AMPLIAM O OBJETO DA ATENÇÃO À SAÚDE}

A partir dos discursos dos entrevistados (E2, E4, E5, E8) nota-se a insuficiência dos meios e instrumentos de trabalho para lidar com questões tão complexas que estão imbricadas no fenômeno do consumo de drogas. Assim, estes trabalhadores não conseguem recortar o objeto do seu processo de trabalho de forma ampliada, reinterpretando as demandas que chegam e transformando-as em necessidades de saúde. Isso gera práticas restritas, que seguem protocolos e programas pré-estabelecidos, com impacto bastante restrito na vida das pessoas que procuram os serviços de saúde em busca de ajuda/cuidado para seu problema. 
Heloisa da Veiga Coelho

Assim, toda a casa que geralmente que vai, eu me apresento. Quando começo eu sempre que passo falo que se precisar de ajuda a gente está à disposição, que eu posso tá ajudando. (...) Eu acho que eu sou muito cara de pau. (...) Eu acho que a gente que tá lidando diretamente com pessoa, lidando com a saúde, você não pode ter essa vergonha de falar de nada. Porque se a pessoa perceber que você tá tendo eles não vão querer falar. Então é um assunto que eu tenho que estar ali de cabeça aberta pra estar conversando, então pra mim é tranquilo. Eu não vejo problema em perguntar.(E2)

A gente vem e relata [demanda sobre consumo de drogas] na reunião,né? $E$ daí a gente procura... se a pessoa vem até a unidade... é que é assim, é passado por uma consulta ou com a médica ou com a enfermeira pra tá relatando o problema. Aí assim, a gente passa o caso pro NASF pra ver uma data pro paciente estar passando com uma psiquiatra... Então se a gente vê que o paciente é muito urgente, não vai ter tempo, então a gente tem que encaminhar pro CAPS. Mas geralmente eles não vão não. (E2)

Eu li nesse manual. Tem a política, todo o fluxo de atenção. Tem que dar entrada geralmente na UBS, a gente encaminha pro CAPS, do CAPS tem outros atendimentos de multi profissional, aí a gente tem todo o vinculo CAPS e UBS. (E4)

Teve uma das pacientes, usuária, que ela veio com uma demanda da ACS. A ACS veio, discutiu o caso. Aí a paciente veio pedir informação pra gente da filha que tinha ido pro hospital e precisava de uma medicação que eles não tavam autorizando. Como eu já sabia do caso eu falei: Vem cá, tenho que conversar com você. Aí eu já puxei o assunto, e ela contou tudo pra mim e nisso eu já conversei com a... [médica da equipe] e aí eu e a... [médica da equipe] já conversamos juntas com o paciente e a gente já começou o atendimento. (E4)

Às vezes a gente fala: Ah, vamos fazer um grupo. Só que o pessoal não vai. Aí eu falo assim: Ah, eu vou falar sobre drogas. Muitas vezes a demanda não vem até nós. Não querem a presença, talvez o que seja importante é a gente fazer com os adolescentes pra que não iniciem. (E4) 
Heloisa da Veiga Coelho

Para todos [questionamento sobre consumo de drogas], porque a gente faz histórico, antecedentes familiares, antecedentes sexuais, fumo, alcoolismo, é rotina perguntar sobre isso. (E4)

Manda pro CAPS ad, né? Encaminha, nunca deixa sem resposta nenhuma. (E5)

Pergunto [sobre a questão do consumo de drogas na rotina de atendimento]. Assim, alguns a gente acaba esquecendo, tem tanta coisa pra perguntar. (E8)

Quando chega um paciente pra gente, pedindo ajuda, a gente primeiro tenta passar em consulta médica, de enfermagem, a gente faz uma VD. Em outros casos a gente passa pra equipe do NASF, que tem psiquiatra, psicólogo, tem terapeuta ocupacional, tem outros profissionais da equipe multi profissional e dependendo a gente conversa se é caso pro NASF. Em algumas vezes o NASF assume junto com a gente todo o tratamento. Não encaminha nada. $E$ já teve ocasiões da gente encaminhar pro CAPS e como o paciente mora na nossa área também acompanhar com a gente. A gente tenta sempre resgatar, resgata pra gente, eu sempre vou em VD, questiono se tá indo, se não tá indo [no CAPS], porque não tá indo, ás vezes o paciente não é sempre que encontra porque o horário de CAPS é o horário da unidade. Mas a gente pede pro ACS comunicar pro paciente estar passando com a gente. A gente tenta manter o contato com esses usuários sim. Acho que todos que eu encaminhei eu me recordo acho de uns dois, três só continuaram no CAPS. Os outros eram talvez casos mais graves, que vieram até mim. (E8)

As principais práticas direcionadas aos usuários de drogas na $A B$, levantadas pelos entrevistados (E1, E4, E5, E6, E7, E8, E10), restringem a atenção ao usuário de drogas a consultas individuais, visitas domiciliares e encaminhamentos para outros níveis de atenção ou para outros trabalhadores especializados. O objeto do processo de trabalho são os agravos (qualificados como demandas) que conseguem chegar até os serviços. Tais práticas seguem estritamente o que é preconizado nos manuais e fluxogramas estipulados a partir das políticas públicas que versam sobre o tema e não são configuradas a partir das necessidades de saúde da 
população que vive no território. Por isso denominamos tais práticas como protocolares.

Eu acho que não tem nenhum tipo de discussão... Por exemplo, quando as equipes descobrem algum caso elas ficam... elas encaminham o adolescente pra mim... pra eu atender.- Tô com um caso de um adolescente assim. Não dá pra senhora atender? E aí elas encaminham. Então, as equipes encaminham. (E1)

Então, porque é assim, quando a pessoa é usuário de droga e ele quer parar a gente dá assistência, tipo assim, a médica, na sequência o clínico, tem eu como enfermeira, e geralmente a gente passa pro NASF também. (E4)

Eu geralmente faço a entrevista e aí depois eu vejo assim quais as perspectivas de vida da pessoa, o que levou ao uso e tornar-se usuário de drogas. Porque a gente tem uma ficha chamada matriciamento da saúde mental e dentro desse matriciamento da saúde mental a gente tenta colocar o usuário de drogas, aí também. E fora que também eu participo na terapia comunitária. (...) Aí o NASF tem aí. Tem a parte do psicólogo, da assistência social e então a gente começa a envolver todo mundo... Pro NASF não [ter facilidade de agendamento], porque a gente tem que ter uma discussão do caso. Com a... [médica da equipe], a... [médica da equipe] abre uma vaga pra ser atendido o mais breve possível, muitas vezes não consegue pro dia seguinte, mas assim, na semana a gente já consegue marcar. (E4)

...eles queriam saber se tinha como um psiquiatra atender ele, a princípio foi o Dr... [psiquiatra] que ele me falou, aí eu passei pro NASF, aí a Dra... [médica da equipe], que estava na época, falou assim: Não, então adia o NASF. Ele precisava de receita, de carbamazepina, eu acho, né? Aí ele tava sem receita também e a Dra... [médica da equipe] falou assim: Não, eu vou fazer uma VD lá pra ver como que é a dinâmica familiar, como que funciona tudo, né? $E$ depois a gente fala com o NASF direitinho. Inclusive o NASF foi lá depois comigo também, viu. Mas aí já não precisava mais e logo ele teve essa internação. (E5)

Inclusive eu tenho que toda semana, a gente tem que ficar indo lá, pra mim ter acesso. Porque ele pega a rispiridona aqui, né? E faz todo o processo de alto 
Heloisa da Veiga Coelho

custo, né? Então tem que ficar vendo sempre, pra ver se está tudo sob controle, se tá tudo certinho. Semana que vem eu passo lá na casa dele, mas ele tá bem, ele não tá bebendo mais, ele tá se segurando, pelo menos a família tem me referido isso. (E5)

Na favela Alba, onde eu trabalhava, tinha um beco que se chamava "Cracolândia". Então, era o beco que só tinha aquelas pessoas que usava drogas. Entendeu? E eu entrava nesse beco e esse beco era na minha microárea e eu fazia visita em todo mundo. Todo mundo me respeitava. Quando eu chegava que eles estavam fumando, eles escondiam. Eles escondiam de mim. (E6)

Eu tive um que até tentou, inclusive a... [trabalhadora do CAPSad], agora eu to lembrada, lá do CAPS ad, ela recebeu ele lá. Essa que vem aqui às terçasfeiras. Mas aí ele não voltou mais. Vira e mexe eu encontro ele. A gente já voltou na casa dele pra ver o que tinha acontecido. $O$ outro que procurava ajuda quando tinha momentos de... aquele que eu te falei que caiu, que tava voltando pra casa. Este tinha uns momentos de desespero, ele chorava, pedia ajuda... Não [vai ao CAPS ad]. O máximo que eu consegui era que ele passasse com o Dr... [psiquiatra], o psiquiatra, e aí ele não suportou esperar uma hora. (E7)

Eu não entrei no mérito [questionamento sobre consumo de drogas na consulta de uma paciente]. Eu perguntei se ela bebia, se ela fazia alguma coisa, o quê que tava acontecendo de errado, se ela usava alguma coisa... Não tenho dificuldade, mas eu senti que ela não queria falar. Eu pergunto: $E$ aí você tá usando droga? Usa cocaína, crack? O quê que você usa? Até pra saber o quê que é, porque eu não tenho esse problema. Mas ela não queria contar. E aí, assim, eu não insisti porque acaba perdendo com o tempo. De certa forma ela não contou essas coisas. (E7)

Não, ele passa só lá [no CAPS]. A orientação, a nossa referência pra esse tipo de problema é o CAPS ad, a gente tem dois CAPS. (E7)

É, uma coisa importante que a gente faz é VD e consulta mesmo, abordagem individual. (E8) 
Heloisa da Veiga Coelho

O sofrimento aparece [na terapia comunitária] pelo não saber o que fazer. Como é que eu faço? Eu não aguento mais. Só que tem pessoas que já venceram isso. Que o marido já parou, já passaram por isso. Há relatos de pessoas que já venceram, então fortalece essas pessoas, que elas sentem. (E10)

...essa questão da abstinência, dá pra lidar com a redução de danos e é isso que eu prezo também quando falo com o usuário. É esquisito isso na $A B$, perceber isso. (E10)

Alguns sujeitos da pesquisa (E8, E9, E10) na apresentação das práticas direcionadas aos usuários de drogas apontam que, mesmo as práticas de trabalhadores especializados, não ampliam o objeto dos processos de trabalho, que continua sendo o indivíduo "incapaz", "fraco" ou "doente". Também estes trabalhadores não possuem recursos suficientes para ampliar o objeto e transformar as demandas trazidas pelos usuários de drogas e suas famílias em necessidades de saúde.

Ela [equipe] vai atender ele, aí vai passar pro psiquiatra, no caso pro Dr... [psiquiatra]. O Dr... [psiquiatra] foi e deu um calmante pra ele. Mas aí deu esse calmante. Pronto. E acabou ali. O que aconteceu? O paciente tomou uma cartela de diazepan, porque ele deixou bem claro pra mim: Eu queria morrer, mas não morri. Tô aqui. Aí o paciente vai ficar grogue. É, e ele não vai tentar fazer de novo? Da próxima vez que não vai ter diazepan, ele vai descer pra boca, vai tomar junto com qualquer coisa... (E2)

(...) Ou eles [NASF] marcam uma VD pra ir até a casa do usuário, psiquiatra, psicólogo, fono, quem eles acharem que é melhor. Ou faz uma VD, ou agenda uma consulta pra esse usuário, pra essa pessoa. O paciente vir até aqui então... Tem caso em que eles [NASF] assumem. Vamos tomar medicação, vamos marcar com a psicóloga, vamos encaminhar para algum um grupo, ou encaminhar para o grupo de terapia comunitária, ou para o grupo de saúde mental, ou para o grupo de atividade manuais. (E8) 
Heloisa da Veiga Coelho

Em relação aos usuários não tive nenhum caso assim resolutivo que me deu algum retorno positivo [com relação à atuação do NASF]. Com relação ao usuário de droga não. Em alguns outros casos sim. Resolutivo em alguns outros casos. Mas de usuário de droga não tive nenhum caso positivo. (E8)

Eu acho que sim, acho que a gente tem tido sucesso. A gente, como eu falei, não é um negócio científico, porque desaparece, tipo assim, ele vem melhorando, depois fala: Ah doutor, eu tô bem e tal. Daí depois de três meses ele ter voltado, não dá pra eu saber. Não é um negócio que eu tenha o retorno dessa informação, mas eu acho que realmente, porque a gente percebe que ele vem procurando um apoio, ele melhorou a ansiedade, aquela fissura e tal, e depois disso não vai vir mais, não é um abandono, é ele se dar alta, mais ou menos assim. Não sou eu que dou alta, invariavelmente eles se dão alta. Que a gente tem receio, na verdade, a gente eu tô dizendo eu, de dizer: Não. Você pode ir embora, você fica querendo que o paciente esteja por perto, pra gente ter mais ou menos noção de como é que anda. (E9)

Então tem nove profissionais [NASF], cada um com a sua especificidade. E é nessa especificidade que a gente atua com uma equipe multidisciplinar. Cada um com um olhar. $E$ esse olhar a gente trabalha na equipe (...) Minha experiência no NASF é mais no matriciamento junto às equipes de saúde da família. Então esse matriciamento acontece nas reuniões de equipe onde os casos vêm pra gente. A discussão do caso vem na reunião e onde acontece $o$ matriciamento e desse matriciamento acontece o atendimento ou visita domiciliar, atendimento. (...)Há o matriciamento na discussão do caso. Após a discussão do caso há a marcação da consulta, agendamento, o atendimento compartilhado com a médica ou enfermeira da equipe, pra nesse atendimento a psiquiatra, a psicóloga e a TO do NASF atendem junto com a enfermeira ou a médica da equipe e vai acompanhando. E o acompanhamento desse paciente é feito agora, depois desse primeiro atendimento, pela equipe. Daí é a equipe que toma as rédeas desse caso. Daí se precisar de mais algum apoio, solicita apoio do NASF de novo... O atendimento específico pode acontecer com a psicóloga também, mas $o$ atendimento com a psiquiatra, faz o primeiro atendimento, o acompanhamento é feito depois com a médica da equipe que vai assumir o caso e o NASF vai continuar acompanhando, porém a médica da equipe toma pé do caso também e vai acompanhar. Há também o encaminhamento. Além desse atendimento há o encaminhamento, né? Que daí no CAPS eles já tem todo um trabalho completo, lá tem as oficinas e tudo 
mais. O atendimento e o acompanhamento [da equipe do NASF] ás vezes é mensal, porque não dá para ter um acompanhamento semanal. Eentão tem uma agenda. O NASF não é porta de entrada, é apoio as equipes. Então nesse caso [necessidade de acompanhamento psicoterápico contínuo], teria algum outro atendimento pela equipe e um encaminhamento que poderia ter psicoterapia e daí tem a rede. Tem o profissional na psicoterapia. Pra algumas outras UBS [encaminhamento] que tem a psicoterapia. Tem o Melonni, Mazonni.

Apenas E1 consegue ampliar o objeto de suas práticas a partir de uma compreensão crítica do processo de produção dos serviços de saúde e conhecimento das necessidades desses sujeitos. Estas práticas, entretanto, são restritas e não conseguem se expandir por conta das formas como se organizam os processos de trabalho no serviço de saúde.

A gente tem trabalhado muito assim junto com eles [jovens]. A gente não tem trabalhado a história assim com a relação com as drogas. Mas deles virem... deles se socializarem dentro do posto... deles começarem melhorar o auto cuidado, de colher os exames e aí gente faz assim... estar encaminhando pra cursos, pra escola de novo, e eles... sinto aqui nesses grupos que a gente tem conseguido trabalhar nesse sentido. (...) Se o adolescente vem com a mãe, eu converso com os dois juntos, converso com a mãe separado, para saber como que é a dinâmica dessa família, converso com o adolescente, convido para ele participar das nossas atividades, vou fazendo uma coisa assim né... de ir indo por outros lados, olha você tá com acne. Vamos tratar a pele? Vamos pedir uns exames? Vamos ver seu peso? Sem focar muito, exatamente assim, a questão droga. (E1)

Eu até lembro da fala de um deles que usava muita maconha. E aí eu brinquei e falei assim: - Olha, porque você usa? Porque me dá felicidade, doutora. Daí eu falei assim: - E se a gente pusesse uma outra coisa que te desse felicidade? - Um trampo doutora, um trampo... (...) Então, eu acho que o que a gente tem trabalhado junto com os adolescentes, tendo esse espaço deles estarem dentro da unidade, de reconhecê-los como pessoa, eles se sentirem aceitos dentro da unidade. Acho que a gente já começou esse trabalho. Agora, eu acho que faltam outras questões,né? (E1) 
Heloisa da Veiga Coelho

Porque se eu tô tirando a droga, se eu to falando pra ele... se eu to desconstruindo que isso traz a felicidade, o que eu vou por nesse lugar? Então a gente tem feito alguns vínculos com ONGs que tem cursos técnicos, nós levamos eles lá para conhecer o local, leva dez, dois vão fazer. Mas acho que nesse sentido... acho que a ideia é assim, desconstruir... a droga traz felicidade pra você, momentamente, mas traz. Então, mas te traz muitas infelicidades depois. Então, o que a gente pode por nesse lugar, o que tá te faltando, igual aquele menino falou é trampo doutora, eu quero um trampo,né? Então, assim, talvez se você conseguir buscar outras coisas, eles conseguem substituir,né? Porque eu tenho impressão que se eu conseguir trabalhar as outras questões vai melhorando essa questão [do consumo de drogas]. (E1)

E uma vez por mês a gente fazia o grupo com as mães. As mães precisam muito disso. A gente percebe que as mães também estão carentes. Elas precisam ter esse espaço de ser escutadas. (E1)

Você lembra que a gente pedia pra [ACS] fazerem um relatório das visitas e quantas vezes o relatório saia escrito: Tudo bem, tudo bem, tudo bem. E quando nós íamos fazer visita chegava lá e a pessoa aí, a pessoa toda descabelada, a casa toda suja, as crianças fora da escola, como é que podia estar tudo bem? O que que é tudo bem? Entendeu? Então, acho que entra dentro disso. O que que era tudo bem? Então acho que isso não é só no caso dos usuários de drogas. Mas é uma coisa assim,que... Como que você se envolve? O que que é tudo bem? Então não tá com pressão alta, não tá com diabetes, é isso? Eles [ACS] estão executando corretamente o que é cobrado deles. Dengue, é a dengue... (E1)

Alguns trabalhadores (E1, E3, E4, E6, E7) apontam dificuldades de produzirem práticas que ampliem o objeto dos processos de trabalho, pois estes processos estão sujeitos à normatização dos protocolos e programas estabelecidos pelas políticas de saúde, construídas em nível central sem a participação de trabalhadores e população residente nos territórios atendidos. O processo de produção dos serviços de saúde na atualidade também impacta negativamente na construção de práticas mais ampliadas. 
Heloisa da Veiga Coelho

Por exemplo, no começo desse ano mesmo, antes de começar o ano, nós tínhamos a proposta [de planejamento] pra esse ano de atendimento. Nós convidamos várias enfermeiras da unidade, do PSF, pra participar desse planejamento. (...) O planejamento de atendimento de adolescente. Não especificamente o caso de drogas, mas que eu acho que pode ser tratado junto (...) Então, nessa reunião acho que só duas enfermeiras conseguiram ir no dia da reunião. Dessas duas, uma ficou um pouquinho mais. Dependendo então de toda a demanda, da produtividade que elas são cobradas, isso [demanda do consumo de drogas] não é uma coisa importante dentro do PSF... então elas tem que dar resposta a produtividade, ao atendimento, ao atendimento... Então nenhuma participou. Uma delas ainda assim, trabalha um pouco mais junto com a gente tal, mas muito pontual... foi passado, mas a gente não conseguiu... então por exemplo, esse banco de dados,né? Nós fizemos uma reunião, porque nós estávamos querendo a casa do adolescente, então nós fizemos uma reunião aqui no posto em que nós chamamos diretoras das escolas, das creches, pra passar os dados. Foi pouquíssimas, foi muito pouco, dá para contar em uma mão quantos funcionários [da UBS] foram assistir. Aqui dentro, que eles sabiam que era o banco de dados dos atendimentos que nós fazíamos aqui. (E1)

Se eu te falar, você vai me trazer uma resposta satisfatória? Você vai resolver meu problema? Porque pra mim essa é a palavra chave, você vai resolver meu problema? Não vai, né? Então? Então é melhor não vir. Então não mexe. E daí elas [ACS] ficam divididas. Entre a cruz e a espada. Porque elas sabem que poderia se fazer um monte de ações que não são feitas. Ações individuais, coletivas, institucionais, interinstitucionais. E saúde vai até certo ponto. Depois o que se faz mais pra frente, e daí? Você se depara com a barreira. (E3)

... a demanda que a gente tem de fazer várias coisas ao mesmo tempo, a gente acaba deixando algumas um pouquinho pro segundo plano (...) É muito pouco (atividades coletivas direcionadas ás questões mais amplas da saúde). Se a gente falar: Olha, tem todo mês? Isso não tem não. Tem muitos grupos que a gente dá mais prioridade, tipo o grupo de hipertenso, de gestante. Você tem também o dependente. A rotina vai te consumindo e ás vezes as drogas vai ficando em segundo plano porque a gente tem dificuldade de lidar, então pode ser isso porque a gente vai deixando em segundo plano, que é um tema importante. (E4) 
Heloisa da Veiga Coelho

Quando você trabalha em favela tem uma cultura. E eu vim pra outra totalmente diferente... O trabalho de lá é diferente, porque muita gente não trabalha. Você encontra mais as pessoas e as pessoas é mais participativo nos grupos. Os grupos de diabetes, hipertenso, adolescente, gestante. Lá, eles são mais participativos. Aqui eles participam menos. A gente vai chamar. Ás vezes vai nas casas e vem poucas pessoas, entendeu? A diferença de você ter uma coletividade dos moradores da favela é diferente da nossa coletividade daqui. Porque eu, como agente de saúde, quando tem algum grupo eu tenho que ir na casa para buscar (...) Eu acho que é falta de incentivo [baixa participação em grupos educativos na UBS]. Falta de incentivo, talvez do ACS ou da família da pessoa. Porque eu acho assim, como eu trabalhava muito com grupo lá na UBS (favela Alba), aqui tem grupo, mas não é tanto que nem lá. Porque lá tinha espaço para fazer grupo, aqui não tem espaço para fazer grupo nessa unidade. Essa é a verdade, entendeu? Porque aqui tem uma quadra que a gente faz um grupo de verificação de PA e caminhada. Mas assim para você fazer um grupo fechado na comunidade já não tem. Tá aí o problema. (E6)

Então, teve o último caso recente agora que eu fui visitar. A avó que disse que [a neta]) era usuária de álcool e drogas. As agentes sabem e ela tinha duas crianças, ela mora num cortiço. A mãe mora no quarto de baixo e ela mora no quarto-cozinha em cima. É o extremo do lixo, sabe? Roupa, prato, comida, chão, um cheiro de sujeira. la também, duas crianças, uma menina de cinco anos, e um bebezinho de um ano e meio, dois. Só as crianças não eram largadas porque a vó cuida e ela está tentando tirar essas crianças legalmente. Aí a gente discutiu com ela [usuária]. Perguntei o que tava acontecendo, porque ela tava daquele jeito. Ela não abriu que era usuária de drogas, mas ela disse que ela perdeu a vontade de viver, que ela não queria saber de nada, só ficar em casa. Aí assim, o vínculo com ela, até por conta do pré-natal e das consultas e aí eu comecei: Nossa, eu to assustada de ver como você tá afundando. Olha pra você, você é jovem e tal, tem 24 anos, será que você não precisa de ajuda, será que você não quer ajuda, você vai continuar vivendo assim até quando? Você já parou pra refletir? Olha seus filhos. Só você tendo essa conversa não leva a nada, você precisa de um apoio, fala com sua médica, conversa com ela. Agora a mãe diz que ela fica usando a desculpa de que é doente. Ai. Tô com depressão, que eu sou 
Heloisa da Veiga Coelho

doente. Nossa e eu vim te ajudar pra que? Será que a gente não conseguiu? Ela voltou. E a irmã dela também é usuária de drogas. (E7)

Quando os trabalhadores (E2, E4, E6, E7, E8, E9, E10) apresentam propostas de práticas direcionadas aos usuários, estas são limitadas justamente por não se configurarem a partir das necessidades de saúde dos sujeitos e não ampliarem o objeto destas práticas. São propostas que não têm potencial de concretização, dado as formas de organização dos processos de trabalho nos serviços de saúde.

Então no primeiro momento a pessoa tá ruim mentalmente eu acho que deveria sim [ser atendida na UBS], porque ela não vai ter condições de chegar até o CAPS, porque é longe, ou então ter um CAPS mais próximo. (E2)

...abrir espaço pra conversa diálogo com pessoas que são usuários e com aquelas que não usuários e colocar assim, tipo convidar as pessoas que era ex usuário e colocar o ponto de vista dele, o que fez ele começar e não usar mais, a experiência de vida dele, da pessoa. (E4)

Antes a gente fazia palestra na escola, tinha um relacionamento com os pais das crianças na creche, a gente procurava fazer a parte de autoestima com os funcionários da creche, com os pais também. Então a gente tenta ver, fazer esses grupos. (E4)

Deveríamos fazer grupo que nem esses que juntam as pessoas que usam e com dependentes químicos, assim, se eles viessem, né? Na reunião. Porque antigamente aqui, antigamente, um dois, três anos atrás, a Doutora...[médica da ESF], ela fazia um grupo. Era de dependentes de álcool e droga, né? Fazia. Mas poucas pessoas participavam. Tanto que não tem mais o grupo, acabou. E ela passava remédio, para pessoa parar de fumar, entendeu? E ela passava por esse grupo aqui. Porque tanto era para a família como era para 0 usuário. (E6)

Porque se fosse na comunidade, a gente chamava só aquelas pessoas que seriam usuárias de droga, chamava alguém para dar uma palestra, que nem já fez o pessoal do AA, Alcoólicos Anônimos... Então, teria que ter um espaço 
Heloisa da Veiga Coelho

fechado para poder estar trabalhando com essas pessoas, dependente químico. (E6)

... Ás vezes a gente vai atrás da pessoa, atrás da mãe dele, vai procurar saber o que aconteceu (...) mas a gente tem que garantir mais ou menos esse acompanhamento. Olha, tem um vínculo lá, o paciente não veio. Olha, vamos na casa, vamos ver o quê aconteceu, vamos voltar lá, vamos falar pra esse paciente - olha você tava indo, o fulano lá do CAPS que você sabe quem é, que construiu o vínculo, ligou pra perguntar de você. Porque que você não quer ir? - se for o caso ir junto com a pessoa. Será que o usuário, é pegar na mãozinha, a gente leva. Ás vezes essas pessoas não tem família, na maioria das vezes não tem ninguém no mundo (...) Eu não teria tempo pra levar. Não assim, mas eu acho que é algo que eu acho que poderia ajudar, não que eu possa fazer. Eu poder já é outros quinhentos. (E7)

A gente vai ter que fazer um trabalho da saúde do homem, que a gente sabe que é mais prevalente no homem, no sexo masculino, e uma das questões que a gente vai abordar é isso [alcolismo]. A gente vai abordar o usuário de álcool, cigarro também. (E8)

Invariavelmente esses que vem, que eu tô falando, depois de recaída. Esses são pacientes que se você se abrir um pouco pra ouvir, entendeu? Se por exemplo, for o caso, passar um tranquilizante tipo benzodiazepínico, já ajuda bastante... Eles estão precisando apenas de um apoio que ás vezes é o remédio. E a gente ter um tempo pra ouvir funciona. $E$ esse paciente normalmente volta, esses voltam, durante algum tempo, né? Esses pacientes normalmente não precisam de CAPS, entendeu? Dá pra gente segurar aqui, e tem tipo, até onde a gente consegue ver porque não é feito nenhum trabalho, não tem nenhuma estatística, mas tem um dado onde a gente pode dar resposta, tem tido um bom resultado. No início [período de intervalo entre as consultas] é 20 dias, de 15 a 20 dias, depois vai evoluindo naturalmente passa a ser mensal e depois bimestral. (E9)

Eu vejo [espaço para discutir a questão do consumo de drogas entre os trabalhadores] dentro das reuniões, que é um espaço bem mínimo, muito pequeno... Caber, caberia [ampliação dos espaços de debate sobre álcool e drogas], só tempo que é muito pequeno pra tanta coisa, pra tanto caso, de 
Heloisa da Veiga Coelho

álcool e droga que a gente vê que tem na área, deveria acontecer mais tempo pra discussão desse tema... Acho que aumentar o horário de reunião até mesmo pra discussão desse tema específico, ou uma vez por semana. (E10)

A gente [NASF] tá passando por um processo de mudança. Antes a gente tinha 19 equipes, então a gente não tinha muito tempo pra ficar principalmente aqui e no Delamare. Então agora a gente tá com 15 equipes. Então agora a gente vai desenvolver ações coletivas que é nesse momento de ações coletivas que a gente vai fazer mais grupo. Inclusive amanhã vai iniciar o grupo de saúde mental. Então algumas equipes, por isso que elas mencionaram esse grupo de saúde mental que vai iniciar. Vai ter grupo de reabilitação, vai ter mais espaço pra gente fazer as ações coletivas e preventivas. (E10)

Mesmo as propostas de práticas consideradas inovadoras e que poderiam ser espaços potentes para a ampliação do objeto das práticas direcionadas aos usuários de drogas na $A B$ (a própria ESF, o novo grupo de saúde mental coordenado por trabalhadores do NASF, o matriciamento das equipes de AB pelo CAPS e NASF e o Fórum de Saúde Mental da Coordenadoria de Saúde) apresentam como objeto dos processos de trabalho apenas o agravo em si (doença). Estes espaços não são reconhecidos e legitimados pelo conjunto de trabalhadores do serviço por serem experiências isoladas e bastante restritas.

[O grupo de saúde mental é direcionado] Pra pessoas em sofrimento psíquico. Então foi feito um levantamento na área. Inicialmente de uma equipe. Foi feito um piloto com uma equipe [ACS fizeram levantamento de todas as pessoas que estão com sofrimento psíquico], porque a gente vai começar. Daí a gente vai ver, e tem algumas pessoas que a gente vai abranger também na terapia comunitária. Aí amanhã vão ver o quê vão fazer. Vai iniciar amanhã. Não sei qual vai ser a metodologia que vai ser utilizada (...) A ideia inicial era um grupo de casos que desse para tratar no grupo. Mas aí começou a vir esquizofrenia, casos que o paciente queria matar, não fazia o perfil do grupo. Teve que dar uma parada, então agora fez o levantamento. (E10) 
Heloisa da Veiga Coelho

Eu sei que tem uma reunião de saúde mental aqui, mas eu não sei qual é a proposta (...) Eu não participo da reunião do NASF. Então, eu não sei. Mas, eu desconheço. (E1)

Então, aqui tem o trabalho com a saúde mental na UBS, que acaba englobando tudo. Se eu não me engano esse profissional é do CAPS. Agora eu não sei se é do ad ou do CAPS adulto.Todas as terças-feiras tem uma reunião e esses profissionais vem fazer o matriciamento, uma discussão dos casos aqui. Uma com o serviço social e outra com as equipes do PSF. Então, os casos são marcados e direcionados pra avaliação dessa equipe. Entendeu? Tem esse trabalho. Só que no dia que aparece caso de álcool e drogas a gente acaba mandando direto procurar [o CAPS ad]. (E7)

É [matriciamento em] saúde mental. Casos fora de área, que não tem PSF. São pacientes que chegam aqui pra gente, que os nossos psiquiatras, o único psiquiatra na verdade... São casos que são discutidos pra ver... discute com o psiquiatra qual é a conduta dele, se o paciente vai tratar com ele, se ele vai mandar pra algum outro lugar, se o ideal é ele participar de algum grupo, são pacientes que não. Para os que são do PSF tem a psiquiatra que é do NASF e pode atender. (E8)

Tem o fórum de saúde mental, que acontece toda primeira segunda-feira do mês, quando nossa psicóloga participa. Ás vezes a supervisora também vai. Nesse fórum vai CAPS adulto, os dois CAPS ad, vai prefeitura, vai psiquiatra da prefeitura, psicólogo da prefeitura. Então por isso que eu acho que a reunião é pra melhorar.Tem discussão de casos, tem caso que, às vezes, tava numa UBS só, e ai é trazido nesse fórum e todos ficam sabendo, inclusive a SUVIS também, supervisão de vigilância em saúde. (E10)

Antigamente a gente tinha reuniões mensais da equipe de saúde mental (...) da região, que eram realizadas sempre em uma unidade que fazia parte da região. Um dia no Sekler, outro dia no Reschilian. Eu não sei dizer a partir de quando isso aí acabou (...) acho que, apesar de nem tudo a gente conseguir resolver, mas só o fato da gente estar vendo as pessoas, sabendo que a Heloísa tá trabalhando no CAPS da onde. A gente ter o contato pessoal, não institucional, era bom. Pra mim ajudava bem. Mas isso eu não sei porque, também não pesquisei pra saber porque, que não funciona mais. Pelo menos não tenho sabido dessas reuniões (...) Mas não tem, na realidade, aquilo que 
Heloisa da Veiga Coelho

seria o ideal que seriam essas reuniões, em que você trocaria experiências. Mas também poderia explicar quais são as dificuldades, quais são as facilidades. E não há, isso que também não há. (E9)

Para a ideia do PSF, o agente ser da área é muito bom. Ele conhece tudo, desde o esgoto a céu aberto que passa na casa dele, na casa de um paciente e na casa dele, ou enfim, todas as mazelas que tem no morro ele sabe, porque ele vive naquele lugar. Se isso é bom pras outras áreas, eu acho que, justamente, o agente ser da região, ser vizinho, é absolutamente um empecilho para cobrar do pessoal usuário de droga (E9)

Tem agora, como chama, interlocutora de saúde mental, que é a...[interlocutora], que tá organizando a agenda regulada, pra que isso (psicoterapia, terapia ocupacional, etc) fique mais próximo as datas. (E10)

\subsection{A REDE DE SAÚdE MENTAL PELO OLHAR DO TRABALHADOR: A INEFICÁCIA DO MODELO DE ATENÇÃO BIOMÉDICO E PRIVATISTA NA AB}

Os trabalhadores (E1, E2, E4, E7, E9) percebem que a rede de atenção e cuidados direcionados aos usuários de drogas é estruturada de forma deficiente. A análise destes trabalhadores pontua a desintegração entre os equipamentos de Saúde Mental e os serviços da $A B$, além da ineficácia do modelo de atenção de saúde mental no município, apontando que as práticas dirigidas aos usuários de drogas são ilhas de excelência, ou não. De incompetência ou não, funcionando absolutamente como ilhas, entendeu? (E9)

Parece que a gente não está integrado mesmo. Parece assim, que eles não entendem o trabalho da gente. Eu sinto que, pelo menos o CAPS que a gente trabalha, eu sinto que eles estão muito fechadinhos, e, por exemplo, eu acho que é até uma característica do próprio CAPS. (...) Eu atendendo os adolescentes de escolas que me encaminham muito. É a dificuldade escolar, é a agressividade que aos poucos eu fui aprendendo a lidar... A relação da gente com o CAPS é muito ruim. E se a gente não tem essa relação, eu 
Heloisa da Veiga Coelho

percebo assim. Que quando a gente encaminhar... eu tenho muito medo até de encaminhar. Quando eu encaminho eu tenho a impressão que eu perco o paciente porque ele não vai nem pra lá e nem volta então a gente tem trabalhado muito no sentido assim, de aumentar esse vínculo com a unidade, de trabalhar aquilo que a gente pode, e se a gente não estiver dando conta aí encaminhar pra um serviço. (E1)

A gente tem o encaminhamento. Só que a contra referência não tem na discussão. Do paciente que realmente tá na área. $A$ discussão dos profissionais do CAPS, eu acho muito isolado. Você encaminhou, a UBS encaminhou, tudo bem tá encaminhado. Mas não tem a contra referência do acompanhamento, né? Porque já tá encaminhado então lá que resolve, não tem essa parte do CAPS tá encaminhando pra gente, tá fazendo, discutindo, esse paciente tá vindo direitinho, tá sendo acompanhado no CAPS ou se ele faltou hoje, dá para vocês verificarem porque ele tá faltando no atendimento, isso não tem. (E4)

Então, pelo menos nos CAPS que eu tenho contato eu não percebo que é uma coisa assim, vamos trabalhar junto, como que tá aí? Vem aqui... Vamos trabalhar com vocês. Então, quer dizer, o que eles querem é que eu encaminho pra eles, entende? Encaminhou, cortou o vínculo, uma coisa super técnica. E que na hora da intervenção acho que não funciona... Um ou outro caso pode até pode funcionar... Mas daí, o que acontece? Daí eu perco. O paciente não vem mais. Aí depois de uns seis meses eles voltam. Ah! Eu fui lá, mas não deu certo por isso ou por aquilo e volta... Eu acho que faltava essa integração mesmo da unidade básica de saúde com o CAPS. (E1)

Não [houve contratação de novos trabalhadores da Saúde Mental]. Ao contrário, os colegas estão saindo, porque há um achatamento salarial e os colegas tem tido mais vontade de fazer outras experiências. Aí a maior brincadeira é que: a gente que tá no bico do corvo não vai sair pra fazer mais experiência, tentar novos empregos. Não dá. Então a gente fica aqui devagarzinho esperando a aposentadoria (...) Eles me usam de referência pra muitos (outros serviços da região). Assim, é exclusividade. Eu sou o único (psiquiatra) por aqui. (E9) 
Heloisa da Veiga Coelho

Então, eles [trabalhadores do CAPS ad] tiveram aqui há um tempo. A gente até fez uma proposta pra eles, pra gente fazer o trabalho de prevenção, mas parece que não era ainda o momento do CAPS, não sei. (E7)

Eu acho que falta uma integração da rede. A rede tá trabalhando solta, mole. Vamos dizer assim, cada um faz o seu trabalho. Não tô dizendo que é ruim ou bom, mas cada um faz o seu trabalho. Mas eu não tenho uma ligação com o CAPS, o CAPS não tem uma ligação pra mim, entendeu? A não ser quando o paciente tem uma alta e eles mandam do CAPS pra cá (...) No meu modo de ver. Pode ser que em outro lugar, em outra área, tenha essa integração e eu que seja o caso absolutamente fora do quadro. (E9)

A impressão que, talvez... Acho que a gente [UBS e CAPS] precise falar a mesma língua ... de que forma é esse trabalho? A gente sabe que tem um fluxo, que tem todo um processo de atendimento com relação ao álcool e drogas. Mas a gente não tá... até que ponto isso aí... é como você falou aquele dia na reunião, alguns querem, outros respondem, outros esperam, outros gostam de frequentar o lugar outros não. Mas não tem outra alternativa... (E7)

Com certeza (psicoterapia e outros instrumentos) acho que ajudaria. Mas você sabe, na nossa área tem o... [psicólogo], da Vila das Mercês, que anda sobrecarregado, eternamente sobrecarregado. Na verdade eu mando quando há realmente uma vontade muito grande do paciente, de ter mais tempo, que o psicólogo oferece mais que o psiquiatra. E sempre contando com a boa vontade do colega lá, do João, porque realmente não existe, aqui no nosso posto não tem psicólogo, a nossa referência seria o... [psicólogo]. (E9)

Eles [usuários de drogas] preferem [tratamento] se for dentro da unidade. Muitas vezes eles vão aderir só até o ponto em que a unidade permite, a partir do momento em que a unidade não tem mais o que fazer, tem que ser encaminhado pra fora, aí eles muitas vezes não vão. Às vezes até vão uma ou duas vezes, mas é medo, receio, não sabe o que vai acontecer lá, não sabe se vai ser bem atendido ou não, aí eles não vão não. (E2)

E aí a gente encaminhou [para o CAPS]. E aí ele ficou acho que um mês frequentando e aí também não gostou, porque era... não quis continuar $e$ acabou voltando pro Rio de Janeiro. A gente não sabe se ele voltou pra usar 
Heloisa da Veiga Coelho

droga, mas o comentário da família é que se ele voltasse provavelmente ele voltaria com tudo. (E7)

O discurso de alguns trabalhadores (E1, E3, E9) apresenta o (des) conhecimento em relação à realidade de saúde mental das pessoas que vivem no território e à contradição entre essa realidade e as intervenções de saúde produzidas pela rede de saúde do município.

Mulheres. Imensa maioria [demanda da psiquiatria]. A mulher já é mais sensivel, a mulher consegue falar mais, não tem aquele negócio de machão de "eu tô sofrendo, mas não vou dizer". Vou contar pra outro cara que eu estou sofrendo? Meu sofrimento, tipo... e principalmente o sentimento, que é um sentimento tipo psicológico, emocional, que não é de bom tom com um cara macho, entendeu? Ser deprimido, chorar,né? A disponibilidade que ela [mulher] tem. Como ela não trabalha como o homem trabalha, isso tem mudado, mas ainda, e principalmente, na periferia, que a gente tá na periferia, é uma verdade. Muito mais homem trabalha do que mulher. A mulher tem disponibilidade inclusive de vir pro posto. E isso você já trabalhou, você sabe, tem gente que vem pro posto como um programa social. Um alguém que vem buscar um remédio e conversa com uma vizinha. É um programa social vir pro posto. Aí aproveita e marca a consulta com o psiquiatra, então essa disponibilidade da mulher, ainda que ao meu ver é um motivo de ter mais mulher no posto. (E9)

Então, quando eu fiz o banco de dados, eu me lembro de que a primeira causa de procura da unidade eram doenças ligadas ao fator emocional, tipo dificuldade escolar, transtorno do déficit de atenção e hiperatividade, então tinha uma demanda importante...mas eles [trabalhadores da UBS] nem conhecem o banco de dados, não foi de interesse da prefeitura (...) no início, eu queria muito a ajuda do CAPS e aí lá eles só queriam atender o autista e o psicótico, mesmo que isso seja uma percentagem tão pequena... Mas eles nunca nem tentaram dar um subsidio pra gente, um treinamento de como lidar com essas questões [outras demandas de Saúde Mental] que chegam todos os dias. (E1) 
Heloisa da Veiga Coelho

O que prevalece são outros casos de saúde mental como a esquizofrenia, depressão, aparecem também casos de álcool e drogas. Porém, o que ultrapassam são os casos de doença mental como esquizofrenia, mas vêm também esses de droga. (E10)

É esquizofrenia [o diagnóstico do paciente]. Mas se ele tivesse cuidado lá no comecinho dava pra ser uma coisa controlada, mas agora eu acho que não. Tá atingindo a parte motora dele, sabe? Acho que já atingiu tudo. (E5)

Esse equipamento [CAPS] existe. A necessidade dele existir se justifica. Os profissionais que estão alocados ali são necessários. É um corpo clínico necessário para dar resposta a essas questões... Mas qual a proximidade disso com a nossa realidade? Com a necessidade do paciente? Ah! Então quer dizer que se estivesse do lado da porta do cidadão ele iria frequentar? Não obrigatoriamente. Não é isso que mobiliza a pessoa para frequentar. (E3)

Alguns trabalhadores (E2, E3, E6, E7, E8, E9) apontam a desintegração da rede de saúde, o que fere um dos princípios do SUS que diz respeito à Integralidade das ações. O processo de produção dos serviços de saúde é pautado na somatória e não na integração de diferentes processos de trabalho e de diferentes conhecimentos. É um serviço que se configura numa somatória de trabalhos individuais sem constituir um trabalho coletivo. Os trabalhadores da $A B$ (individuais e não coletivos) não compartilham do processo de trabalho dos colegas e muito menos dos processos de trabalhos e práticas dos trabalhadores de outros serviços. Estes conhecem o funcionamento da rede de serviços de Saúde Mental do município a partir de manuais e fluxograma apenas. Essa desintegração impacta também de forma negativa a produção de cuidados para as pessoas com problemas relacionados ao consumo de drogas.

Porque o... [paciente atendido pelo sujeito da pesquisa], eu encaminhei ele pro CAPS, mas não é todo mundo que vai pro CAPS. [Entrevistadora] Por que será que eles não vão? Não sei. (E6) 
Heloisa da Veiga Coelho

Muito pouco. Muito pouco [relação com NASF]. Na verdade o NASF dá mais um suporte para o pessoal do PSF, mas eu sinceramente eu não sei como é que isso tá andando, como é que tá a dinâmica disso. Como é que tá. (E9)

Mas, também do ponto de vista, assim, de construção, às vezes até a sensação que eu tenho - eu vou falar uma bobagem - até a sensação que eu tenho é que a gente ainda é muito rudimentar. Muito rudimentar. Tem falta de... Na unidade de saúde a gente faz esse exercício, é quase um desafio todos os dias, né? Da gente construir isso, né? O médico conversar com a enfermeira, o enfermeiro conversar com o assistente social, o assistente social conversar com o técnico de enfermagem, quer dizer, ele não é o paciente, o paciente é um ser, não um número, ele não é dividido, um pedaço de cada um, né? (E3)

Tudo estoura aqui, né? Tudo. Até aquele caso que eu acabei de te falar, né? Aqui é a porta, a gente identifica tudo que passa, desde o terciário que a gente põe na ambulância e reza, e pede - Gente, pelo amor de Deus que alguém opere. Quando ele não volta. Bate no hospital e volta, puf, puf. Até o usuário de droga, tudo a gente vê... (E7)

Ah, o agente de saúde passou na minha casa e ela me ofereceu ajuda, então vou bater lá no posto. Eles acham que todos os problemas deles tem que ser solucionados aqui, o que não é verdade. (E2)

Porque não é tudo que o programa (ESF) vai conseguir acolher. É claro que a gente vai ter aquele acompanhamento, a gente vai estar sabendo o quê está acontecendo com aquele usuário, só que ele vai estar passando em algum outro lugar também. Mas ás vezes nesses outros lugares eu não consigo... (E8)

Segundo alguns profissionais de saúde (E1, E2, E9) as limitações da $A B$ apontadas acima tem relação com o modelo de atenção hegemônico nesse nível da atenção, centrado na doença/agravo e que reproduz a lógica mercantil de saúde/doença como mercadoria. 
Heloisa da Veiga Coelho

$\mathrm{Na}$ atual administração eu não aguentei a cobrança, a proposta de você trabalhar por... só por produtividade. Aí eu larguei a chefia (...) achei que era muito mais importante eu atender os adolescentes do que ficar cobrando produtividade dos médicos e aí estou aqui hoje. (E1)

Mas eu acho que só faz isso mesmo. Que é pra isso que o PSF tem que ser, pra procurar a demanda. Eu acho... eu sou favorável ao PSF, sou absolutamente favorável ao PSF. Como funciona é outra coisa. Mas o fato de ter gente na rua, de casa em casa, vendo o paciente, antecipando a necessidade, eu acho isso fundamental. Como funciona é outro departamento. O PSF não sei se é aqui, isso aqui não é uma crítica, não ficam os profissionais do PSF. Esse é um problema que eu não sei identificar e nem cabe a mim identificar. Mas o que se troca principalmente de médico e enfermeira, enfermagem, né? É uma grandeza. Não sei se você já se deu conta, já né? Você não consegue, se você vier fazer essa pesquisa daqui há dois meses você vai encontrar nenhum profissional com quem você tenha falado da outra vez, a não ser eu, ou os da prefeitura. Eu acho que há uma dificuldade. Primeiro, os agentes acho que não tem nenhuma, não é nem formação. Não tem nenhuma informação sobre como abordar. (E9)

Ao trazerem a impotência do trabalhador de saúde diante das demandas do consumo de drogas na $A B$ estes trabalhadores (E4 e E5) expõem justamente a falência da rede de saúde diante do fenômeno.

E aí quando ele ficava naquele... na crise mesmo, do uso dos dois [álcool e cocaína], ele subia em cima do telhado, queria se matar. Aí a gente pedia pra vir bombeiro, SAMU. Aí, muitas vezes o bombeiro tinha que tirar ele lá do telhado. Ah, quantos anos ele tem? 22 anos. Então tem que chamar a polícia. la chamar a polícia. A polícia fala: Por que que chamou? Então não tem quem te respalda. Quantas vezes a gente falava assim: Não. Tem que chamar o médico, porque a gente, nós segurar a pessoa que tá drogada é difícil. Aí ele puxava a faca pra gente. Então assim, como é que eu vou controlar uma pessoa assim? Mesmo um profissional da saúde, é muito difícil. (E4)

Porque é um hospital especializado. E pegaram ele também ali, ele entrou como pronto socorro ali também, né? Porque não é fácil o acesso também, 
Heloisa da Veiga Coelho

né? Ali não é fácil, fechado. Ele entrou como PS mesmo porque ele tava quebrando a casa, se não me engano. Aí chamaram a polícia, a polícia levou ele pra lá, pra esse hospital. Tava alcoolizado na hora, né? E a polícia levou e o que acontecia era isso. Quando ele tava bêbado ele tava tomando a medicação, acho que carbamazepina e respiridona, uma coisa assim que ele toma tava misturando com bebida. Entendeu? (E5)

Ah, então, daí levou pro CAPS e aí no CAPS eles falaram assim: ah! Tem que tentar fazer com que ele venha. Mas ele não vai sozinho!!! Quantas vezes eu pegava, marcava a agenda, aí eu chegava lá na casa, aí ele tava todo molhado. Outro dia ele tava até puxando fogo, porque ele tava debaixo da cama, todo molhado com um litro de vodka, que ele misturou vodka com cocaína, e tava todo molhado. (E4)

Esse modelo de atenção mercantilizado, centrado no agravo em si e que não permite a ampliação do objeto do processo de trabalho e nem a transformação das demandas que chegam em necessidades de saúde por parte dos trabalhadores, não permite que o serviço de saúde ofereça respostas adequadas às demandas do cotidiano relacionadas ao consumo de drogas. Isso gera sofrimento para os trabalhadores da $A B$. Esse sofrimento foi apontado apenas por alguns entrevistados (E3, E7, E8) que reconheceram esse sofrimento em si e/ou nos outros colegas.

Pode vir [demandas relacionadas ao consumo de drogas] através do médico, do enfermeiro, do agente de saúde bastante. O agente comunitário de saúde ele está na ponta da relação com o paciente, com a família, ele sofre, ás vezes. Vivencia essa situação, como ele é do bairro, ele conhece. Então assim, quando a gente encontra e atende no corredor. A pessoa te vê e fala: Ah!!! Tenho um caso pra te falar. E essas situações elas exigem, demandam um pouquinho. Até parece que não, mas numa conversa informal ela trás tanta informação importante. Talvez a necessidade daquela pessoa naquele momento é compartilhar com alguém aquilo que ele vê ou que ele viu na visita ou que ele recebeu no campo, com o paciente em consulta. Ele tá muito angustiado. E naquele momento ele precisa compartilhar. Uma coisa é a gente compartilhar, né? E a gente pode compartilhar, dependendo do caso, a gente 
Heloisa da Veiga Coelho

pode fazer isso escutando no corredor, na cozinha, no banheiro. Mas tem algumas situações que logo que a conversa começa, a gente fala: Não, não, peraí, peraí, vamos sentar eu quero anotar tudo isso aí que você está me falando eu preciso saber, detalhes sobre essa pessoa, sobre essa família. A gente conversa, recebe a solicitação e daí vê o que é necessário, vê o quanto a gente vai fazer conjuntamente. A gente vai fazer uma visita, a gente precisa saber um pouco mais sobre esse paciente, a gente precisa identificar um cuidador, cada caso é um caso. A gente percebe que isso é frequente. Tudo com relação à unidade, aos funcionários. O usuário também, o usuário pode ser paciente. Ele também vem. Ou como usuário de droga também vem. (E3)

Gosto [de atuar na ESF], apesar das dores (...) Então, é difícil. É pra deixar bem angustiado, se a pessoa não tiver um... agora estou falando do profissional, se não tiver uma saúde mental boa fica meio doidinho, porque são tantas demandas. (E7)

Agora que você falou de frustração, esse é um dos casos que a gente fica frustrado. Não só no caso de usuário de álcool e droga, droga ilícita e lícita, mas também com os pacientes de saúde mental. A gente vê que ainda falta muita coisa pra ser feita pra eles, a gente chega até o limite. Dali pra frente a gente não consegue mais agir, precisaria de outros recursos de outras instâncias, e as vezes a gente não tem pra onde, não existem essas instâncias, e quando tem a gente não vê resposta. Então, eu acho que são duas áreas que precisam ainda ser... ter mais políticas de saúde, ter mais coisa pra dar um suporte mesmo pra gente. (E8)

Apenas um entrevistado (E10) aponta melhorias quantitativas na rede de Saúde Mental da região a partir da iniciativa dos gestores em potencializar e reestruturar essa rede de atenção. Essa opinião destoa do tom crítico sobre a rede que os outros trabalhadores entrevistados trouxeram em seus depoimentos.

Então, tá sendo reorganizado [a Saúde Mental na região]... A gente [NASF] presta serviço com a prefeitura, mas a gente faz essa articulação junto com os médicos, a gente depende da agenda regulada também, quem supervisiona essa agenda regulada é a prefeitura. (...) Nesses três anos melhorou [Saúde Mental], na região do Ipiranga, eu digo que nessa região. Quando eu entrei só 
tinha um CAPS, que era o CAPS Arapuá. Depois de algum tempo o CAPS Sacomã, depois de algum tempo o CAPS adulto da Vila Monumento. E aí já entrou também essa questão também dessa articulação desses três CAPS e inclusive a articulação da rede, da agenda regulada. Então fica o NASF, os CAPS, mais a Prefeitura tudo redondinho pra trabalhar junto, então a saúde mental tá trabalhando junto, do Ipiranga, então eu acho que melhorou. Não redondinha assim, mas tá melhor. [É necessário] Ter mais profissionais, mais vagas, mais equipamentos. (E10) 
Diécuésana 



\section{DISCUSSÃO}

Historicamente os serviços de saúde voltados para usuários de drogas mostram-se restritos, não apenas em relação a aspectos quantitativos, como em relação aos tipos de abordagem e intervenção produzidos por estes serviços (Soares, Rohden, 1994; Brasil, 2007). Eles reproduzem o modelo biomédico e psiquiátrico hegemônico até os dias atuais na produção de serviços de saúde direcionados às pessoas que fazem uso prejudicial de algum tipo de substância psicoativa. Este modelo se caracteriza por uma excessiva patologização e medicalização da vida e do processo saúde-doença (Teixeira et al, 1998; Alves, 2009).

Quando os trabalhadores da AB são interrogados acerca da atenção aos usuários de drogas nesse nível de atenção a problematização sobre a incoerência entre as demandas que chegam, o processo de produção de serviços de saúde nesse nível de atenção e o modelo assistencial vigente, configura-se de forma bastante superficial, haja visto que a precarização do trabalho, por exemplo, não seja alvo de discussão entre os trabalhadores quando estes são interrogados em relação ao processo de trabalho do qual participam. As formas de contratação, a ausência de planos de carreira, os salários (no caso de trabalhadores estatutários) e a ausência de estabilidade não veem à tona, ainda que a discussão esteja em torno do trabalho. Dessa forma, ficam de fora da equação as condições de trabalho, como ritmos de trabalho extenuantes, cobrança por produtividade, ausência de espaços para reflexão sobre os processos de trabalho e de produção dos serviços de saúde e distanciamento dos espaços de formulação das políticas públicas.

Todas essas transformações no mundo do trabalho, que também afetaram a área da saúde, estão diretamente relacionadas à reestruturação produtiva e à investida do neoliberalismo a partir da 
década de 1970 (Antunes, 2006; Santos, 2007; Shimizu, Carvalho Jr, 2012).

As condições de trabalho na $A B$, diretamente influenciadas pelas transformações ocasionadas principalmente pela onda neoliberal que atingiu o setor saúde, produzem ambiente de trabalho propício à alienação do trabalhador, além de sentimentos como impotência, estresse, medo, insegurança, baixa auto-estima (Ribeiro et al, 2004).

Todos esses sentimentos foram trazidos pelos sujeitos desta pesquisa quando questionados sobre como lidavam com demandas relacionadas ao consumo de drogas. Mas as justificativas em relação a este sentimento recaiam, quase sempre, sobre a culpabilização do próprio sujeito. Não se apresenta qualquer análise estrutural ou das dinâmicas que conformam as condições de trabalho, o que mostra a inexistência dessa discussão, e de espaços e condições favoráveis para reflexão sobre as formas de organização e gestão dos processos de trabalho e de produção dos serviços de saúde na $A B$ (Ribeiro et al, 2004).

$O$ trabalho na $A B$ continua a ser concebido de forma fragmentada, parcelar e isolado, mesmo com a proposta da reestruturação desse nível da atenção, a partir da implantação da ESF e não há ruptura com 0 modelo assistencial predominantemente biomédico e com as formas hegemônicas de produção das intervenções em saúde (Favoreto e Camargo Jr., 2002; Ribeiro et al, 2004; Scherer et al, 2005).

Algumas condições que envolvem os processos de trabalho dentro dos serviços de $A B$ dificultam ou impedem o processo de transformação do modelo assistencial vigente proposto pela ESF (Favoreto e Camargo Jr., 2002; Ribeiro et al, 2004; Scherer et al, 2005). Segundo Ribeiro et al (2004) as dificuldades para a mudança do modelo assistencial vigente e transformação das formas hegemônicas de se produzirem as práticas em saúde na $A B$ ocorrem devido: 
(1) a imposição dos programas pelo MS; (2) o fato de serem totalmente normatizados no nível central; (3) o fato de serem financiados por incentivos financeiros internacionais; (4) a obrigatoriedade, na prática, de sua adoção pelos municípios; (5) a desconsideração da enorme heterogeneidade dos municípios, na oferta de serviços de saúde; (6) a ausências de redes regionalizadas e hierarquizadas para garantir o acesso universal a todos os níveis de atenção - o que limita o atendimento dado por esta estratégia a uma simples porta de entrada sem saída; (7) a desconsideração da complexidade do quadro epidemiológico brasileiro; e, finalmente, a substituição de profissionais qualificados da Enfermagem por pessoas sem qualificação, com contratos precários de trabalho, com sérias limitações na resolução dos problemas de saúde da população (Ribeiro et al, 2004, p.442).

Nesse panorama, a autonomia dos trabalhadores para definirem as formas de organização e gestão dos processos de trabalho nos serviços de saúde torna-se bastante limitada. (Ribeiro et al, 2004; Trad et al, 2011). Estes processos são condicionados a partir de normas e fluxogramas construídos em nível central, sem pactuação entre trabalhadores, gestores e usuários dos serviços de saúde. São apenas os gestores, que pondo na mesa interesses políticos, desconsideram as formas de trabalhar e de viver das pessoas que vivem nos territórios bem como suas formas de adoecer.

Dessa forma, o modus operandis preconizado nos órgãos centrais é imposto aos diferentes trabalhadores que estão na linha de frente e que devem executar passivamente as tarefas prescritas e atingir determinado resultado esperado. Poucos são os espaços de planejamento local, poucas são as avaliações de ações, programas e projetos (que poderiam constituir espaços de reflexão sobre os processos de trabalho). Os níveis centrais realizam avaliações de forma isolada, levando-se em conta apenas dados quantitativos (metas atingidas, número de práticas produzidas). Mas nem esses dados são discutidos com os trabalhadores. A estes sobram apenas as cobranças e o trabalho técnico e vazio (Queiroz, Salum, 1996; Schraiber, Mendes-Gonçalves, 1996). 
Como consequência disso, o trabalho na $A B$ deixa de ser orgânico, vivo, por perder totalmente o sentido para este trabalhador. É mais um trabalho instrumental e sem correlação nenhuma com as necessidades da população e suas formas de trabalhar e de viver.

As falas dos entrevistados trazem à tona a falta de espaços reflexivos sobre suas práticas. Considerando que 0 trabalho em saúde configura-se como um trabalho reflexivo, uma vez que o objeto de trabalho em saúde - as necessidades de saúde, sentidas e trazidas aos serviços pelos sujeitos/usuários e apreendidas e interpretadas tecnicamente pelos sujeitos/agentes do trabalho (Peduzzi, 2002, p.83) - é extremamente complexo, torna-se imprescindível construir espaços nos quais os diversos profissionais de saúde, envolvidos na implementação das ações em saúde, construam coletivamente as práticas de saúde visando uma assistência integral e não parcelar e compartimentalizada (Peduzzi, 2002).

A ausência desses espaços de reflexão acaba repercutindo na execução de tarefas como meras justaposições, de forma que o trabalho em equipe não se configura como trabalho coletivo, que impõe a articulação e integração de diferentes processos de trabalho, com suas peculiaridades, objetivos específicos, saberes e instrumentos próprios, objetivando a transformação das condições de vida e de saúde dos moradores de determinado território (Peduzzi, 2002). Fica também prejudicado o desenvolvimento de instrumentos capazes de transformar as demandas relacionadas ao consumo de drogas que chegam ao serviço em necessidades de saúde ${ }^{5}$.

\footnotetext{
${ }^{5}$ Aqui cabe um esclarecimento sobre o termo "necessidades de saúde", uma vez que, ele pode ser interpretado a partir de diferentes bases teórico-conceituais. Neste trabalho tomamos como referencial teórico a Saúde Coletiva que entende as necessidades de saúde como necessidades de reprodução social e que tomálas como objeto das práticas em saúde requer uma compreensão ampla deste objeto em suas dimensões biológica, cultural, política, ambiental e todas essas dimensões coordenadas pela dimensão econômica, já que vivemos no modo de produção capitalista (Campos, Mishima, 2005).
} 
Ao falarem sobre as práticas direcionadas aos usuários de drogas os entrevistados identificam apenas a ineficácia das mesmas diante da complexidade do fenômeno do consumo de drogas (os elementos dessa complexidade são nebulosos) e culpam-se por essa ineficácia por conta de uma deficiência técnica em sua formação. Acreditam que a formação técnica conseguiria impactar positivamente nas suas práticas e principalmente nos resultados das mesmas. Não cogitam a importância e nem mesmo a ausência de uma formação crítica-reflexiva (e, portanto, política) sobre o fenômeno para uma compreensão ampliada do mesmo.

Alguns estudos que discutem a assistência prestada aos usuários de drogas na $A B$ pelo olhar dos profissionais de saúde também reforçam a importância da formação técnica, que não deve ser desconsiderada, mas acrescida de uma instrumentalização mais ampla, pois a formação técnica em si, que parece se resumir à formação clínica, não é capaz de promover atenção que atenda às necessidades de saúde da população usuária de drogas. Na prática, o que ocorre é que 0 atendimento às questões relacionadas ao consumo de drogas, quando acontecem na $A B$, torna-se bastante restrito. Segundo Moretti-Pires et al (2011):

\footnotetext{
Estas questões, quando aparecem, são trabalhadas apenas por um conteúdo reducionista e por meio de protocolos rígidos de diagnóstico e intervenção medicamentosa, que deixam escapar aspectos sociais, relacionais e contextuais, de entendimento necessário a uma efetiva e eficiente atuação do profissional de saúde no sentido da promoção da saúde (Moretti-Pires et al, 2011, p.220).
}

Essa formação crítica e imprescindível para a ampliação do objeto das práticas de saúde torna-se desnecessária na conjuntura atual dos serviços de saúde e, muitas vezes, inconveniente, por produzir questionamentos acerca da organização e das formas que se processam a produção das intervenções em saúde, bem como sobre as verdadeiras causas do descompasso entre essa produção e as necessidades de saúde da população (Calipo, Soares, 2008). 
Conforme anteriormente discutido, entre os elementos das considerações teóricas, os modelos assistenciais na $A B$, que constituem importantes instrumentos do processo de produção em saúde, de forma geral, são definidos conforme delineamentos políticos e programáticos. Tais delineamentos são constituídos a partir de disputas entre interesses diversos que se colocam cotidianamente nas diferentes arenas de disputas políticas e são resultados concretos de tais disputas. Trabalhadores e usuários geralmente encontram-se fora dessas arenas e apenas recebem, de forma passiva, o que os detentores do poder direcionam a estes sujeitos. Assim, os modelos assistenciais vigentes na $A B$, mesmo com a proposta inovadora de reformulação a partir da ESF, não conseguem romper com o paradigma biomédico e privatista, que direciona os processos de produção dos serviços de saúde nesse nível de atenção (Favoreto, Camargo Jr, 2002; Scherer et al, 2005; Giovanella et al, 2009; Heimann, et al, 2011).

A permanência da hegemonia do paradigma biomédico, mesmo com a implementação do SUS, vem gerando um sistema de saúde anômalo, visto que, as normas de operacionalização do SUS contradizem as suas diretrizes e seus princípios. O arcabouço político, jurídico e institucional que fundamenta o SUS propõe modelo assistencial abrangente e capaz de garantir à população acesso universal à saúde, de forma integral, equânime e resolutiva, contando com redes hierarquizadas de serviços. Isso esbarra no aspecto técnico-operacional (que tem a ver com as formas de organização dos processos de trabalho e formas de produção dos serviços de saúde) ainda pautado no modelo biomédico (Scherer et al, 2005).

A crise do paradigma biomédico, que perdura por décadas e foi propulsora da Reforma Sanitária brasileira, que propõe a ruptura com esse paradigma para superação da crise na saúde pública brasileira, não se mostrou suficiente para gerar um rompimento definitivo e alterações estruturais nas formas de se pensar e fazer 
saúde no Brasil. Esse paradigma encaixa-se perfeitamente com a ideologia neoliberal, predominante nos discursos sobre saúde no país nas últimas décadas, influenciando negativamente a implementação do SUS, sistema que se contrapõe ao paradigma biomédico, sendo considerado um novo paradigma para a Saúde Pública brasileira (Noronha, Soares, 2001; Scherer et al, 2005; Bravo, Menezes, 2007).

O processo de produção de serviços de saúde, influenciado pelo paradigma médico-assistencial privatista, também não permite aos trabalhadores estruturarem seus processos de trabalho a partir do trabalho coletivo. Percebe-se que os distintos processos de trabalho que coexistem no espaço físico da UBS não são interdisciplinares e resultam apenas numa soma de processos de trabalho que não compartilham do mesmo objeto como apontam Queiroz e Salum (1996) e Peduzzi (2002). Queiroz e Salum (1996) apontam que:

Com o trabalho coletivo há um resgate da natureza
coletiva dos sujeitos da prática sanitária sem que isso
implique o desconhecimento de suas dimensões
individuais. [...] São trabalhadores coletivos que
desenvolvem processos cooperativos que não são
meramente a soma dos processos de trabalho e
habilidades dos conjuntos dos membros da equipe
multiprofissional (Queiroz, Salum, 1996, p.10).

Por conta das formas organizacionais e gerenciais dos serviços de $A B$, pautadas nos modelos tayloristas e fordista, mas com influência do novo modelo toyotista (planejamento estratégico, gerenciamento flexível e participativo e projetos de qualidade), os entrevistados não se propõem a articular e recompor os trabalhos dos diferentes profissionais dentro deste espaço, nem mesmo reconhecer a complementaridade e interdependência de suas ações (Peduzzi, 2002).

Esse modelo assistencial biomédico é também hegemônico em outros níveis de atenção e influencia a constituição das redes de saúde, especialmente a rede de Saúde Mental. Esta se configura de 
forma fragmentada, como apontam os entrevistados, incapaz de articular os diferentes serviços de saúde para produzir os cuidados de saúde para pessoas que consomem drogas e também incapazes de alterar os objetos do processo de trabalho, que continuam restritos à doença (Moretti-Pires et al, 2011; Delfini et al, 2009; Vecchia, Martins, 2009; Munari et al 2010; Vannucchi, Carneiro Jr, 2012).

O processo de produção de serviços de saúde é sustentado e diretamente influenciado pelo aparato jurídico, político e ideológico, que são engendrados pelo Estado e condicionam a organização da sociedade. As formas atuais de produção dos serviços de saúde na $A B$ e organização dos processos de trabalho das distintas categorias de trabalhadores da rede de saúde são influenciados por concepções e ideologias hegemônicas e de padrão neoliberal (Noronha, Soares, 2001). Tais concepções seguem em direção oposta aos princípios do SUS, priorizando a atenção desintegrada, parcelar, sem uma rede constituída (apenas um conjunto de serviços que não se inter-relacionam) com ações focalizadas e direcionadas a grupos sociais específicos. Segundo Noronha, Soares (2001):

\begin{abstract}
As políticas sociais e de saúde perderam sua dimensão integradora, tanto no âmbito nacional como no âmbito regional e estadual, caindo numa visão focalista onde o "local" é privilegiado como único espaço capaz de dar respostas supostamente mais "eficientes" e acordes às necessidades da população. Retrocedemos a uma visão "comunitária" onde as pessoas e as famílias passam a ser as responsáveis últimas por sua saúde e bem-estar. Por trás de um falso e importado conceito de empowerment está o abandono por parte do Estado de seu papel ativo e determinante nas condições de vida da população, particularmente quando parcelas majoritárias e crescentes da mesma estão na mais absoluta pobreza (Noronha, Soares, 2001, p. 446).
\end{abstract}

Em última instância, são os trabalhadores que executam as políticas sociais, especialmente as de saúde e por se encontrarem afastados das arenas políticas que definem tais políticas, não assumem uma postura crítica e reflexiva em relação ao desmonte do Estado brasileiro e crescente desresponsabilização das três esferas 
do governo das suas atribuições na área da saúde. Os espaços de trabalho favorecem que os profissionais da saúde permaneçam alheios aos fatores que determinam o processo de produção dos serviços de saúde. Por conta disso, o trabalho destes sujeitos tornase fragmentado, parcelar e sem resolutividade, pois não dialoga com as necessidades de saúde dos usuários dos serviços (Queiroz, Salum, 1996; Schraiber, Mendes-Gonçalves, 1996; Ribeiro et al, 2004).

Quando o trabalhador de saúde toma o usuário de drogas como objeto do processo de trabalho alguns aspectos relevantes devem ser considerados para a análise dos fatores que estão envolvidos nessa relação entre estes sujeitos (trabalhador/usuário).

O primeiro aspecto a ser pensado nessa relação são os conceitos e/ou pré-conceitos que ambos possuem em relação a si mesmo, ao outro e ao fenômeno do consumo de drogas. Estes aspectos influenciam a construção do discurso destes sujeitos sobre drogas e, por conseguinte, desenharão as relações entre eles.

Os entrevistados reproduziram as concepções hegemônicas em relação ao usuário de drogas e em relação ao consumo de drogas. Esse discurso coloca o usuário de drogas na posição de fraco, vulnerável, marginal e perigoso. Nesse sentido, os trabalhadores adotam um posicionamento de culpabilização desses sujeitos frente ao consumo de drogas e sua total responsabilização diante do sucesso/fracasso das intervenções de saúde promovidas pelos serviços de saúde. Este mesmo discurso, que se utiliza das concepções hegemônicas sobre os usuários de drogas para se configurar, se reproduz também em outras instituições como nos mostra o estudo de Soares et al (2009)

$\mathrm{O}$ dimensionamento, em termos de envergadura e complexidade do fenômeno do consumo de drogas, fica prejudicado pois, não se incluem na análise aspectos como as desigualdades sociais, provocadas pela exploração capitalista globalizada, que concentra ainda mais as riquezas, os aspectos econômicos das 
drogas (que constituem mercadorias bastante rentáveis) e as repercussões dos valores contemporâneos, reproduzidos socialmente, e que influenciam as formas de trabalhar (produção) e de viver (consumo) das pessoas (Soares, 2007). O que analisa-se então, a partir dos discursos dos participantes nesta pesquisa, é o tratamento superficial da questão, facilitando-se a reprodução acrítica de conceitos sobre o fenômeno, enraizados no senso comum.

Tal achado dialoga com as considerações feitas por Richard Bucher (1996), que discute enfaticamente a ideologia presente no discurso proibicionista, pontuando que há interesses, muitas vezes escusos e camuflados, por trás do discurso hegemônico de guerra às drogas (Bucher, 1994, 1996). Ao discutir os estereótipos em relação ao usuário de drogas o autor aponta que:

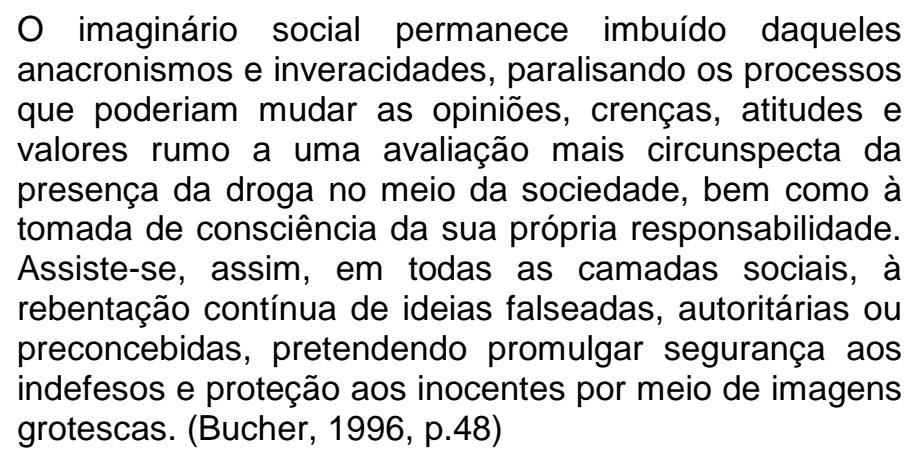

Acselrad (2005) retoma classificação amplamente utilizada no mundo e que vem ancorando o discurso dos modelos de prevenção de drogas e, podemos dizer também, ancora também os modelos de práticas em saúde direcionadas aos usuários de drogas. Essas classificações são elaboradas a partir das três variáveis consideradas pertinentes no discurso preventivo hegemônico quando se fala de uso indevido de drogas: o produto, o indivíduo e o contexto/meio sociocultural.

Assim, de acordo com a compilação de Acselrad (2005) os modelos são: jurídico-moral, da saúde pública, psicossocial e sociocultural. 
No modelo jurídico-moral o consumo de drogas é considerado desvio social e crime. As práticas nesse modelo têm como finalidade manter os sujeitos afastados de qualquer tipo de consumo. Eles se utilizam de informações (muitas vezes enviesadas) sobre os prejuízos, danos e perigos do consumo de drogas, especialmente as ilícitas, legitimando as ações repressivas, de combate às drogas (consumo, venda e produção) além dos "tratamentos corretivos" como internações compulsórias, torturas e castigos. Criminaliza-se todos os sujeitos implicados na cadeia produtiva das drogas, inclusive o usuário. Esse modelo retoma as concepções do paradigma proibicionista (Soares, Jacobi, 2000).

O modelo da saúde pública reforça a eliminação do consumo de todas as drogas, pois o consumo é considerado doença, sendo a droga o vetor, o indivíduo o hospedeiro e o ambiente apenas um pano de fundo do consumo. Nesse discurso a sociedade é tida como indefesa diante da droga que aqui adquire a capacidade de por si só subverter a sociedade ao seu domínio. As práticas enfeixadas sob este modelo também se utilizam de informações sobre drogas, através de campanhas que ajudem a sociedade a resistir ao apelo do consumo, não levando em conta os desejos e as vontades dos sujeitos. Para aqueles que não resistem a estes apelos, o caminho para a desgraça já está determinado e a única saída possível é o isolamento para que não "contaminem" o restante da sociedade. Estes dois primeiros modelos citados acima sustentam as concepções do paradigma hegemônico do proibicionismo (Soares, Jacobi, 2000).

O modelo psicossocial resgata a responsabilidade do indivíduo no consumo de drogas. Este sujeito torna-se o ator principal e o consumo de drogas passa a ser considerado um comportamento humano. As práticas visam também à abstinência através de mudanças no comportamento, enfeixadas na concepção da Promoção da Saúde. Utilizam-se informações mais claras e objetivas e não tão enviesadas e os sujeitos "empoderados" 
participam ativamente na transmissão dessas informações, legitimando as mesmas, sem questionamentos. Estes sujeitos são considerados atores principais da sua história, porém, em caso de fragilidade, o processo de culpabilização do indivíduo é retomado. Nesse caso, a Promoção da Saúde é tomada como forma de "controle social" (sutil e imperceptível) de populações específicas, consideradas "vulneráveis" e ao mesmo tempo "ameaças" (Stotz, Araújo, 2004).

O modelo sociocultural por sua vez é o mais abrangente e considera o contexto como responsável pelo comportamento desviante. Nesse caso, as práticas são direcionadas para transformação desse contexto e não a adequação dos sujeitos ao meio. Porém a perspectiva que se busca ainda é a abstinência, através da utilização de recursos que incorporam aspectos dos quatro modelos, numa metodologia mais moderna e com informações criteriosas e científicas, que dão maior credibilidade ao discurso.

Ascelrad (2005) apresenta ainda outras classificações e modelos de outros autores, mas que retomam essa classificação básica $^{6}$. Estes modelos preventivos são incorporados também às práticas dos trabalhadores de saúde quando confrontados com demandas relacionadas ao consumo de drogas. Nota-se que os entrevistados, ao elaborarem as práticas voltadas aos usuários de drogas, utilizam não apenas um modelo, mas fragmentos de dois ou mais modelos para configurar os discursos e as práticas, principalmente os modelos jurídico moral e da saúde pública, que são atinentes ao paradigma proibicionista. O contexto de miséria e desigualdade social, presentes na realidade do território onde vivem as pessoas atendidas por esses trabalhadores, é desconsiderado ou servindo apenas como pano de fundo na construção das práticas em

\footnotetext{
${ }^{6}$ Essa classificação dos modelos preventivos foi apresentada pela primeira vez na obra clássica da pesquisadora de Helen Nowlis, intitulada "A verdade sobre as drogas", no ano de 1975.
} 
saúde, de forma geral, e especificamente na construção das práticas voltadas para usuários de drogas (Soares, 2007).

Essa reflexão sobre a postura do trabalhador da saúde em relação ao consumo de drogas e o processo de produção dos serviços e das práticas direcionadas aos usuários de drogas é compartilhada por outros estudiosos na área como apontam Spricigo e Alencastre (2004), Barros e Pillon (2007) e Moretti-Pires et al (2011). Estes pesquisadores, ao analisarem as atitudes dos trabalhadores da $A B$ diante do fenômeno do consumo de drogas, mostram que estes apresentam uma postura positiva diante dos consumidores de drogas, apesar da prevalência em seus discursos de opiniões condenatórias e estigmatizantes. Como o atendimento aos usuários de drogas nesse nível de atenção é bastante restrito Barros e Pillon (2007) questionam esse posicionamento positivo.

As atitudes dos profissionais do PSF foram positivas em relação ao uso e aos usuários de drogas de maneira geral, quando comparadas com a escala original. Tais resultados podem ser considerados positivos, supondose que esteja havendo uma melhora geral de atitudes e aceitação por parte dos profissionais de saúde diante do usuário de drogas. Mas, em contrapartida, observa-se que outra hipótese a ser considerada é de o atendimento do dependente de álcool, por exemplo, ser tão desprovido de suporte na Rede Primária que o grupo, por motivos diversos, possui pouco contato com dependentes e acaba não desenvolvendo atitudes negativas pelo simples fato de não viver as dificuldades no tratamento (Barros, Pillon, 2007, p. 659).

O medo do trabalhador diante da ameaça ${ }^{7}$ do usuário de drogas, reflexo direto das concepções destes em relação aos sujeitos que consomem drogas, torna-se legítimo na relação entre

\footnotetext{
${ }^{7}$ Esta ameaça não é uma ameaça real e sim parte do imaginário social sobre o consumo de drogas, construída a partir de mecanismos que condicionam este imaginário a considerar apenas alguns enfoques do fenômeno com o intuito de promover o pânico social com uma função encobridora, instituindo um véu diante de problemas sociais mais incisivos e mais incômodos, relacionados, este sim, com a própria estruturação da sociedade e suas injustiças, suas intolerâncias perante as diferenças de pensamento e de estilos de vida, sua negação de direitos humanos básicos. (Bucher, 1996, p.49)
} 
estes sujeitos, reforçando o estigma e o preconceito dos trabalhadores e da sociedade diante do usuário de drogas.

Esse posicionamento estigmatizante dos profissionais de saúde da $A B$ diante dos usuários, refletido em seu discurso e nas suas práticas de forma implícita ou escancarada, gera uma intervenção também estigmatizante, que produz impactos negativos sobre as condições de vida e de saúde dessa população pois, em certa medida, estão afastando ainda mais os usuários de drogas dos serviços de $A B$.

Dessa primeira reflexão também podemos depreender o motivo que levam familiares e ACS, e não o próprio usuário de drogas, a buscar ajuda nos serviços de $A B$, pois estes sujeitos, segundo a análise preconceituosa da maioria dos membros da sociedade, são desprovidos de cidadania, não são portadores de direitos sociais e não possuem discernimento sobre o que é bom ou ruim para a sua vida.

Os familiares, por sua vez, não carregam esse estigma tão marcado em seus corpos e na sua vida, mesmo sofrendo o processo de culpabilização social quando tem componentes que são usuários de drogas. Na equação de culpabilização/responsabilização social, além do usuário, a família também é incluída.

Já os ACS, considerados os elos entre a população do território e os serviços de $\mathrm{AB}$ e por conhecerem há mais tempo os pacientes com problemas relacionados ao uso de drogas e todo o ambiente que o cerca, provavelmente podem se sentir mais à vontade no contato com esses pacientes (Barros, Pillon, 2007, p.660). Essa proximidade exige dele uma postura de identificação e resolução da demanda (mesmo sendo um atendimento paliativo e focado no encaminhamento de tal demanda para outro profissional ou outro nível). Dependendo do nível de comprometimento do sujeito usuário de drogas, de sua família, e daqueles que estão em volta, o ACS não pode ficar alheio à situação de sofrimento apresentada (Barros, Pillon, 2007). Assim, esse trabalhador se sente na 
"obrigação" de tomar uma atitude, conforme relatos de alguns trabalhadores entrevistados.

Por outro lado, por conta de compartilharem das mesmas formas de produção e reprodução social e da proximidade com desfechos muitas vezes trágicos ligados ao consumo de drogas, os ACS são os que reproduzem, de forma mais enfática, as concepções do modelo jurídico-moral e de saúde pública em relação ao consumo de drogas, reforçando os estereótipos desfavoráveis que caracterizam os usuários de drogas. Esse processo é caracterizado em estudo de Lachtim (2010), que analisa os valores (que configuram as concepções sobre determinados fenômenos) de jovens de diferentes classes sociais. Em relação ao consumo de drogas, os jovens das regiões periféricas e quase periféricas (as mais pobres) é que reproduzem os discursos mais criminalizadores e condenatórios em relação ao consumo de drogas. Segundo a autora:

Entre as classes populares, reconhece-se o efeito das condições precárias de vida e trabalho sobre o dia-a-dia, mas raramente relaciona-se isso ao consumo de drogas, sendo incomum aos jovens expressarem consciência sobre a relação entre consumo de álcool, por exemplo, e incapacidade de obter renda para prover a família. O que eles sabem associar concretamente é o envolvimento com drogas ao ingresso na criminalidade, provavelmente porque quem usa drogas ilícitas está, de saída, cometendo um crime, mas não só, pois há muitas histórias de atos ilícitos sendo cometidos para pagar dívidas contraídas com o narcotráfico (...) Por isso, nas regiões periféricas, o problema remete à fatalidade e as soluções à cura da dependência já instalada, pelo tratamento, pela moral do trabalho e da disciplina, únicas saídas que parecem viáveis, aos olhos de quem vivem de perto as consequências do problema, para o envolvimento dos jovens com as drogas e com o tráfico nas periferias (Lachtim, 2010, p.211).

O consumo de drogas, especialmente de drogas ilícitas, é tratado pelos entrevistados como algo pejorativo, errado e exclusivamente prejudicial. Nesse aspecto eles também reproduzem conceitos do paradigma proibicionista, ao considerarem apenas 0 uso danoso e prejudicial de algumas substâncias em detrimento do 
uso prejudicial das substâncias lícitas e dos outros tipos de usos que são feitos das diferentes substâncias psicoativas ao longo da história da humanidade (Carneiro, 2002).

Até mesmo a classificação estritamente ideológica de drogas lícitas e ilícitas tem um caráter parcial, que desconsidera as descobertas e o conhecimento científico acerca das substâncias psicoativas, dos seus efeitos no organismo e os danos que estas substâncias podem causar (Carneiro, 2002; Nutt et al. 2007). Negligenciando esses conhecimentos, organismos internacionais classificam as substâncias em lícitas ou ilícitas e justificam essa classificação enviesada por conta do grau de periculosidade das mesmas, legitimando o discurso proibicionista e obliterando um debate sério e transparente em relação a essa classificação.

Os trabalhadores de saúde da $A B$ desta pesquisa reproduzem essa classificação, apresentando uma condenação explícita ao uso de substâncias ilícitas e uma certa tolerância em relação às drogas lícitas. Esse posicionamento dos trabalhadores e da sociedade, de uma forma geral, não permite que estes sujeitos enxerguem os danos do proibicionismo e os benefícios que poderiam advir de uma mudança nos rumos das políticas públicas sobre drogas.

Numa publicação do Transnational Institute, organização situada em Amsterdã e dedicada à pesquisa e promoção de diálogo na área de políticas de drogas no mundo, o cientista social alemão Martin Jelsma, coordenador do Programa Drogas e Democracia deste instituto, apresenta uma análise bastante provocativa sobre as propostas políticas inovadoras de alguns países no mundo.

Ao questionarem o posicionamento mundial de criminalização de algumas substâncias psicoativas, a partir de recentes estudos científicos, que contradizem as classificações hegemônicas sobre as drogas e de análises críticas e reflexivas sobre as consequências negativas do proibicionismo, estes países conseguiram construir propostas eficazes e mais condizentes com a realidade do consumo de drogas na atualidade e passaram a enfrentar de forma lúcida e 
objetiva os problemas decorrentes do proibicionismo, como o encarceramento em massa de jovens usuários de drogas e a falta de tratamento adequado para aquelas pessoas que desenvolvem uma relação destrutiva com as substâncias psicoativas (Jelsma, 2009).

Porém, os trabalhadores de saúde, especialmente os da $A B$, não têm acesso a esse tipo de reflexão e continuam mais permeáveis às concepções hegemônicas e de senso comum sobre o fenômeno do consumo de drogas, reproduzindo, de um lado, discursos de maior tolerância em relação às drogas lícitas e, de outro, discursos estritamente condenatórios em relação ao consumo de drogas ilícitas. Dessa forma, tentam conferir legitimidade a práticas limitadas de lidarem com o problema, sendo incapazes de qualificarem as demandas que chegam e ressignificá-las para ampliação do objeto de tais práticas.

As formas como são estruturados os processos de trabalho na $A B$ e como se dá a produção de serviços de saúde no país, aliadas às formas hegemônicas do setor saúde de considerar as formas de apresentação do fenômeno do consumo de drogas na atualidade não colaboram para que os profissionais de saúde, especialmente da $A B$, rompam com práticas estigmatizantes $e$ construam intervenções de forma a responder as necessidades dos sujeitos (sociais) que consomem drogas. Estes trabalhadores elencam como objeto de suas práticas (direcionadas aos usuários de drogas) apenas a dependência ou 0 consumo em si de determinadas substâncias psicoativas sendo que o sujeito dessas práticas passa a ser 0 doente ou 0 usuário de drogas fraco e vulnerável. Reproduzem em suas práticas, portanto, as concepções hegemônicas de objeto e sujeito de tais práticas (Santos et al, 2007).

Com este recorte limitado do objeto e sem acessar as necessidades de saúde dos sujeitos usuários de drogas, as práticas tornam-se restritas às intervenções clínicas ou de promoção da 
saúde $^{8}$, com o objetivo (não aparente) de controle das populações vulneráveis e excluídas, através de apartação social (aprisionamento ou internação) ou ações educativas voltadas apenas para mudança de comportamento e não para a transformação da realidade. Essas amarras institucionais e ideológicas aprisionam os trabalhadores a práticas de saúde vazias e inférteis no campo da assistência ao usuário de drogas.

As ideologias (construídas a partir dos interesses da classe dominante) que permeiam o fenômeno do consumo de drogas na sociedade não conseguem ser rompidas na educação formal dos distintos profissionais de saúde, uma vez que, a maioria dos espaços de formação está profundamente influenciada pelos modelos biomédico e psiquiátrico (Campos, Soares, 2004; MorettiPires et al, 2011).

Tais espaços deveriam promover, para além do ensino técnico, questionamentos das teorias e concepções hegemônicas e extrapolar a função de simples reprodutores de conhecimento para construtores de conhecimento crítico e conectado com a realidade social e com o contexto histórico. Porém, esses espaços, sob a égide do modo de produção capitalista neoliberal, apenas reproduzem e servem de legitimadores dos paradigmas dominantes (de forma geral e especialmente na área de drogas) como apontam estudos de Almeida, Soares (2002), Campos, Soares (2004) e Campos et al (2009) que avaliam o processo de ensino-aprendizado

\footnotetext{
${ }^{8}$ Stotz e Araújo (2004) fazem uma crítica bastante profunda em relação à Promoção da Saúde e o Empowerment. Eles trazem para a reflexão sobre o conceito de Promoção da Saúde aspectos como o autoritarismo das estratégias pautadas sob o enfoque desta política que pode ser vista como uma forma de tutela da maioria da população e questionam se o empowerment não configuraria como um dos instrumentos da hegemonia do Banco Mundial face à soberania limitada dos estados nacionais na periferia do mundo capitalista (Stotz, Araújo 2004 p. 15). Segundo estes autores: (...) de fato, consideramos que uma das mudanças relevantes na prática da saúde pública no Brasil, desde o advento da promoção, tenha sido a sofisticação das estratégias de culpabilização das próprias vítimas da incúria sanitária, além da creditação oficial das teorias do condicionamento comportamental (behaviorismo), absolutamente avessas a qualquer pedagogia da problematização. (Stotz, Araújo, 2004, p. 13)
} 
nas universidades, especificamente na área da enfermagem, podendo considerar pertinentes esses aspectos também nas outras áreas, aja visto os resultados deste estudo, que não apresentam diferenças significativas de compreensão do fenômeno do consumo de drogas entre os diferentes profissionais entrevistados.

O estudo de Campos e Soares (2004) atenta para o fato de que são pequenos os espaços críticos-reflexivos sobre o fenômeno de drogas nas universidades de enfermagem e apontam que:

A discussão acadêmica, que poderia dar elementos para que os estudantes tivessem melhores condições de avaliar a problemática do uso de drogas, parece estar obscurecida, prevalecendo noções distorcidas veiculadas pelos órgãos de comunicação e, muitas vezes, estabelecidas pela impossibilidade de acesso a reflexões teóricas ou críticas que beneficiariam a compreensão das experiências conhecidas. (Campos, Soares, 2004, p.105)

Os trabalhadores de saúde formados nessas escolas, que não proporcionam uma reflexão crítica sobre o fenômeno do consumo de drogas na contemporaneidade, trazem consigo uma bagagem teórica sobre drogas estritamente amarrada ao conceito psiquiátrico (que tem forte influência nessa construção ideológica do consumo de drogas como doença), patologizando a relação dos sujeitos com as substâncias psicoativas, principalmente as ilícitas (Campos, Soares, 2004; Moretti-Pires et al, 2011; Vannucchi, Carneiro Jr, 2012). Numa relação patológica com as drogas, o que a escola defende e ensina são apenas as intervenções puramente curativas. São apenas essas práticas, pautadas no modelo biomédico-psiquiátrico que o trabalhador da saúde aprende nos bancos escolares.

Não há possibilidade de se ampliar o objeto das práticas de saúde a partir de conhecimentos tão restritos e de uma ideologia fortemente associada à concepção estigmatizante do usuário de drogas e do próprio consumo de drogas (Campos, Soares, 2004).

Perspectivas inovadoras e potentes para ampliar o olhar sobre o fenômeno do consumo de drogas e promover o cuidado das 
pessoas que consomem drogas, de forma humana, digna e efetiva como a RD nem sequer aparecem nas falas e discursos dos trabalhadores, reflexo dessa formação limitada (Gonçalves, 2002; Spricigo, Alencastre, 2004; Spricigo et al, 2004; Barros, Pilon, 2007; Landi Filho et al, 2009).

Compreende-se aqui o porquê da redução do objeto do processo de trabalho destes sujeitos à doença e/ou à substância em si e não ao ser integral que está por trás desse consumidor de drogas e as suas necessidades. Com isso, as práticas (como observado na pesquisa) restringem-se à utilização de instrumentos estritamente clínicos (consultas individuais e encaminhamentos para consultas com outros trabalhadores) sem ampliação do objeto do processo de trabalho.

O Estado brasileiro, no enfrentamento das questões relacionadas ao consumo de drogas, segue o paradigma hegemônico do proibicionismo de determinadas substâncias, cerceando o debate lúcido sobre o fenômeno e seus aspectos contemporâneos como o narcotráfico e a violência, engendrados nessa problemática e muitas vezes analisados de forma enviesada (Rodrigues, 2003). Assim, as políticas públicas brasileiras na área de drogas seguem as políticas internacionais reafirmando em todo o aparato jurídico e político, direcionado ao enfrentamento do fenômeno do consumo de drogas, o ideário de "guerra ás drogas" (Karam, 2003, 2005).

O setor saúde somente nos últimos anos é que vem ocupando papel propositivo nessa área, uma vez que, historicamente ele participa de forma bem tímida na arena de disputas sobre as políticas públicas na área de drogas (Machado, Miranda, 2007). Ainda temos no país duas políticas públicas em vigor na área de drogas: a da SENAD, que acompanha a tendência mundial de enfocar a repressão à produção, comercialização e consumo de algumas substâncias e a do MS que enfoca o sujeito consumidor de drogas, como sendo um sujeito dotado de direitos, 
inclusive o direito de consumir substâncias psicoativas. Estas duas políticas hoje disputam espaço e legitimidade na arena política onde se discutem as questões relacionadas ao consumo de drogas. São nessas arenas que são construídas as diretrizes que definirão as formas como o Estado brasileiro enfrentará o fenômeno e onde serão investidos os recursos (Coelho et al, 2012).

Mesmo a participação mais efetiva do MS nessas arenas de disputa e os avanços trazidos pela política do MS para Atendimento Integral aos Usuários de Álcool e Outras Drogas estes não são potentes o suficiente para enfrentarem os interesses econômicos camuflados e as amarras ideológicas do proibicionismo, que cerceiam qualquer possibilidade de mudança política no país na área de drogas (mesmo com a crescente discussão promovida por alguns movimentos sociais sobre o tema). Também não são capazes de promover a ruptura com 0 modelo assistencial biomédico e psiquiátrico que limitam as práticas de saúde voltadas aos usuários de drogas na $A B$ e não ampliam o objeto do processo de trabalho para além da doença ou do desviante. Em última instância, todos esses avanços não transformam a lógica de produção dos serviços de saúde direcionados aos usuários de drogas (Coelho et al, 2012)

Sendo as práticas dos trabalhadores direcionadas pelas políticas públicas e influenciadas pelo aparato jurídico e político do país, faz-se necessário refletir sobre as consequências destes aparatos, principalmente no processo de produção dos serviços de saúde.

A proibição de algumas drogas colabora para a inacessibilidade das demandas dos usuários de drogas não só nos serviços de saúde, mas nos demais espaços públicos. O estigma mais pesado e danoso ao usuário é aquele que o coloca "fora da lei", ou seja, o criminaliza de forma indiscriminada (Bastos, 2003; Karam, 2005). E lugar de criminoso não é no serviço de saúde, na rua, nos espaços de cultura, educação e lazer e sim na cadeia. Esse 
"pensamento" povoa o imaginário da sociedade, incluindo os trabalhadores de saúde.

Não há espaços de reflexão sobre as consequências destas leis e políticas, antiquadas e contraproducentes, nos espaços de trabalho e formação dos trabalhadores de saúde.

Fazendo uma análise das práticas dos profissionais de saúde da $A B$ fica nítido a influência marcante dessa característica proibicionista das leis e políticas no cotidiano dos trabalhadores, quando estes se defrontam com questões relacionadas ao consumo de drogas. As práticas são individuais, centrando aspectos negativos do consumo e priorizando a abstinência total. No caso das práticas educativas, o discurso terrorista predomina na forma de "palestra" e não de debate, reflexão ou conversa sobre o assunto (Acselrad, 2005). Tal assunto é elencado ao status de tabu e, por conta disso, não consegue ser debatido com clareza e objetividade. $O$ tema do consumo de drogas para os trabalhadores de saúde da $A B$ permanece amarrado ao paradigma proibicionista, que obscurece a reflexão com o discurso combativo de "guerra às drogas".

Alternativas ao atendimento restrito das demandas dos usuários de drogas, que se amparam na perspectiva da RD ampliada, como as experiências dos consultórios de rua (Jorge, Corradi-Webster, 2012), que promovem uma ampliação nas formas de compreender o fenômeno do consumo de drogas por parte dos trabalhadores, não encontra espaço nos serviços de $A B$.

Estes, de uma forma geral, desconhecem o conteúdo deste novo paradigma que se contrapõe ao paradigma hegemônico do proibicionismo, propondo uma outra ética para lidar com pessoas que fazem uso de drogas de forma prejudicial (Brites, 1999; Landi Filho et al, 2009). Em todos os estudos analisados sobre atendimento aos usuários de drogas na $A B$, não há referências dos trabalhadores sobre a $\mathrm{RD}$, corroborando com os dados encontrados nesta pesquisa (Gonçalves, 2002; Spricigo, Alencastre, 2004; Spricigo et al, 2004; Barros, Pilon, 2007; Landi Filho et al, 2009). 
Percebe-se que o aparato jurídico político e ideológico na área de drogas, que perpassa o tecido social como um todo (tendo seu arcabouço construído e legitimado pelo Estado), incluindo os espaços de formação dos trabalhadores em saúde e os processos de produção das intervenções em saúde, reproduzem o paradigma dominante de "guerra às drogas" e inevitavelmente influencia de forma negativa a produção de práticas direcionadas aos usuários de drogas. 

Considerasōes

Finais 



\section{CONSIDERAÇÕES FINAIS}

Com este estudo buscou-se alcançar o objetivo de analisar as práticas dos trabalhadores dos serviços de saúde da $A B$ voltadas para consumidores de drogas, a partir do levantamento dessas práticas junto a trabalhadores, utilizando-se a categoria analítica processo de trabalho.

O quadro teórico procurou localizar a complexidade do consumo de drogas na atualidade e expor os principais elementos que explicam a constituição de políticas públicas na área de drogas, tanto do ponto de vista das tendências internacionais de tratamento social ao problema do consumo de psicoativos, quanto do ponto de vista das políticas de saúde mais gerais que emanam do Estado brasileiro.

A finalidade foi a de promover uma denúncia sobre a ausência de práticas de saúde direcionadas aos usuários de drogas na $A B$, que contemplassem as necessidades de saúde desses sujeitos, visto que o pressuposto construído com a análise da bibliografia na área encaminhou nessa direção.

Dessa forma, além de trazer à tona os elementos do processo de trabalho, expondo-se o objeto, os meios e instrumentos, o trabalho em si e a organização do trabalho, quando a atenção voltase para o usuário de drogas, foi possível lançar o olhar sobre as potencialidades da $A B$ para lidar com o consumo prejudicial de drogas nos territórios da UBS e desenvolver propostas de transformar as práticas atuais em instrumentos de acolhimento das demandas e de levantamento ativo de necessidades de uma população estigmatizada e escondida.

Para percorrer este caminho crítico-reflexivo foi necessário, inicialmente, identificar como as demandas relacionadas ao consumo de drogas chegavam até os serviços de $A B$, quais eram os caminhos e descaminhos dessas demandas dentro e fora da rede de 
serviços de saúde, especificamente na $A B$, e como os profissionais de saúde lidavam com tais demandas no seu cotidiano de trabalho.

A partir daí, foi possível analisar e refletir sobre aspectos que facilitavam e/ou dificultavam o acesso dessas demandas e, por conseguinte, os fatores que afastavam ou aproximavam os usuários de drogas, seus familiares e suas demandas dos serviços de $A B$.

Em todo o processo analítico, o referencial teórico foi tomado como norte no direcionamento das questões a serem observadas e nas reflexões feitas, a partir da realidade empírica. As políticas públicas direcionadas aos usuários de drogas e também aquelas que organizam os processos de produção dos serviços de saúde na $A B$ e, por conseguinte, o sistema de saúde brasileiro, conforme comentando anteriormente, permearam as considerações, uma vez que, esse arcabouço político desenha as possibilidades e as formas de lidar com determinados fenômenos na realidade concreta dos serviços de saúde.

No que concerne à atenção ao usuário de drogas na $A B$, é possível afirmar que a estrutura do processo de produção dos serviços de saúde, na qual os trabalhadores de saúde se inserem, é sustentada por aspectos políticos e ideológicos, que reiteram concepções reducionistas sobre o consumo e sobre o consumidor de drogas. Dessa forma, concebem um objeto de atenção fora do escopo da $A B$, já que o dependente de drogas, problema recortado como objeto da atenção em saúde como um todo, supostamente seria atendido em espaços especializados. Em outras palavras, o consumidor de drogas, tomado unicamente na sua condição de doente, não seria objeto dos processos de trabalho nesse nível de atenção. Assim, quando o problema se aproxima ele é visto como anômalo para aquele espaço, de maneira que, com "boa vontade", são tomados alguns encaminhamentos e decisões, de forma muito precária e frágil, que não promovem transformações sobre os potenciais de desgaste e fortalecimento que estão mediando a estrutura social e os desfechos de consumo prejudicial de drogas. 
Elencaremos abaixo as questões que vieram à tona neste estudo e que possibilitaram a reflexão:

1) Por conta da forma como se configura atualmente o trabalho no setor saúde, influenciado pelos modelos tayloristasfordistas e toyotista, ao profissional da saúde na $A B$ dificilmente se colocam possibilidades de refletir sobre 0 processo de trabalho do qual participam e, muito menos, sobre os aspectos relacionados ao processo de produção dos serviços de saúde como um todo, que, em última instância, é o que desenha o modelo assistencial vigente. Assim 0 trabalho desse agente não é o trabalho coletivo, que interrelaciona os diferentes processos de trabalho dentro de um serviço de saúde com objetivo de transformar os perfis epidemiológicos dos grupos sociais, prevalecendo o trabalho parcelar, fragmentado e mecânico e que não corresponde às necessidades de saúde da população atendida.

2) $O$ modelo assistencial vigente não rompe com o modelo biomédico e privatista, comprometendo assim as formas de produção das práticas em saúde. Os trabalhadores inseridos nesse modelo assistencial não produzem práticas a partir do reconhecimento das necessidades de saúde da população que vive e trabalha no território da UBS, pois os instrumentais disponíveis para esse trabalhador não permitem que estes resignifiquem as demandas que chegam a estes serviços. Tais práticas, especialmente aquelas relacionadas ao consumo de drogas, são construídas a partir da demanda espontânea e de normas e fluxogramas desenvolvidos em níveis centrais, sem que os profissionais de saúde "da ponta" tenham acesso.

3) As políticas públicas na área da saúde, de forma geral, e na área de drogas especificamente, que determinam o modelo assistencial que conformará a produção dos serviços de saúde nas diferentes áreas são resultado de embates gerenciais e pouco permeáveis aos interesses coletivos da 
população que será assistida nesses serviços e dos trabalhadores que executam essas políticas. Assim, perpetuase um modelo assistencial que responde aos interesses privados e dominantes daqueles que concebem saúde como mercadoria.

4) $O$ neoliberalismo, com a sua força ideológica, imprime ao setor saúde, alterações significativas nos processos de produção dos serviços de saúde, desconsiderando todas as conquistas e avanços do SUS.

5) A droga, inserida numa realidade globalizada e permeada pela lógica do modo de produção capitalista, é uma mercadoria de grande rentabilidade. Porém, a sociedade constrói sua explicação sobre o consumo de drogas a partir de interesses, que reproduzem ideologicamente conceitos cristalizados, que colocam na substância psicoativa uma força capaz de sobrepujar a sociedade, e no usuário de drogas a incapacidade de fazer frente a essa dominação.

6) Nesse sentido, toda a força ideológica do proibicionismo, que direciona as explicações sobre a dinâmica social das drogas, também determina as bases explicativas do profissional da saúde sobre o fenômeno. Assim, a partir de modelos como o jurídico-moral e o da saúde pública esses trabalhadores vão moldando sua compreensão sobre o fenômeno, e, a partir daí, construindo as intervenções de saúde direcionadas àqueles que consomem drogas de maneira prejudicial.

7) A formação dos trabalhadores da área da saúde é eminentemente técnico-clínica, o que não ajuda a romper com as amarras ideológicas do proibicionismo, do modelo assistencial biomédico e da mercadorização da saúde. Temos então profissionais de saúde na $A B$ com formação insuficiente e/ou inadequada para apreender e lidar com fenômenos complexos como o consumo de drogas. 
8) Quando uma demanda relacionada ao consumo de drogas consegue vencer as dificuldades impostas pela forma como se organizam os processos de produção dos serviços de saúde e ultrapassar as barreiras ideológicas do estigma e do preconceito, chegando finalmente ao serviço de $A B$, ela encontra um trabalhador despreparado para produzir práticas que tenham potencial de responder às necessidades de saúde que estão por trás dessas demandas, que muitas vezes já chegam cristalizadas, e não são reinterpretadas por esses profissionais de saúde. Os aspectos ideológicos que tendem a culpabilizar o usuário são dominantes e os meios e instrumentos disponíveis para esse trabalhador são inadequados para que este recorte o objeto do processo de trabalho de forma ampla e possa captar as necessidades de saúde.

9) As práticas que são produzidas a partir de objeto simplificado e reduzido tendem a ser simplistas e pouco favorecem mudanças significativas, que impactariam de forma positiva sobre as formas dos sujeitos se relacionarem com as drogas, perpetuando representações de senso comum sobre 0 problema.

10) A ausência de espaços críticos de reflexão e formação está na base de problematização pobre sobre os processos de trabalho, os processos de produção de saúde e sobre a questão do consumo de drogas. Torna-se dessa forma difícil, superar concepções hegemônicas, que emanam de paradigmas hegemônicos e das formas como a formação social contemporânea se organiza.

A partir da análise dos aspectos acima mencionados percebese que os trabalhadores de saúde da $A B$ sofrem, muitas vezes de forma difusa e pouco concreta e objetiva, a influência de aspectos superestruturais que condicionam os valores em sociedade. Essa influência pode ser percebida na reflexão que fazem sobre o 
fenômeno do consumo de drogas; sua bagagem teórica é incapaz de ampliar a teia explicativa do fenômeno do consumo de drogas. No plano estrutural mais concreto, que amolda o processo de produção de serviços de saúde, pode-se verificar a amarração feita pelos modelos assistenciais, que não parecem proporcionar ruptura com o modelo biomédico e privatista.

O quadro levantado mostra que, na situação analisada, é bastante difícil construírem-se práticas condizentes com as necessidades de saúde da população usuária de drogas.

\subsection{ALGUMAS CONSIDERAÇÕES SOBRE POSSÍVEIS ENCAMINHAMENTOS}

Para finalizar esta reflexão, é importante pensarmos propostas para que os trabalhadores da $A B$ promovam atenção aos sujeitos sociais que usam drogas de forma prejudicial que seja condizente com os princípios de universalidade, integralidade e equidade, que norteiam o SUS.

A formação dos trabalhadores de saúde e as práticas na $A B$ devem ser retomadas pelos propositores de políticas públicas no sentido de romper com:

- as formas hegemônicas de organização dos distintos processos de trabalho nos espaços sociais de produção de serviços de saúde;

- os modelos assistenciais que privilegiam o trabalho individualizado, desprezando a produção coletiva, e que disparam processos de trabalho sem que as necessidades de saúde sejam concretamente reconhecidas;

- as ideologias que encobrem a perversidade do modo de produção capitalista, que está na base do consumo atual de drogas.

Promover tais rupturas não constitui processo simples, mas, defendemos que o referencial teórico que embasa este estudo, tem potência para explicar a realidade e viabilizar este processo a partir 
da instrumentalização política dos trabalhadores e usuários de drogas.

Promover reflexão crítica e questionamento do status quo, tanto nos espaços formais de formação quanto nos espaços de trabalho torna-se imprescindível para a construção de uma rede de cuidado à população usuária de drogas organizada a partir da AB.

A partir desta instrumentalização, trabalhadores e usuários de drogas sentir-se-ão aptos e perceberão a importância estratégica de ocuparem as arenas decisórias, onde são construídas as políticas públicas que direcionam as ações do Estado frente ao fenômeno do consumo de drogas, bem como os espaços gerenciais que definem os processos de produção dos serviços de saúde.

A AB tem enorme potencial para ser o nível de atenção capaz de reestruturar a atenção ao usuário de drogas, uma vez que, é este nível que se encontra mais próximo da realidade concreta dos distintos grupos sociais que vivem nos territórios, onde concretamente se situam o fenômeno e os desfechos do consumo prejudicial de drogas. É preciso, portanto, que este nível de atenção não se mantenha mais alheio a este fenômeno. O Estado deve reconhecer esse potencial e investir na centralidade da $A B$ na construção do SUS e lócus fundamental para a implementação da atenção aos usuários de álcool e outras drogas. Para tanto, é necessário investir no trabalhador da $A B$ e reconhecer nele toda a potencialidade desse nível de atenção. 



\section{REFERÊNCIAS}

Abramides MBC, Cabral MSR. Regime de acumulação flexível e saúde do trabalhador. São Paulo em perspectiva. 2003; 17(1): 3-10.

Acselrad G. A Educação para a Autonomia: construindo um discurso democrático sobre as drogas. Rio de Janeiro: Ed. FIOCRUZ; 2005. Avessos do prazer: drogas, aids e direitos humanos; 183-212.

Almeida $\mathrm{AH}$, Soares $\mathrm{CB}$. A dimensão política do processo de formação de pessoal auxiliar: a enfermagem rumo ao SUS. Rev Latino-am Enfermagem. 2002; 10 (5): 629-636.

Althusser L. Sobre a Reprodução. Rio de Janeiro: Ed. Vozes; 1999.

Alves VS. Modelos de atenção à saúde de usuários de álcool e outras drogas: discursos políticos, saberes e práticas. Cad. Saúde Pública. 2009; 25(11): 2309-2319.

Andrade TM. $O$ nó da seringa. In: Bastos FI, Mesquita $F$, organizadores. Troca de seringas: drogas e Aids. Ciência, debate e saúde pública. Brasília: Coordenação Nacional de DST e Aids: Ministério da Saúde, 1998. p.153-161.

Antunes R. A era da informatização e a época da informalização: riqueza e miséria do trabalho no Brasil. São Paulo: Ed. Boitempo; 2006. Riqueza e miséria do trabalho no Brasil; 15-25.

Arretche M. A política da política de saúde no Brasil. In: Lima NT, Gerschman S, Edler FC, Suárez, JM, organizadores. Saúde e Democracia Histórias e perspectivas do SUS. Rio de Janeiro: Ed. FIOCRUZ, 2005. p. 285-306.

Baraldi S. Supervisão, flexibilização e desregulamentação no mercado de trabalho: antigos modos de controle, novas incertezas nos vínculos de trabalho da enfermagem [tese]. São Paulo: Escola de Enfermagem, Universidade de São Paulo; 2005.

Bardin L. Análise de conteúdo. Lisboa: Edições 70; 1977.

Baratta A. Introdução a uma sociologia da droga. In: Mesquita F, Bastos FI. Drogas e AIDS Estratégia de Redução de Danos. São Paulo: Ed. Hucitec, 1994.

Barros MA, Pillon SC. Atitudes dos profissionais do PSF diante do uso e abuso de drogas. Esc Anna Nery Rev Enferm. 2007; 11(4): 655-662. 
Bastos Fl. Redução de Danos e Saúde Coletiva: reflexões a propósito das experiências internacional e brasileira. In: In: Bastos FI, Karam ML, Martins SM. Drogas, dignidade \& inclusão social. A lei e a prática de Redução de Danos. Rio de Janeiro: ABORDA; 2003, p.15-41.

Bedinelli T. Próximo prefeito herdará sistema de saúde avaliado como o pior problema de SP. Folha de S. Paulo [periódico na internet]. 2012 set. 08 [citado 2012 nov. 02]. Disponível em: http://www1.folha.uol.com.br/poder/1150367-proximo-prefeitoherdara-sistema-de-saude-avaliado-como-o-pior-problema-desp.shtml.

Boron A. Os "Novos Leviatãs" e a polis democrática: neoliberalismo, decomposição estatal e decadência da democracia na América Latina. In: Gentili P, Sader E, organizadores. Pós-neoliberalismo II que Estado para que democracia? Petrópolis, RJ: Paz e Terra, 1999. p. 7-67.

Brasil. Ministério da Justiça. Secretaria Nacional sobre Drogas. SENAD. Crack, é possível vencer [homepage na Internet]. Brasília; 2012 [citado 2012 nov. 15]. Disponível em: http://www.brasil.gov.br/crackepossivelvencer/publicacoes/crack-epossivel-vencer-1/view.

Brasil. Ministério da Justiça. Secretaria Nacional sobre Drogas. Mapeamento das instituições governamentais e não-governamentais de atenção às questões relacionadas ao consumo de álcool e outras drogas no Brasil - 2006/2007. Brasília: UNB, 2007.

Brasil. Ministério da Saúde. Secretaria de Atenção à Saúde. Departamento de Atenção Básica. Política Nacional de Atenção Básica. Brasília; 2006.

Brasil. Gabinete de Segurança Institucional. Conselho Nacional Antidrogas. Política Nacional sobre Drogas. Brasília; 2005.

Brasil. Ministério da Saúde. Secretaria de Atenção à Saúde. SVS/CN-DST/AIDS. A Política do Ministério da Saúde para Atenção Integral a Usuários de Álcool e outras Drogas/Ministério da Saúde. 2.ed. rev. ampl.- Brasília: Ministério da Saúde, 2004.

Bravo MIS, Menezes JSB. Política de Saúde no Governo Lula. In: Bravo MIS, Pereira DS, Menezes JSB, Oliveira MMN, organizadoras. Política de saúde na atual conjuntura: Modelos de Gestão e Agenda para a Saúde. Rio de Janeiro: UERJ, Rede Sirius, 2007. p. 13-20. 
Brites CM. Uso de droga injetável e redes de integração social prazer e cuidados com a saúde, é possível? [dissertação]. São Paulo: PUC; 1999.

Bucher R, Oliveira SRM. O discurso do "combate às drogas" e suas ideologias. Rev. Saúde Pública. 1994; 28(2): 137-145.

Bucher, R. Drogas e sociedade nos tempos da Aids. Brasília: Universidade de Brasília; 1996.

Calipo SM, Soares, CB. Público e Privado na Reforma do Sistema de Saúde no Brasil. Sociedade em Debate. Dez/jan. 2008; 14(1): 119-138.

Campos FV, Soares CB. Conhecimento dos estudantes de enfermagem em relação às drogas psicotrópicas. Rev. esc. enferm. USP. 2004, 38 (1): 99-108.

Campos CMS, Mishima SM. Necessidades de saúde pela voz da sociedade civil e do Estado. Cad. Saúde Pública. Jul/ago. 2005; 21(4): $1260-1268$.

Campos CMS, Soares, CB, Trapé CA, Silva BRB, Silva TC. Articulação teoria-prática e processo ensino-aprendizagem em uma disciplina de Enfermagem em Saúde Coletiva. Rev Esc Enferm USP. 2009; 43(Esp2): 1226-1231.

Canoletti B, Soares CB. Programas de prevenção ao consumo de drogas no Brasil: uma análise da produção científica de 1991 a 2001. Interface-Comunic, saúde, educ. Set.2004/fev.2005; 9(16): 115-129.

Capistrano Filho D. O programa de saúde da família em São Paulo. Estudos Avançados. 1999; 13(35): 89-100.

Carneiro HS. As necessidades humanas e o proibicionismo das drogas no século XX. Outubro-Instituto de Estudos Socialistas. 2002; 6: 115-128.

Carneiro HS. O movimento proibicionista. In: Carneiro HS. Bebida, Abstinência e temperança na história antiga e moderna. São Paulo: Ed. SENAC São Paulo, 2010. p.193-206.

Chizzotti A. Pesquisa em ciências humanas e sociais. São Paulo: Cortez; 2010.

Coelho HV, Soares CB, Godoy A, Oliveira E, Campos CMS, Cordeiro L. Políticas públicas de saúde aos usuários de álcool e outras drogas: contribuição da Saúde Coletiva ao debate. Estácio de 
Sá - Ciências da Saúde. Rev da Faculdade Estácio de Sá. Goiânia SESES - GO. No prelo.

Costa DO, Tambellini AT. A visibilidade dos escondidos. Phisis Revista de Saúde Coletiva. 2009; 19(4): 953-968.

David HMSL, Mauro MYC, Silva VG, Pinheiro MAS, Silva FH. Organização do trabalho de e na Atenção Básica: Uma questão para a saúde do trabalhador. Texto Contexto Enferm. Abr/jun 2009; 18(2): 206-214.

Delfini PSS, Sato MT, Antoneli PP, Guimarães POS. Parceria entre CAPS e PSF: o desafio da construção de um novo saber. Ciência \& Saúde Coletiva. 2009; 14(Supl.1): 1483-1492.

Delgado PG. Drogas: O desafio da saúde pública. In: Acselrad G, organizadora. Avessos do prazer: drogas, aids e direitos humanos. Rio de Janeiro: Ed. FIOCRUZ, 2005. p. 165-181.

Dimenstein M, Severo AK, Brito M, Pimenta AL, Medeiros V, Bezerra E. O apoio matricial em Unidades de Saúde da Família: experimentando inovações em saúde mental. Saúde Soc. São Paulo. 2009; 18(1): 63-74.

Escorel S, Nascimento DR, Edler FC. As origens da Reforma sanitária e do SUS. In: Lima NT, Gerschman S, Edler FC, Suárez, JM, organizadores. Saúde e Democracia Histórias e perspectivas do SUS. Rio de Janeiro: Ed. FIOCRUZ, 2005. p. 59-81.

Favoreto CAO, Camargo Jr. KR. Alguns desafios conceituais e técnico-operacionais para o desenvolvimento do Programa de Saúde da Família como uma proposta transformadora do modelo assistencial. PHYSIS: Rev. Saúde Coletiva. 2002; 12(1):59-75.

Fonseca EM, Bastos FI. Política de Redução de Danos em perspectiva: Comparando as experiências americana, britânica e brasileira. In: Acselrad G. Avessos do prazer: Drogas, AIDS e Direitos Humanos. Rio de Janeiro: Ed. FIOCRUZ, 2005. p. 289-310.

Frente Nacional Contra a Privatização da Saúde. Contra fatos não há argumentos que sustentem as Organizações Sociais no Brasil: Relatório analítico de prejuízos à sociedade, aos trabalhadores e ao erário por parte das Organizações Sociais. São Paulo: Fórum Popular de Saúde; 2011.

Giovanella L, Mendonça MHM, Almeida PF, Escorel S, Senna MCM, Fausto MCR et al. Saúde da família: limites e possibilidades para uma abordagem integral de atenção primária à saúde no Brasil. Ciência \& Saúde Coletiva. 2009; 14(3):783-794. 
Gonçalves AM. Cuidados diante do abuso e da dependência de drogas: desafio da prática do Programa de Saúde da Família. [tese]. Ribeirão Preto: Escola de Enfermagem de Ribeirão Preto, Universidade de São Paulo, 2002.

Gonçalves SSPM, Tavares CMM. Atuação do enfermeiro na atenção ao usuário de álcool e outras drogas nos serviços extra-hospitalares. Esc Anna Nery Rev Enferm. 2007; 11(4): 586-592.

Heimann LS, Mendonça MH. A trajetória da Atenção Básica em Saúde e do Programa de Saúde da Família no SUS: Uma busca de identidade. In: Lima NT, Gerschman S, Edler FC, Suárez, JM, organizadores. Saúde e Democracia Histórias e perspectivas do SUS. Rio de Janeiro: Ed. FIOCRUZ, 2005. p. 481-502.

Heimann LS, Ibanhes LC, Boaretto RC, Castro IEN, Telesi Jr. E, Cortizo CT et al. Atenção primária em saúde: um estudo multidimensional sobre os desafios e potencialidades na Região Metropolitana de São Paulo (SP, Brasil). Ciência \& Saúde Coletiva. 2011; 16(6): 2877-2887.

Jelsma M. Legislative Innovation in Drug Policy: Latin American Initiative on Drugs and Democracy. Amsterdã:Transnational Institute (TNI), 2009.

Jorge JS, Corradi-Webster CM. Consultório de Rua: Contribuições e Desafios de uma Prática em Construção. Sau. \& Transf. Soc. 2012; 3(1): 39-48.

Karam ML. Legislação Brasileira sobre Drogas: história recente - a criminalização da diferença. In: Acselrad G, organizadora. Avessos do prazer: drogas, aids e direitos humanos. Rio de Janeiro: Ed. FIOCRUZ, 2005. p. 155-164.

Karam ML. Redução de danos, ética e lei: os danos da política proibicionista e as alternativas compromissadas com a dignidade do indivíduo. In: Bastos FI, Karam ML, Martins SM.Drogas, dignidade \& inclusão social. A lei e a prática de Redução de Danos. Rio de Janeiro: ABORDA, 2003. p.45-97.

Lacaz FAC. Qualidade de vida no trabalho e saúde/doença. Ciência \& Saúde Coletiva. 2000; 5(1): 151-161.

Lachtim SA. Jovens de Santo André, SP, Brasil: um estudo sobre valores em diferentes grupos sociais [dissertação]. São Paulo: Universidade de São Paulo; 2010. 
Landi Filho D, Araújo ODS, Cavalcante RO, Mendes SS, Miranda Júnior UJP. Redução de danos e saúde da família: conhecimento de profissionais de saúde em três regionais do DF/Brasil. Com. Ciências Saúde. 2009; 20(4): 299-306.

Machado AR, Miranda PSC. Fragmentos da história da atenção à saúde para usuários de álcool e outras drogas no Brasil: da Justiça à Saúde Pública. História, Ciências, Saúde. 2007; 14(3): 801-821.

Marques F, Doneda D. A política brasileira de Redução de Danos pelo uso indevido de drogas: Diretrizes e seus desdobramentos nos estados e municípios. In: Bastos FI, Mesquita F, organizadores. Troca de seringas: drogas e Aids. Ciência, debate e saúde pública. Brasília: Coordenação Nacional de DST e Aids: Ministério da Saúde, 1998. p. 137-152.

Minayo MCS. Ciência, técnica e arte: $O$ desafio da pesquisa social. In: Minayo MCS, organizadora. Pesquisa Social: teoria, método e criatividade. Petrópolis,RJ: Ed.Vozes; 1994.

Minayo MCS. O desafio do conhecimento. Pesquisa qualitativa em saúde. São Paulo: Ed. Hucitec; 2004.

Ministério da Saúde. Portaria n. 545, de 20 maio de 1993. Estabelece normas e procedimentos reguladores do processo de descentralização da gestão das ações e serviços de saúde, através da Norma Operacional Básica - SUS 01/93. Diário Oficial União, Brasília, 1993.

Ministério da Saúde. Portaria n. 2.203, de 05 novembro de 1996. Redefine o modelo de gestão do Sistema Único de Saúde, constituindo, por conseguinte, instrumento imprescindível à viabilização da atenção integral à saúde da população e ao disciplinamento das relações entre as três esferas de gestão do Sistema, através da Norma Operacional Básica - SUS 01/1996. Diário Oficial União, Brasília, 1996.

Moretti-Pires RO, Corradi-Webster CM, Furtado EF. Consumo de Álcool e Atenção Primária no Interior da Amazônia: sobre a Formação de Médicos e Enfermeiros para Assistência Integral. Revista Brasileira de Educação Médica. 2011; 35(2): 219-228.

Munari DB, Melo TS, Oliveira MB, Barbosa CC, Queiroz ACCM, Araújo BFM. Capacitação de agentes comunitários de saúde para o cuidado em saúde mental na atenção básica: potencializando pessoas para cuidar de pessoas. Rev Tempus Actas Saúde Colet. 2010; 4(1): 115-123. 
Noronha JC, Soares LT. A política de saúde no Brasil nos anos 90. Ciência \& Saúde Coletiva. 2001; 6(2): 445-450.

Nunes IM, Moura MAV, Amâncio Filho A, Telles JL. O trabalho em saúde no contexto hospitalar: Processos e necessidades como subsídios para a formação profissional. Esc Anna Nery R Enferm. 2006; 10(3): 509-513.

Nutt D, King LA, Saulsbury W, Blakemore C. Development of a rational scale to assess the harm of drugs of potential misuse. Lancet. 2007; 369: 1047-1053.

Passos EH, Souza TP. Redução de Danos e Saúde Pública: Construções alternativas à política global de "Guerra às Drogas". Psicologia \&Sociedade. 2011; 23(1): 154-162.

Peduzzi M. Mudanças tecnológicas e seu impacto no processo de trabalho em saúde. Trabalho, Educação e Saúde. 2002; 1(1): 75-91.

Queiroz VM, Salum MJL. Reconstruindo a intervenção da Enfermagem em Saúde Coletiva. [Documento produzido da revisão do texto inédito apresentado ao $48^{\circ}$ Congresso Brasileiro de Enfermagem]. São Paulo: Escola de Enfermagem, Universidade de São Paulo; 1996.

Rezende CAP. O Modelo de Gestão do SUS e as ameaças do Projeto Neoliberal. In: Bravo MIS, Pereira DS, Menezes JSB, Oliveira MMN, organizadoras. Política de saúde na atual conjuntura: Modelos de Gestão e Agenda para a Saúde. Rio de Janeiro: UERJ, Rede Sirius, 2007. p. 26-42.

Ribeiro EM, Pires D, Blank VLG. A teorização sobre processo de trabalho em saúde como instrumental para análise do trabalho no Programa Saúde da Família. Cad, Saúde Pública. 2004; 20 (2): 438446.

Rodrigues T. Narcotráfico: uma guerra na guerra. São Paulo: Editora Destino/Série Elementos; 2003.

Rossi D, Pawlowicz MP, Zunino D. Acessibilidad de los usuarios de drogas a los servicios públicos de salud em lãs ciudades de Buenos Aires y Rosario: La perspectiva de los trabajadores de la salud. Buenos Aires: Intercambios Asociación Civil; 2007.

Salum MJL, Queiroz VM, Soares CB. Pesquisa social em saúde: Lições gerais de metodologia. A elaboração do plano de pesquisa como momento particular da trajetória teórico-metodológica. [Documento pedagógico de orientação aos alunos de Metodologia 
de Investigação em Saúde Coletiva]. São Paulo: Escola de Enfermagem, Universidade de São Paulo; 1999.

Salum MJL, Queiroz VM. Saúde e trabalho: um exercício de reconhecimento dos potenciais/processos de desgaste e de fortalecimento. [Texto sistematizado para subsidiar o desenvolvimento da aula sob o tema Saúde do Trabalhador, ministrada em 02/04/1998 no Curso de Especialização em Enfermagem em Centro Cirúrgico. Editado e revisto em 2005]. São Paulo: Escola de Enfermagem, Universidade de São Paulo; 2005.

Santos VC. A relação trabalho-saúde dos enfermeiros do PSF da região de Vila Prudente-Sapopemba: um estudo de caso [dissertação]. São Paulo: Escola de Enfermagem, Universidade de São Paulo; 2007.

Santos VC, Soares CB, Campos CMS. A relação trabalho-saúde de enfermeiros do PSF no município de São Paulo. Rev Esc Enferm USP. 2007; 41(esp): 777-781.

Santos VE. O objeto/sujeito da redução de danos: uma análise da literatura da perspectiva da saúde coletiva [dissertação]. São Paulo: Escola de Enfermagem, Universidade de São Paulo; 2008.

São Paulo (cidade). Secretaria Municipal da Saúde (SMS) [homepage na Internet]. São Paulo: PRODAM; 2012. [citado 2012 nov. 30]. Disponível em: http://www.capital.sp.gov.br/portalpmsp/

Scherer MDA, Marino SRA, Ramos FRS. Rupturas e resoluções no modelo de atenção à saúde: reflexões sobre a estratégia de saúde da família com base nas categorias kuhnianas. Interface-Comunic, Saúde, Educ. Set.2004/fev2005; 9(16): 53-66.

Schraiber LB, Mendes-Gonçalves RB. Necessidades de Saúde e Atenção Primária. In: Schraiber LB, Nemes MIB, Mendes-Gonçalves RB, organizadores. Saúde do Adulto: Programas e ações na Unidade Básica. Série Saúde em Debate. São Paulo: Ed. Hucitec; 1996.

Seixas PHD. As organizações sociais de saúde em São Paulo, 19982001: Uma visão institucional [dissertação]. São Paulo: Escola de Administração de Empresas de São Paulo, Fundação Getúlio Vargas; 2003.

Shimizu HE, Carvalho Jr. DA. O processo de trabalho na Estratégia Saúde da Família e suas repercussões no processo saúde-doença. Ciência \& Saúde Coletiva. 2012; 17(9): 2405-2414.

Silva SM. A unidade de redução de danos do município de Santo André: Uma avaliação [dissertação]. São Paulo: Escola de Enfermagem, Universidade de São Paulo; 2008. 
Silveira DP, Vieira ALS. Saúde mental e atenção básica em saúde: análise de uma experiência no nível local. Ciência \& Saúde Coletiva. 2009; 14(1): 139-148.

Soares BM, Rohden F. As melhores intenções: Análise dos programas de prevenção e recuperação da dependência química. Rio de Janeiro: Núcleo de Pesquisa/ISER; 1994.

Soares CB, Jacobi PR. Adolescentes, drogas e AIDS: avaliação de um programa de prevenção escolar. Cad. Pesqui. Mar 2000; 109: 213-237.

Soares CB, Salvetti MG, Ávila LK. Opinião de escolares e educadores sobre saúde: o ponto de vista da escola pública de uma região periférica do município de São Paulo. Cad Saúde Pública. 2003; 19(4): 1153-1161.

Soares CB. Consumo contemporâneo de drogas e juventude: A construção do objeto na perspectiva da Saúde Coletiva [tese livre docência]. São Paulo: Escola de Enfermagem, Universidade de São Paulo; 2007.

Soares CB, Campos CMS, Leite AS, Souza CLL. Juventude e consumo de drogas: Oficinas de instrumentalização de trabalhadores de instituições sociais, na perspectiva da saúde coletiva. Interface Comunicação Saúde Educação. Jan/Mar. 2009; 13(28): 189-199.

Soares CB, Campos CMS, Berto JS, Pereira EG. Avaliação de ações educativas sobre consumo de drogas e juventude: a práxis no trabalho e na vida. Trab. Educ. Saúde. Mar/jun. 2011; 9(1): 43-62.

Sousa MF, Hamann EM. Programa de Saúde da Família no Brasil: uma agenda incompleta? Ciência \& saúde Coletiva. 2009; 14(Supl. 1): 1325-1335.

Spricigo JS, Alencastre MB. O enfermeiro de unidade básica de saúde e o usuário de drogas - um estudo em Biguaçú-SC. Rev Latino-am Enfermagem. Mar/abr. 2004; 12(número especial):427-32.

Spricigo JS, Carraro TE, Cartana MHF, Reibnitz KS. Atenção ao usuário de drogas - Um espaço para o enfermeiro. Texto Contexto Enferm. Abr/jun. 2004; 13(2): 296-302.

Stotz EN, Araújo JWG. Promoção da Saúde e Cultura Política: a reconstrução do consenso. Saúde e Sociedade. Mai/ago 2004; 13(2): 5-19. 
Teixeira CF, Paim JS, Vilasbôas AL. SUS, Modelos Assistenciais e Vigilância da Saúde. [Texto elaborado para a Oficina de Vigilância em Saúde do IV Congresso Brasileiro de Epidemiologia]. IESUS, VII (2); Abr/jun,1998.

Trad LAB, Rocha AARM. Condições e processo de trabalho no cotidiano do Programa de Saúde da Família: Coerência com princípios da humanização em saúde. Ciência \& Saúde Coletiva. 2011; 16(3): 1969-1980.

Trapé CA, Soares CB. A prática educativa dos Agentes Comunitários de Saúde à luz da categoria Práxis. Rev Latino-am Enfermagem. Jan/Fev. 2007; 15(1).

Triviños ANS. Introdução à pesquisa em Ciências Sociais: a pesquisa qualitativa em educação. São Paulo: Atlas; 1987.

Vannucchi AMC, Carneiro Jr N. Modelos tecnoassistenciais e atuação do psiquiatra no campo da atenção primária à saúde no contexto do Sistam Único de Saúde, Brasil. Physis Revista de Saúde Coletiva. 2012; 22(3): 963-982.

Vecchia MD, Martins STF. Desinstitucionalização dos cuidados a pessoas com transtornos mentais na atenção básica: aportes para a implementação de ações. Interface Comunicação Saúde Educação. Jan/mar. 2009; 13(28): 151-164.

Viana NA. Constituição das Políticas Públicas. Revista Plurais/UEG. 2006; 1(4): 94-112.

Vianna MLTW. O culpado é o mordomo? Constrangimentos outros (que não os do modelo econômico) à seguridade social. In: Lobato LVC, Fleury S, organizadoras. Seguridade Social, Cidadania e Saúde. Rio de Janeiro: CEBES; 2009. 


\section{ANEXOS}

\section{ANEXO 1 \\ Parecer do CEP/EEUSP}

Plataforma Brasil - Ministério da Saúde

Escola de Enfermagem da Universidade de São Paulo - EEUSP

PROJETO DE PESQUISA

Título: A Atenção ao usuário de drogas em Unidade Básica de Saúde: Um estudo de caso

Pesquisador: Heloisa da Veiga Coelho_ Versão: 1

Instituição: Escola de Enfermagem da Universidade de São ～CAAE: 00738012.6.0000.5392 Paulo - EEUSP

PARECER CONSUBSTANCIADO DO CEP

Número do Parecer: 5888

Data da Relatoria: $13 / 03 / 2012$

Apresentaçäo do Projeto:

Projeto de Pesquisa de Heloisa da Veiga Coelho, aluna Programa de Pós-Graduação em Enfermagem em Saúde Coletiva da Escola de Enfermagem da USP, sob orientação da Professora Doutora Cássia Baldini Soares. Não consta se é referente a dissertação de mestrado ou tese de doutorado.

Pesquisa qualitativa, de natureza descritiva, do tipo estudo de caso a ser desenvolvida em uma Unidade Básica de Saúde (UBS) do municipio de São Paulo. A UBS conta com seis equipes de saúde da familia, que cobrem aproximadamente $90 \%$ da população de abrangência da Unidade. Além dos profissionais da Estratégia de Saúde da Familia (ESF) há profissionais de saúde que atendem no modelo assistencial tradicional que "assistem aos usuários" que se encontram fora da cobertura do PSF. A UBS conta ainda com uma equipe de Núcleo de Apoio à Saúde da Família (NASF). Os sujeitos de pesquisa serão os profissionais de saúde que atuam na ESF, os profissionais que atuam no modelo tradicional e os usuários do serviço de saúde que foram atendidos na referida Unidade trazendo (direta ou indiretamente) como demanda a questão do uso de drogas. Os dados serão coletados a partir de entrevistas semi-estruturadas com seis profissionais da ESF, um profissional do NASF, três profissionais de saúde do modelo tradicional e seis usuários da UBS que apresentaram demandas relacionadas ao consumo de drogas. As entrevistas gravadas serão realizadas com base em roteiros, mediante o consentimento dos sujeitos da pesquisa e após serão transcritas na integra. Será realizada análise temática a partir de categorias de análise previamente determinadas. O Termo de Consentimento Livre e Esclarecido é objetivo, claro e o cronograma compativel com a viabilização do projeto.

Objetivo da Pesquisa:

Objetivo Primário

- Analisar as práticas voltadas para consumidores de drogas nos serviços de Atenção Básica (AB) em saúde, tomando por referência as políticas públicas de saúde brasileiras nessa área.

Objetivos Secundários:

- Levantar as práticas atuais voltadas para pessoas que fazem uso de drogas nos serviços de $A B$;

- Identificar como as questões relacionadas ao consumo de drogas chegam aos serviços de AB e transformamse em demandas:

- Apreender como os profissionais de saúde lidam com essas demandas no cotidiano do trabalho; - Analisar a tendência dessas práticas frente às políticas públicas voltadas para usuários de drogas. Avaliaçäo dos Riscos e Benefícios:

As pesquisadoras afirmam que a pesquisa em questão não apresenta nenhum risco para o pesquisador nem para os sujeitos que eventualmente participarem do estudo.

Como benefícios indicam:

- Produção de conhecimento numa área que apresenta poucos estudos com natureza crítica e propositiva - Auxilio na elaboração de políticas públicas mais condizentes com a realidade vivida por usuários de drogas e profissionais de saúde que atuam na porta de entrada do sistema de saúde e que se deparam cotidianamente com situações realcionadas direta ou indiretamente com o fenômeno do consumo de drogas na contemporaneidade;

- Proposição de reflexão sobre o fenômeno do consumo de drogas para os profissionais de saúde da $A B$ - Denunciar a falta de atendimento adequado das demandas relacionadas ao consumo de substâncias psicoativas na $\mathrm{AB}$ e

- Apontar a importância da $\mathrm{AB}$ na configuração da rede de atendimento aos usuários de drogas do municipio. 
Heloisa da Veiga Coelho

como os profissionais de saúde lidam com tais questões no cotidiano do seu trabalho e quais são os

desdobramentos desse atendimento na vida de algumas pessoas que chegam até a unidade trazendo

problemas relacionados ao consumo de drogas lícitas ou ilicitas.

As proponentes esperam promover uma denúncia sobre a ausência de atendimento adequado, resolutivo e

eficiente, para pessoas que fazem uso de drogas e/ou seus familiares e que chegam nas UBS.

Também intencionalizam propor aos gestores e aos profissionais de saúde da $\mathrm{AB}$ uma reflexão sobre o

fenômeno do consumo de substâncias psicoativas na contemporaneidade, iluminada pelo paradigma da Saúde

Coletiva, que propõe uma Redução de Danos ampliada. Por fim, evidenciam que o estudo poderá fornecer

informaçốes sobre qual é o papel da AB frente à questão do consumo de drogas na contemporaneidade.

Consideraçóes sobre os Termos de apresentação obrigatória:

Recomendaçöes:

Em um dos arquivos do Projeto de Pesquisa constam 4 objetivos específicos e em outro são apresentados três

objetivos secundários. Parece que em um destes arquivos o segundo e terceiro objetivos foram transformados em

um único, contudo qual dos arquivos deverá ser considerado?

Conclusôes ou Pendências e Lista de Inadequaçōes:

Corrigir os objetivos especificos do projeto, pois em um dos arquivos constam três e noutro quatro.

Considero que após está correção o Projeto poderá ser APROVADO.

Situação do Parecer:

Aprovado

Necessita Apreciaçäo da CONEP:

Não

Consideraçöes Finais a critério do CEP:

Respondeu as solicitações deste CEP. Projeto aprovado.

06 de Março de 2012

Assinado por.

Celia Maria Sivalli Campos 


\section{ANEXO 2 \\ Parecer do CEP/PMSP}

\section{SÄO PAULO}

SECRETARIA MUNICIPAL DA SAÚDE

Comitê de Ética em Pesquisa/SMS

CAAE: 0012/12*

São Paulo, 05 de julho de 2012 PARECER N ${ }^{\circ} 113 / 12-$ CEP/SMS

IIma. Sra.

Heloisa de Veiga Coelho

Projeło de Pesquisa: A atenção ao usuário de drogas em Unidade Básica de Saúde: Um estudo de caso

Pesquisador Responsável: Heloisa de Veiga Coelho

Instituição: Escola de Enfermagem da universidade de São Paulo- EEUSP

Local onde os dados serāo coletados: UBS Dr. Eduardo romano Reschilian,

Patrocinador: a própria pesquisadora

\section{1 - Sumário Geral do Protocolo}

O fenômeno do uso de drogas pela sociedade é algo intrínseco à mesma e aparece em diversos espaços sociais, especialmente nos serviços de $A B$, porém o discurso hegemônico sobre o fenômeno do consumo de drogas na contemporaneidade reforça aspectos farmacológicos das substâncias criminalizando as consideradas ilicitas e culpabiliza o indivíduo que faz uso de drogas, considerando esse consumidor como "doente", "frágil"ou "desviante". A hegemonia deste discurso afeta diretamente os profissionais de saúde que atuam na $A B$, pois tal discurso encontra-se arraigado na sociedade nas políticas públicas de saúde. A Política do Ministério da Saúde para Atenção Integral a Usuários de Álcool e outras Drogas propōe o rompimento com a visão hegemônica do consumo de drogas pela sociedade e a revisão dos modelos assistenciais vigentes no país para conseguir contemplar as reais necessidades da população que faz uso de drogas. Para isso propōe, em consonância com a Lei da Reforma Psiquiátrica, a construção de uma rede de atenção comunitária que engloba: dispositivos extra-hospitalares (CAPS-Ad) e busca ativa e sistemática das demandas de uma população estigmatizada e escondida. Para a implementação real dessa rede é necessário que a AB seja incluida e participe ativamente, uma vez que, o MS reconhece a abrangência limitada dos CAPS Ad e a necessidade de capilaridade dessa rede, através dos serviços de AB para a criação de formas variadas de acesso a essa rede e qualificação das demandas.

Está é uma pesquisa de mestrado, que pretende, com seu resultado: a) denunciar a ausência de atendimento adequado, resolutivo e eficiente, para pessoas que fazem uso de drogas e/ou seus familiares que chegam às Unidades Básicas de Saúde e b) fornecer informaçōes sobre o papel da $A B$ frente à questão do consumo de drogas na contemporaneidade e c) levar os gestores e os profissionais de saúde da $A B$ a refletirem sobre o fenômeno do consumo de substâncias psicoativas ng contemporaneidade, sob o paradigma da Saúde Coletiva, que propōe uma Redução de Danos ampliada.

Para compreender como a rede de atenção às pessoas que fazem uso de álcool e outras drogas está se configurando no município de São Paulo e como são as práticas voltadas para essa população na $\mathrm{AB}$ é que se propõe este estudo. A escolha da unidade de saúde não se deu de forma aleatória. Foi escolhida a Unidade Básica de Saúde Dr. Eduardo Romano Reschilian como campo deste estudo, por que a pesquisadora já atuou como enfermeira da Estratégia de Saúde da Familia neste serviço por aproximadamente 4 anos, o que the permite partir de conhecimento aprofundado tanto sobre a realidade das necessidades de saúde dos grupos que vivem na área de abrangência da unidade como sobre os processos de trabalho em vigor na UBS.

A coleta sistemática de dados permitirá revelar como as questōes sobre o consumo de drogas chegam até as Unidades Básicas de Saúde, como os profissionais de saúde lidam com tais questões no cotidiano do seu trabalho e por último conhecer os desdobramentos deste atendimento na vida de algumas pessoas que chegaram até a unidade trazendo problemas relacionados ao consumo de drogas lícitas ou ilícitas. 


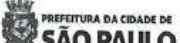

\section{SECRETARIA MUNICIPAL DA SAÚDE Comitê de Ética em Pesquisa/SMS}

CAAE: $0012 / 12 *$

Trata-se de uma pesquisa qualitativa, de natureza descritiva, do tipo estudo de caso, a ser reallzada apenas em uma Unidade Básica de Saúde do município de Sāo Paulo. Esta unidade conta com seis equipes de saúde da família, que cobrem aproximadamente $90 \%$ da população de abrangência da unidade.

Além dos profissionais da ESF há profissionais de saúde que atendem no modelo assistencial tradicional. Estes assistem aos usuários que se encontram fora da cobertura do PSF. A UBS conta ainda com uma equipe de NASF. A Organizaçāo Social (OS) que administra a unidade desde 2001 é a SPDM. Os sujeitos de pesquisa serão os profissionais de saúde que atuam na Estratégia de Saúde da
Família (ESF), os profissionais que atuam no modelo tradicional e os usuários do serviço de saúde que foram atendidos na unidade de saúde trazendo (direta ou indiretamente) como demanda a questão do uso de drogas.

Os dados serão coletados a partir de entrevistas semi-estruturadas com seis profissionais da ESF, um profissional do NASF, três profissionais de saúde do modelo tradicional e seis usútrios da UBS que apresentaram demandas relacionadas aO Consumo de drogas. As entrevistas seró reachas com base em roteiros e todas as entrevis pesquisa e após serão transcritas na íntegra. Será realizada análise temática, a partir de categorias de análise previamente determinadas.

\section{A pesquisa terá duas fases:}

Exploratória em que serão realizadas reuniōes (previamente agendadas) com cada uma das equipes de PSF e com a equipe do NASF parq apresentaçāo do projeto de pesquisq e para que membros das equipes, após solicitação da pesquisadora, apresentem, exemplos de casos e demandas relc (ícitas ou ilicitas que eles atenderam ou que acompanham nos últimos meses.

Todos os casos discutidos durante as reuniōes serão analisados posteriormente a partir dos prontuários, para identificar mais precisamente como a questão do consumo de drogas foi trazida e quais foram as condutas tomadas pela equipe e/ou pelo profissional de saúde que atendeu a demanda.

Nessas reuniões serāo identificados os profissionais de saúde que possuem interesse e afinidade com a temática em estudo e os usuários (um de cada equipe) que serão convidados a participar do estudo.

Os profissionais de saúde que não atuam no PSF serão convidados a participar do estudo e o farāo conforme seu interesse.

Serão realizadas entrevistas semi-estruturadas (anexos 1 e 2) com seis profissionais da ESF, um profissional do NASF, três profissionais de saúde do modelo tradicional e seis usuários da UBS que apresentaram demandas relacionadas ao consumo de drogas, selecionados na etapa anterior.

O local da entrevista será aquele que seja mais cômodo para os sujeitos da pesquisa. Todas as inserções do pesquisador no campo de estudo e suas impressões serāo registradas em um diário de campo para complementação dos dados.

\section{2 - Consideraçōes.}

A Folha de Rosto está corretamente preenchida, o currículo do pesquisador responsável está de acordo com a proposta da pesquisa. Cronograma e orçamento detalhado estão adequados. A pesquisadora informa que a coleta de dados não foi iniciada, incluindo-se a que se refere aos prontu ários, e só será iniciada mediante a aprovação deste Comitêt

Há tratamento adequado dos dados/informaçōes.

A metodologia é adequada aos objetivos, impõe certa condição de desconforto ao sujeito da pesquisa, porém tal condição encontra-se devidamente justificada no desenho da pesquisa.

Os direitos fundamentais do sujeito de pesquisa estão garantidos (informação, privacidade, recusa inócua, desistência, indenização, ressarcimento, continuidade do atendimento, acesso ao pesquisador e CEP, etc.).

- Termo de Consentimento Livre e Esclarecido (TCLE) adequado após correções.

* Rua General Jardim, 36 - ${ }^{\circ}$ andar - V. Buarque - fone: 3397.2464 - email: smscep@gmail.com

http://www.prefeitura.sp.gov.br/cidade/secretarias/saude/comite_de_etica/ 
CAAE: $0012 / 12^{*}$

3 - Situação do Prołocolo - Aprovado

Antes do inicio da coleta de dados, alertamos para a necessidade de contato com o gerente da unidade quando não foi ele quem autorizou a realização da pesquisa.

O sujeito de pesquisa (ou seu representante) e o pesquisador responsável deverão rubricar todas as folhas do Termo de Consentimento Livre e Esclarecido - TCLE apondo sua assinatura na última página do referido Termo, conforme Carta Circular no 003/2011 da CONEP/CNS.

Salientamos que o pesquisador deve desenvolver a pesquisa conforme delineada no protocolo aprovado. Eventuais modificaçōes ou emendas ao protocolo devem ser apresentadas ao CEP de forma clara e sucinta, identificando a parte do protocolo a ser modificada e suas justificativas.

Ao pesquisador cabe manter em arquivo, sob sua guarda, por 5 anos, os dados da pesquisa, contendo fichas individuais e todos os demais documentos recomendados pelo CEP (Res. CNS 196/96 item IX. 2. e)

Orelatório final deve ser apresentado ao CEP, logo que o estudo estiver concluído. 



\section{APÊNDICES}

\section{APÊNDICE A}

Roteiro de entrevista dos trabalhadores de saúde com os objetivos de cada pergunta (em negrito)

\section{Parte 1 - Apresentação}

- Idade - Captar dado demográfico, que em certa medida identifica experiência de vida.

- Formação - Identificar a formação profissional do trabalhador

- Trajetória profissional - Descrever a trajetória de inserção no trabalho no sentido de conhecer as experiências profissionais e suas especificidades, além de identificar a relação atual com a $A B$, bem como fatores que levaram esse trabalhador para a $A B$.

- Na sua formação e/ou trajetória profissional você teve alguma formação para atendimento das questões relacionadas ao consumo de drogas? - Conhecer o tipo de formação que o trabalhador teve na área de drogas.

- Se sim, fale-me sobre essa formação.

- Como essa temática foi abordada no seu curso de graduação? - Conhecer o tipo de formação que a educação formal proporcionou sobre drogas.

- Você conhece a política do Ministério da Saúde para a atenção integral a usuários de álcool e outras drogas? Identificar o conhecimento e a formação do trabalhador sobre políticas públicas, especificamente a política do MS de atenção aos usuários de drogas.

Observe-se que no decorrer das entrevistas esta pergunta foi retirada do roteiro por não colaborar na identificação da participação política dos trabalhadores e apenas constranger 
o trabalhador que na maioria das vezes desconhecia essa e outras políticas públicas.

\section{Parte 2 - Demanda}

- Você atende, no cotidiano do seu trabalho, pessoas que fazem uso de alguma droga? - Identificar se as demandas relacionadas ao consumo de drogas chegam à $A B$.

- É uma demanda muito significativa no cotidiano do seu trabalho? - Identificar a relevância dessas demandas no cotidiano dos serviços de $A B$ e no cotidiano do trabalhador.

- Como essas pessoas chegam até o serviço de saúde (sozinhas, ou trazidas pelos familiares ou ACS)? - Identificar as formas como essas demandas chegam à $A B$.

- Existem outras formas através das quais demandas relacionadas ao consumo de drogas chegam até você? Como? - Levantar se os trabalhadores conseguem identificar essa demanda específica a partir de outras demandas que chegam e são mais comuns no cotidiano de trabalho.

- Você já teve algum problema ou dificuldade para atender esse tipo de demanda? - Identificar aspectos que podem trazer dificuldade para 0 atendimento das demandas relacionadas ao consumo de drogas e se estes são percebidos pelos trabalhadores como preconceito, estigma e discriminação.

- Como a temática do consumo de drogas é discutida na sua equipe? E na UBS? - Identificar como as equipes e a UBS lidam com essas demandas no cotidiano do serviço. Qual é abordagem que este serviço de saúde tem em relação às demandas relacionadas ao consumo de drogas.

- Você acha que a demanda do consumo de drogas deva fazer parte das ações e programas (atendimento sistematizado) da 
UBS? De que forma? - Identificar a percepção dos trabalhadores sobre as restrições de atendimento proveniente das formas como se organizam os processos de trabalho na $A B$ e o processo de produção dos serviços de saúde como um todo.

\section{Parte 3 - Atendimento}

- Quando pessoas que fazem uso de drogas ou demandas dessa natureza chegam até você ou até a equipe quais são as condutas que você ou a equipe tomam? - Identificar o que é tomado como objeto do processo de trabalho quando a demanda a ser atendida está relacionada ao consumo de drogas.

- O atendimento realizado tem continuidade? Os usuários continuam frequentando a UBS? - Identificar se o atendimento às demandas relacionadas ao consumo de drogas é apenas pontual ou desencadeia intervenções capazes de oferecer respostas adequadas e resolutivas para os sujeitos que buscam ajuda.

- Nos atendimentos que faz você costuma perguntar aos usuários da UBS se eles usam drogas? - Identificar se a busca ativa por demandas relacionadas ao consumo de drogas fazem parte do cotidiano dos trabalhadores e compreender os motivos que colaboram para a execução dessa busca ativa.

- Como você avalia que tem sido a resolutividade das condutas tomadas por você ou por sua equipe em relação ao atendimento de pessoas com consumo prejudicial de drogas? - Identificar a percepção dos trabalhadores sobre as práticas direcionadas aos usuários de drogas.

- Há algum trabalho de prevenção ao consumo prejudicial de drogas desenvolvido pela equipe ou na unidade? - Identificar práticas direcionadas à prevenção do consumo 
prejudicial de drogas na unidade e sobre quais referenciais se apoiam.

- Se sim, descreva esse trabalho.

- Quais os resultados que a equipe ou a unidade tem conseguido? Identificar se há avaliação sobre a atenção à saúde ao usuário de drogas, e quais são as críticas realizadas. 


\section{APÊNDICE B}

\section{Termo de consentimento livre e esclarecido}

Meu nome é Heloisa da Veiga Coelho. Sou estudante do Programa de Pós-Graduação na área de Enfermagem em Saúde Coletiva da Escola de Enfermagem da Universidade de São Paulo.

Estou desenvolvendo uma pesquisa intitulada "A atenção ao usuário de drogas em Unidade Básica de Saúde: um estudo de caso".

Convido você a participar deste estudo que tem como objetivo analisar as práticas voltadas para consumidores de drogas nos serviços de Atenção Básica em saúde.

Os resultados deste estudo poderão contribuir para o aprimoramento da rede de assistência à população que faz uso de drogas, por meio de políticas públicas mais eficazes e condizentes com as necessidades dessa população estigmatizada e a realidade dos serviços de saúde.

Pedirei que me conceda uma entrevista com duração de aproximadamente 60 minutos, para conversarmos sobre 0 atendimento de pessoas com problemas relacionados ao consumo de drogas que procuram a Unidade Básica de Saúde.

Solicitarei sua autorização para que eu possa gravar a entrevista, que será transcrita em seguida.

Gostaria de esclarecer que sua participação no estudo é voluntária e que não será cobrado nada por ela, assim como não haverá remuneração financeira caso você participe.

Esclareço ainda que você poderá me pedir mais informações a respeito do estudo a qualquer momento e que tem todo o direito de se recusar a participar da pesquisa, inclusive podendo abandoná-la quando desejar, mesmo após a realização da entrevista, sem que isso lhe traga prejuízos de qualquer espécie. 
Não será necessário que se identifique. O seu anonimato e o sigilo dos dados confidenciais serão mantidos por ocasião da divulgação dos resultados da pesquisa em eventos e/ou periódicos.

Este termo será elaborado em duas vias e você receberá uma cópia na íntegra, assinada e com os meus contatos.

Se você estiver esclarecido(a) e concordar em participar do estudo, peço que preencha e assine a seção que se segue.

Desde já agradeço sua colaboração.

São Paulo, de de 2012.

Heloisa da Veiga Coelho

Telefone: (11)6361-0338 email: helocoelho@usp.br

Assinatura do entrevistado

Caso você tenha alguma dúvida, o telefone do Comitê de Ética em Pesquisa da Escola de Enfermagem da USP é (11) 3061-7548 e o email é edipesq@usp.br 